Prepared in cooperation with the Bureau of Reclamation

\title{
Occurrence, Distribution, and Transport of Pesticides in Agricultural Irrigation-Return Flow from Four Drainage Basins in the Columbia Basin Project, Washington, 2002-04, and Comparison with Historical Data
}

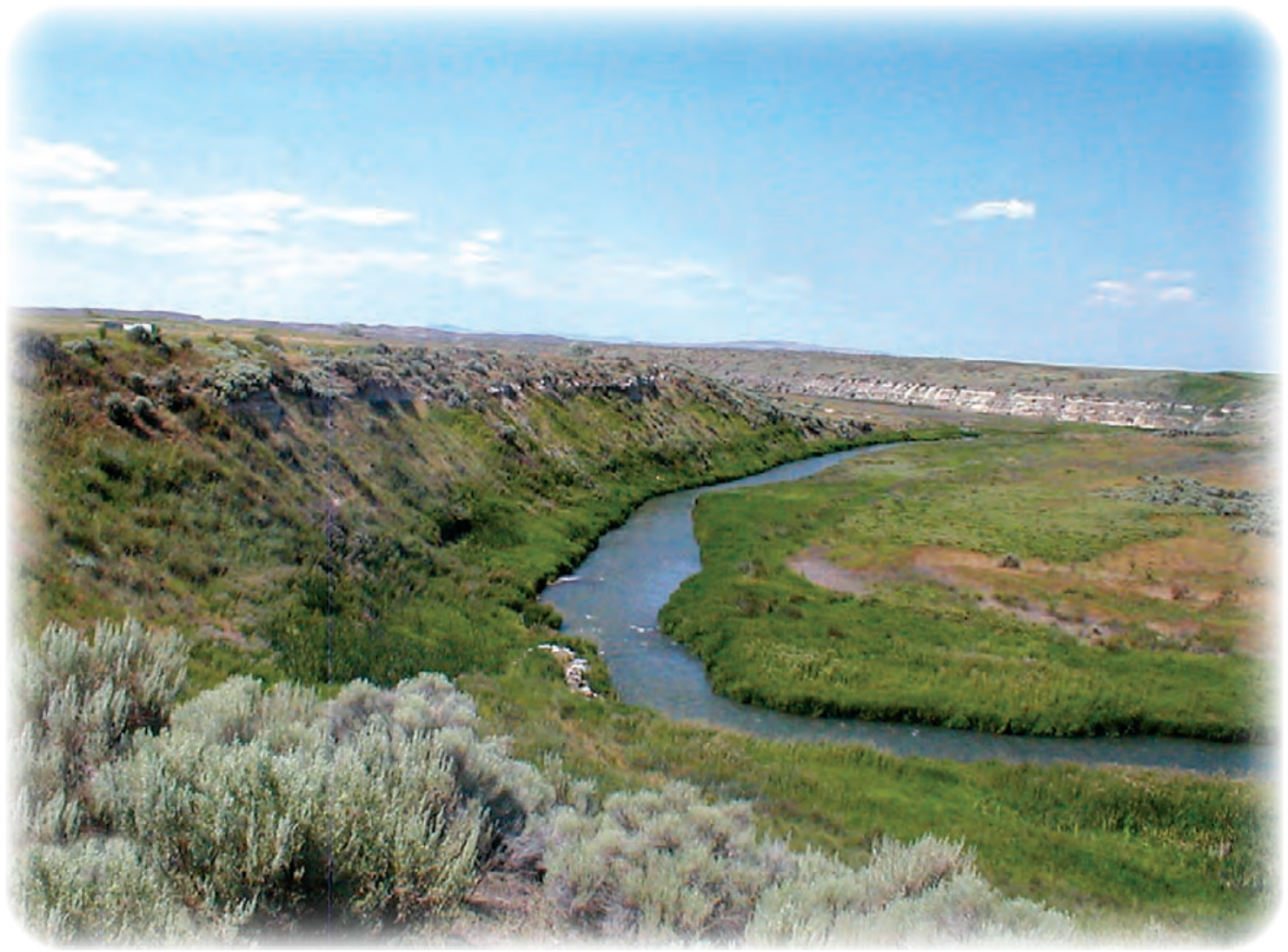

Scientific Investigations Report 2006-5005 
Cover: Photograph of Lind Coulee near Warden, Washington, about 1 mile west of State Route 17, looking downstream, July 2004.

(Photograph taken by Richard Wagner, U.S. Geological Survey.) 


\section{Occurrence, Distribution, and Transport of Pesticides in Agricultural Irrigation-Return Flow from Four Drainage Basins in the Columbia Basin Project, Washington, 2002-04, and Comparison with Historical Data}

By Richard J. Wagner, Lonna M. Frans, and Raegan L. Huffman

Prepared in cooperation with the

Bureau of Reclamation

Scientific Investigations Report 2006-5005 


\title{
U.S. Department of the Interior \\ Gale A. Norton, Secretary \\ U.S. Geological Survey \\ P. Patrick Leahy, Acting Director
}

\section{U.S. Geological Survey, Reston, Virginia: 2006}

\author{
For sale by U.S. Geological Survey, Information Services \\ Box 25286, Denver Federal Center \\ Denver, CO 80225 \\ For more information about the USGS and its products: \\ Telephone: 1-888-ASK-USGS \\ World Wide Web: http://www.usgs.gov/
}

\footnotetext{
Any use of trade, product, or firm names in this publication is for descriptive purposes only and does not imply endorsement by the U.S. Government.

Although this report is in the public domain, permission must be secured from the individual copyright owners to reproduce any copyrighted materials contained within this report.

Suggested citation:

Wagner, R.J., Frans, L.M., and Huffman, R.L., 2006, Occurrence, distribution, and transport of pesticides in agricultural irrigation-return flow from four drainage basins in the Columbia Basin Project, Washington, 2002-04, and comparison with historical data: U.S. Geological Survey Scientific Investigations Report 2006-5005, 54 p.
} 


\section{Contents}

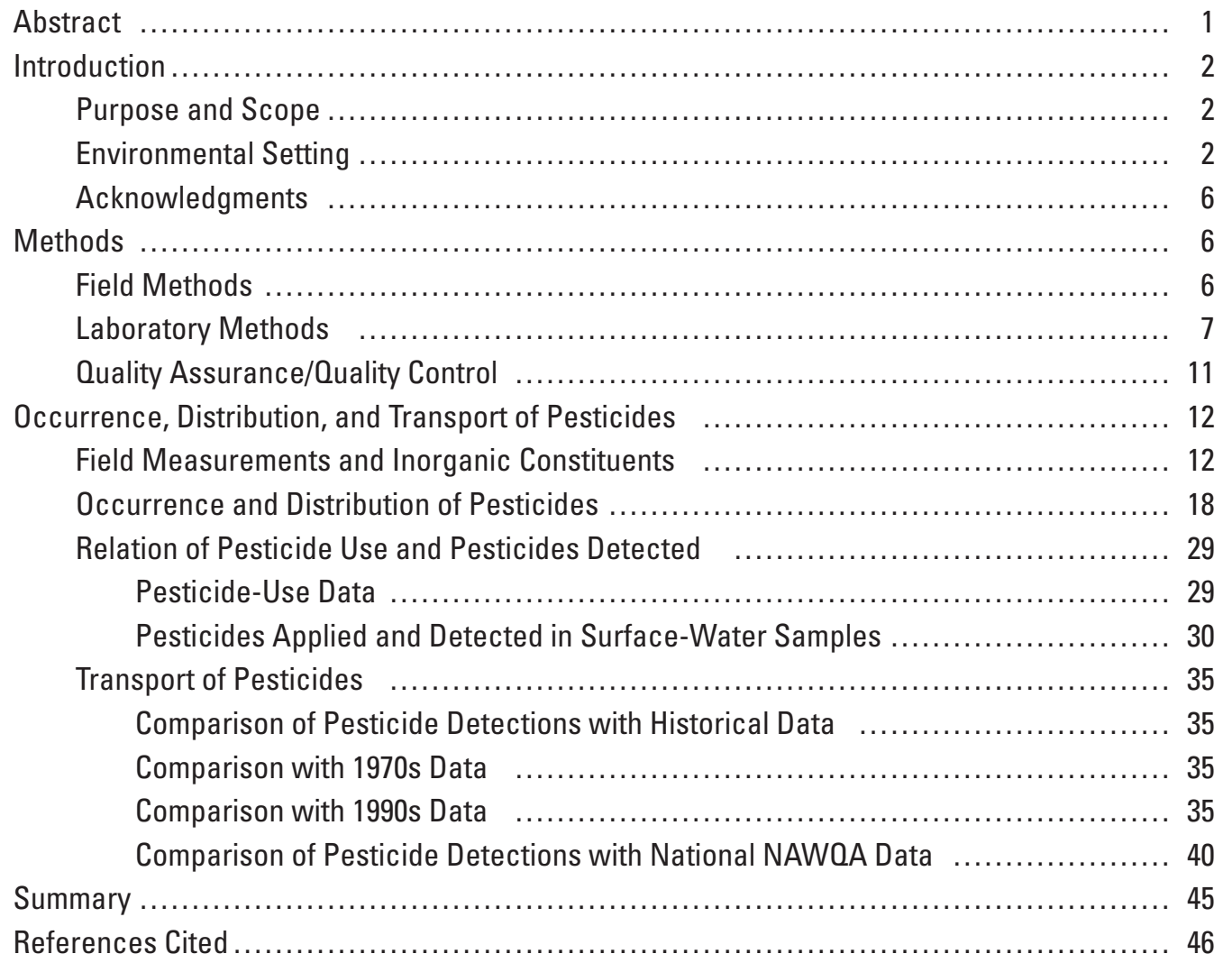




\section{Figures}

Figure 1. Map showing locations of the four irrigation return-flow drainage basins and surface-water sampling sites, Columbia Basin Project, Washington

Figure 2. Graph showing concentrations of dissolved solids in the four irrigation return-flow drainage basins, Columbia Basin Project, Washington, July 2002 to October 2004

Figure 3. Piper diagram showing percentage of major ions in surface water from the Columbia River and from the four irrigation return-flow drainage basins,

Columbia Basin Project, Washington

Figure 4. Graphs showing pesticide concentrations in four irrigation return-flow drainage basins, Columbia Basin Project, Washington, July 2002 to October 2004

Figure 5. Graphs showing pesticide-application rates and percentage of surface-water samples with pesticide detections in the four irrigation return-flow drainage basins, Columbia Basin Project, Washington, July 2002 to October 2004

Figure 6 Boxplots showing comparison of historical and current pesticide concentrations in the Crab Creek and Sand Hollow irrigation return-flow drainage basins, Columbia Basin Project, Washington ....

Figure 7. Graphs showing concentrations of simazine and terbacil in the Lind Coulee irrigation return-flow drainage basin, Columbia Basin Project, Washington, 1994 to 2004

Figure 8. Graphs showing comparison of selected pesticide concentrations in the Columbia Basin Project, Washington, July 2002 to October 2004 with national NAWQA concentrations

Figure 9. Graphs showing concentrations of nitrate plus nitrite and atrazine in samples from streamflow-gaging stations in the four irrigation return-flow drainage basins, Columbia Basin Project, Washington, July 2002 to October 2004

\section{Tables}

Table 1. Physical and land-use characteristics of the four irrigation return-flow drainage basins sampled for pesticides, Columbia Basin Project, Washington, July 2002 to October 2004

Table 2. Crop acreage estimates in the four irrigation return-flow drainage basins, Columbia Basin Project, Washington, 2003

Table 3. Inorganic and organic analytes and schedules, analytical methods, and references

Table 4. Pesticide target analytes, laboratory reporting levels, drinking water standards or guidelines, and aquatic-life benchmarks

Table 5. Summary of field measurements and concentrations of inorganic constituents in surface-water samples collected from the four irrigation return-flow drainage basins, Columbia Basin Project, July 2002 through October 2004 


\section{Tables-Continued}

Table 6. Summary of calculated major ion ratios in surface-water samples collected from the four irrigation return-flow drainage basins, Columbia Basin Project, and the Columbia River, Washington, July 2002 to October 2004

Table 7. Maximum concentrations and number of pesticide detections in the four irrigation return-flow drainage basins, Columbia Basin Project, Washington, July 2002 to October 2004

Table 8. Summary of pesticide concentrations in the four irrigation return-flow drainage basins, Columbia Basin Project, Washington, July 2002 to October 2004

Table 9. Summary of pesticide toxicity values for freshwater fish in the Columbia Basin Project, Washington

Table 10. Herbicides applied to irrigation canals, roads, and rights of way along irrigation canals, drains, and return flows in the four irrigation return-flow drainage basins, Columbia Basin Project, 2003.

Table 11. Estimated application for residential use of non-agricultural pesticides detected in water samples from the four irrigation return-flow drainage basins, Columbia Basin Project, Washington, July 2002 to October 2004

Table 12. Pesticides with no reported residential or major agricultural use detected in water samples from the four irrigation return-flow drainage basins, Columbia Basin Project, Washington, July 2002 to October 2004

Table 13. Detection rates of pesticides analyzed during the 1970s and from July 2002 to October 2004 in Crab Creek and Lind Coulee irrigation return-flow drainage basins, Columbia Basin Project, Washington

Table 14. Detection rates of pesticides analyzed for during the 1990s and from July 2002 to October 2004 in the Crab Creek, Lind Coulee, and Sand Hollow irrigation return-flow drainage basins, Columbia Basin Project, Washington

Table 15. Physical and chemical properties of pesticides frequently detected in four irrigation-return flow drainage basins in the Columbia Basin Project, Washington, July 2002 to October 2004

Table 16. Concentrations and precision data for pesticide replicate samples, Columbia Basin Project, Washington, July 2002 to October 2004

Table 17. Percentage of mean recoveries from field-matrix-pesticide analyses, Columbia Basin Project, Washington, July 2002 to October 2004

Table 18. Pesticide concentrations analyzed by gas chromatography/mass spectrometry and high-performance liquid chromatography/mass spectrometry, Columbia Basin Project, Washington, July 2002 to October 2004

Table 19. Registration status of pesticides analyzed, Columbia Basin Project, Washington, July 2002 to October 2004

Table 20. Summary of pesticides not detected, Columbia Basin Project, Washington, July 2002 to October 2004 


\section{Conversion Factors and Datums}

Conversion Factors

\begin{tabular}{lcl}
\hline Multiply & By & To obtain \\
\hline acre & 4,047 & square meter \\
acre & 0.001562 & square mile \\
cubic foot per second $\left(\mathrm{ft}^{3} / \mathrm{s}\right)$ & 0.02832 & cubic meter per second \\
foot (ft) & 0.3048 & meter \\
inch (in.) & 2.54 & centimeter \\
liter (L) & 33.82 & ounce, fluid \\
mile (mi) & 1.609 & kilometer \\
pound, avoirdupois $(\mathrm{lb})$ & 0.4536 & kilogram \\
square mile $\left(\mathrm{mi}^{2}\right)$ & 2.590 & square kilometer \\
\hline
\end{tabular}

Temperature in degrees Celsius $\left({ }^{\circ} \mathrm{C}\right)$ may be converted to degrees Fahrenheit $\left({ }^{\circ} \mathrm{F}\right)$ as follows:

$$
{ }^{\circ} \mathrm{F}=\left(1.8 x^{\circ} \mathrm{C}\right)+32 \text {. }
$$

Specific conductance is given in microsiemens per centimeter at 25 degrees Celsius $(\mu \mathrm{S} / \mathrm{cm}$ at $\left.25^{\circ} \mathrm{C}\right)$.

Concentrations of chemical constituents in water are given either in milligrams per liter (mg/L) or micrograms per liter ( $\mu \mathrm{g} / \mathrm{L})$.

Datum

Horizontal coordinate information is referenced to the North American Datum of 1927 (NAD27) and North American Datum of 1983 (NAD83). 


\title{
Occurrence, Distribution, and Transport of Pesticides in Agricultural Irrigation-Return Flow from Four Drainage Basins in the Columbia Basin Project, Washington, 2002-04, and Comparison with Historical Data
}

\author{
By Richard J. Wagner, Lonna M. Frans, and Raegan L. Huffman
}

\section{Abstract}

Water-quality samples were collected from sites in four irrigation return-flow drainage basins in the Columbia Basin Project from July 2002 through October 2004. Ten samples were collected throughout the irrigation season (generally April through October) and two samples were collected during the non-irrigation season. Samples were analyzed for temperature, $\mathrm{pH}$, specific conductance, dissolved oxygen, major ions, trace elements, nutrients, and a suite of 107 pesticides and pesticide metabolites (pesticide transformation products) and to document the occurrence, distribution, and pesticides transport and pesticide metabolites.

The four drainage basins vary in size from 19 to 710 square miles. Percentage of agricultural cropland ranges from about 35 percent in Crab Creek drainage basin to a maximum of 75 percent in Lind Coulee drainage basin. More than 95 percent of cropland in Red Rock Coulee, Crab Creek, and Sand Hollow drainage basins is irrigated, whereas only 30 percent of cropland in Lind Coulee is irrigated.

Forty-two pesticides and five metabolites were detected in samples from the four irrigation return-flow drainage basins. The most compounds detected were in samples from Sand Hollow with 37, followed by Lind Coulee with 33, Red Rock Coulee with 30, and Crab Creek with 28. Herbicides were the most frequently detected pesticides, followed by insecticides, metabolites, and fungicides. Atrazine, bentazon, diuron, and 2,4-D were the most frequently detected herbicides and chlorpyrifos and azinphos-methyl were the most frequently detected insecticides.

A statistical comparison of pesticide concentrations in surface-water samples collected in the mid-1990s at Crab Creek and Sand Hollow with those collected in this study showed a statistically significant increase in concentrations for diuron and a statistically significant decrease for ethoprophos and atrazine in Crab Creek. Statistically significant increases were in concentrations of bromacil, diuron, and pendimethalin at Sand Hollow and statistically significant decreases were in concentrations of 2,6-diethylanaline, alachlor, atrazine, DCPA, and EPTC. A seasonal Kendall trend test on data from Lind Coulee indicated no statistically significant trends for any pesticide for 1994 through 2004.

A comparison of pesticide concentrations detected in this study with those detected in previous U.S. Geological Survey National Water-Quality Assessment studies of the Central Columbia Plateau, Yakima River basin, and national agricultural studies indicated that concentrations in this study generally were in the middle to lower end of the concentration spectrum for the most frequently detected herbicides and insecticides, but that the overall rate of detection was near the high end.

Thirty-one of the 42 herbicides, insecticides, and fungicides detected in surface-water samples were applied to the major agricultural crops in the drainage basins, and 11 of the detected pesticides are sold for residential application. Eight of the pesticides detected in surface-water samples were not reported as having any agricultural or residential use. The overall pattern of pesticide use depends on which crops are grown in each drainage basin. Drainage basins with predominantly more orchards have higher amounts of insecticides applied, whereas basins with larger percentages of field crops tend to have more herbicides applied. Pesticide usage was most similar in Crab Creek and Sand Hollow, where the largest total amounts applied were the insecticides azinphos-methyl, carbaryl, and chlorpyrifos and the herbicide EPTC. In Red Rock Coulee basin, DCPA was the most heavily applied herbicide, followed by the fungicide chlorothalonil, the herbicide EPTC, and the insecticides chlorpyrifos and azinphos-methyl. In Lind Coulee, which has a large percentage of dryland agricultural area, the herbicides 2,4-D and EPTC were applied in the largest amount, followed by the fungicide chlorothalonil. The total amount of pesticides applied by residential homeowners and irrigation districts was negligible compared to total amounts applied to agricultural crops. 
The State of Washington criterion of measuring water temperature by the 7-day average of the daily maximum temperatures was beyond the scope of this study, so water temperatures are only an indication of instantaneous temperatures at the time of sampling. Water temperature in 18 samples was greater than the State criterion of 16 degrees Celsius for salmon and trout spawning, core rearing, and migration: 7 in Red Rock Coulee, 5 in Crab Creek, 4 in Lind Coulee, and 2 in Sand Hollow. In 11 of these 18 samples, water temperature also was greater than the criterion of 17.5 degrees Celsius for salmon and trout spawning, non-core rearing, and migration. The State of Washington aquatic-life dissolved-oxygen criterion of 9.5 milligrams per liter for salmon and trout spawning, core rearing, and migration was exceeded eight times from June to early October: two times at Sand Hollow, three times at Red Rock Coulee, and three times at Crab Creek. The State of Washington aquatic-life $\mathrm{pH}$ criterion of 8.5 for fresh water was exceeded 12 times, 6 at Red Rock Coulee, 3 at Sand Hollow, 2 at Lind Coulee and 1 at Crab Creek. Concentrations of nitrate plus nitrite in two samples collected from Sand Hollow during the non-irrigation season exceeded the U.S. Environmental Protection Agency Maximum Contaminant Level for drinking water.

Concentrations of three insecticides and one herbicide exceeded U.S. Environmental Protection Agency or Canadian benchmark for the protection of freshwater aquatic life. Concentrations of the insecticide azinphos-methyl exceeded the aquatic-life benchmark at least once at each of the four sites. Concentrations in samples from Sand Hollow also exceeded the aquatic-life benchmark for chlorpyrifos, lindane, and dinoseb $(0.041,0.01$, and 0.05 micrograms per liter, respectively). Water-quality benchmarks generally were exceeded in June and July, during the middle of the irrigation season, except the benchmark for dinoseb, which was exceeded in one sample during the non-irrigation season in February 2003.

\section{Introduction}

The National Marine Fisheries Service's (NMFS) 2000 Biological Opinion on the operation of the Federal Columbia River Power System (National Marine Fisheries Service, 2000) includes a recommendation to the Bureau of Reclamation to monitor water-quality characteristics of surface-water irrigation return flows to the Columbia River at various points in the Columbia Basin Project (CBP) in central Washington State. The presence of selected pesticides in these return flows at levels that may harm or adversely affect salmon and steelhead species listed for protection under the Endangered Species Act was of specific interest to NMFS.
In cooperation with the Bureau of Reclamation, the U.S. Geological Survey (USGS) included the sampling of surface water in four irrigation return-flow drainage basins in the CBP as an ancillary project to the second phase of the Central Columbia Plateau-Yakima (CCYK) National Water-Quality Assessment (NAWQA) Program. The NAWQA program uses procedures for sampling and analyzing pesticides and other analytes of interest in surface water that assures high-quality, representative data for many commonly used pesticides, and using these same methods for additional CBP sites is beneficial to assure data comparability.

Water-quality samples collected from streamflowgaging station sites in the Crab Creek, Sand Hollow, Red Rock Coulee, and Lind Coulee drainage basins from July 2002 through October 2004 were analyzed for a suite of 107 pesticides and pesticide metabolites (pesticide transformation products), as well as concentrations of major ions, trace elements, and nutrients. The data were used to describe the occurrence, distribution, and transport of pesticides in agricultural irrigation return-flow water in the four irrigationreturn flow drainage basins. Pesticide concentrations were compared with drinking-water standards and aquatic-life benchmarks, and pesticide detections in samples from the irrigation-return flows was compared with historical data and related to current pesticide use, land use, and other environmental factors.

\section{Purpose and Scope}

The purposes of this report are to (1) describe the occurrence, distribution, and transport of pesticides and pesticide metabolites in agricultural irrigation return-flow water in four drainage basins in the CBP; (2) describe the relation between pesticides detected in irrigation-return flows and current and historical pesticide use, land use, other environmental factors, and chemical properties of the pesticides; (3) discuss how measured pesticide concentrations compare with drinking-water standards and aquatic-life benchmarks; and (4) compare the results of this study with those from historical studies in the 1970s, 1990s, and the national NAWQA database. Four irrigation-return flow sites were sampled for pesticides 12 times from July 2002 through October 2004. Ten samples were collected throughout the irrigation season (generally April through October) and two samples were collected during the non-irrigation season.

\section{Environmental Setting}

The CBP is a multi-purpose project providing irrigation water to agricultural land in the Columbia River basin in central Washington (fig. 1). The CBP drainage area is more than $4,000 \mathrm{mi}^{2}$ and is bounded on the west by the Columbia River and on the south by the Snake River, and it extends east and north to include all lands considered 


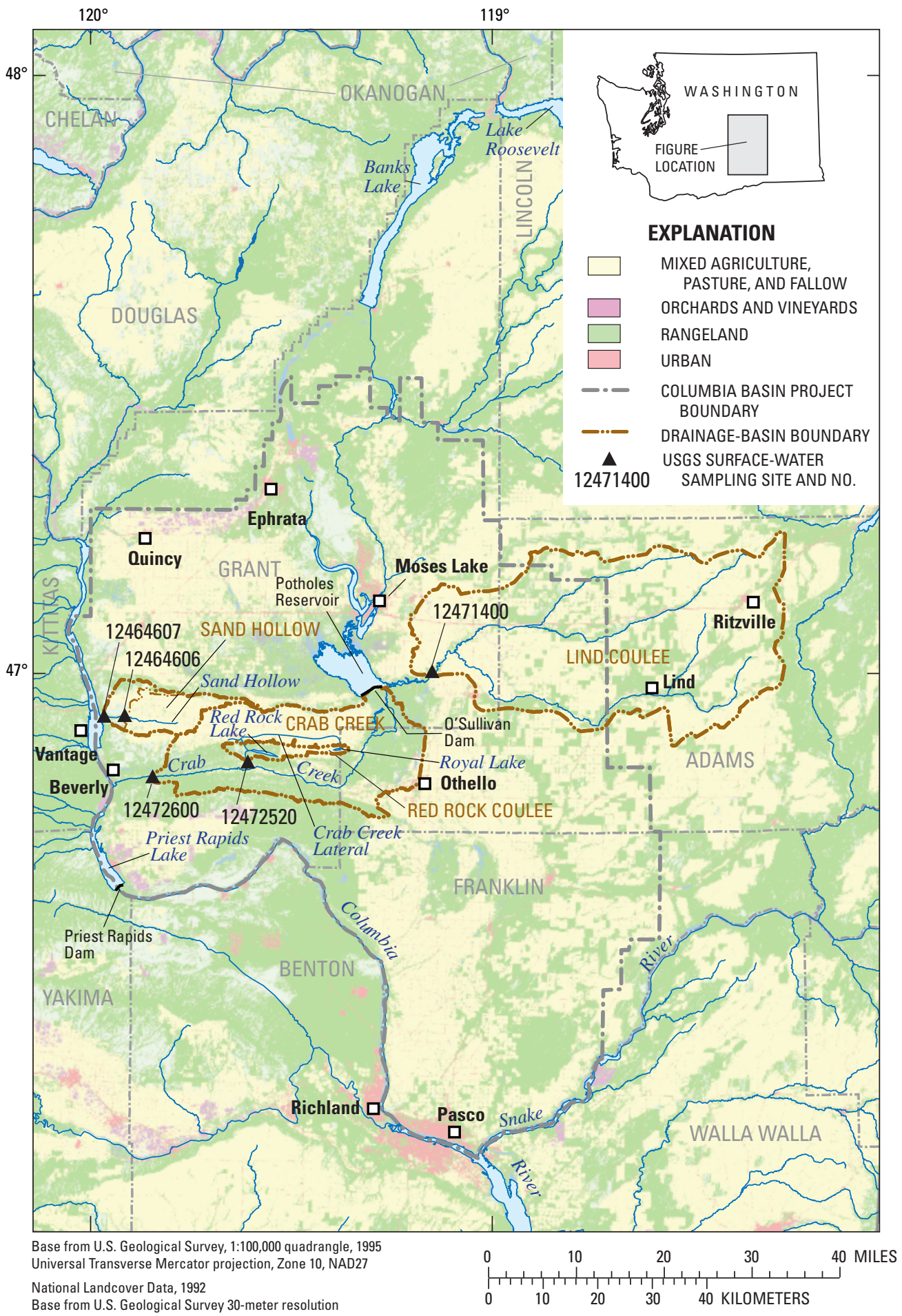

列

Figure 1. Locations of the four irrigation return-flow drainage basins and surface-water sampling sites, Columbia Basin Project, Washington.

economically irrigable from the project canal system (Bureau of Reclamation, 1982). Main geohydrologic units in the CBP are the Columbia Plateau River Basalt Group, extrusions of basalt lava that formed the Columbia Plateau between 6 and 16.5 million years ago, and the overlying deposits of unconsolidated sediment (Drost and others, 1990). Columbia Plateau River Basalt Group flows are estimated to be more than 14,000 ft thick near Pasco, Washington. Parts of the CBP also contain loess, a wind-deposited silt, and sand dunes typified by those at Potholes Reservoir. 
Major land use and economy in the CBP is agriculture, followed by livestock production and food processing. The land is primarily rural, but five towns in the CBP area have populations greater than 5,000: Pasco, Othello, Moses Lake, Ephrata, and Quincy. Pasco is the largest town, with a population of about 32,000 (U.S. Census Bureau, 2004). Climate in the CBP is semiarid, with about 6 to $10 \mathrm{in}$. of annual precipitation, and air temperatures range from below freezing in winter to more than $38^{\circ} \mathrm{C}$ at times during summer.

The CBP has few natural perennial streams, and streamflow in the project area is augmented and indirectly regulated by seasonal delivery of irrigation water (generally April to October) to the area. Irrigation water is pumped from Lake Roosevelt, stored in Banks Lake, and distributed throughout the CBP by a network of re-regulation reservoirs and conveyance canals to irrigated lands. Surface-water drainages from irrigated lands lead to wasteway returns that create irrigation-return flows to major streams and rivers. The large quantities of irrigation water delivered to farm units in the CBP indirectly control the irrigation-return flow in the four drainage basins studied in the project area during the irrigation season (table 1). Water samples were collected at USGS streamflow-gaging stations in the study basins, and continuous streamflow data were available only for Crab Creek and Lind Coulee.

Crab Creek irrigation-return drainage basin covers $296 \mathrm{mi}^{2}$, and water samples were collected at gaging station 12472600, near Beverly (fig. 1). Before water was diverted from Lake Roosevelt for irrigation, Crab Creek was one of the few perennial streams in the CBP and flowed from the northeastern Columbia Plateau, about 3 mi east of Reardan, southwest to where it empties into the Columbia River near Beverly, Washington. Drifting sand dunes impounded Crab Creek and created Moses Lake, the largest natural lake in the
CBP (Walters and Grolier, 1960). Construction of O'Sullivan Dam formed Potholes Reservoir, creating a central point in the CBP for storage of excess canal water, natural runoff, and irrigation-return flow and redistribution of water for irrigation reuse in the southern part of the CBP. The entire length of Crab Creek drains 4,840 $\mathrm{mi}^{2}$, but Moses Lake and Potholes Reservoir hydrologically separate the stream into Upper Crab Creek, the stretch from the headwaters to Moses Lake, and Lower Crab Creek, the stretch from O'Sullivan Dam to the mouth that includes the Crab Creek study basin. Potholes Reservoir has no perennial outlet to Lower Crab Creek, and most water in Lower Crab Creek comes from Goose Lake Wasteway. Hansen and others (1994) calculated average ground-water discharge to Lower Crab Creek as $76.3 \mathrm{ft}^{3} / \mathrm{s}$ prior to irrigation development and $145.1 \mathrm{ft}^{3} / \mathrm{s}$ for $1983-85$. Therefore, water at the Crab Creek site near Beverly is directly affected by ground-water seepage from Potholes Reservoir and from tributary inflow downstream of O'Sullivan Dam.

Sand Hollow drains the western flanks of Royal Slope and flows west, emptying into the Columbia River across from Vantage, Washington. Sand Hollow irrigation-return drainage basin covers $60 \mathrm{mi}^{2}$ and represents a drainage basin of varied agricultural land uses that is irrigated primarily by surface water. The first water sample from Sand Hollow during this study was collected at S Road SW at gaging station 12464606 (fig. 1). Historical data were collected at this site by NAWQA during the 1990s. The drainage area at this site is $43 \mathrm{mi}^{2}$. All subsequent samples for this study were collected at the mouth at gaging station 12464607 (fig. 1), where one water sample was collected by the USGS in 1991 and sediment samples were collected in 1992. Although a minor tributary flows into Sand Hollow in the 3 mi between S Road SW and the mouth, land use is the same for the entire basin and data from both sampling sites are treated as one for data analysis in this study.

Table 1. Physical and land-use characteristics of the four irrigation return-flow drainage basins sampled for pesticides, Columbia Basin Project, Washington, July 2002 to October 2004.

[USGS, U.S. Geological Survey; $\mathrm{ft}^{3} / \mathrm{s}$, cubic feet per second; $\mathrm{mi}^{2}$, square mile; S, south; Rd, Road; SW, Southwest; SR, State Route; >, greater than]

\begin{tabular}{|c|c|c|c|c|c|c|c|c|c|c|c|}
\hline \multirow{2}{*}{$\begin{array}{l}\text { Irrigation } \\
\text { return-flow } \\
\text { basin }\end{array}$} & \multicolumn{2}{|r|}{ Sampling site } & \multirow{2}{*}{$\begin{array}{l}\text { Short } \\
\text { name }\end{array}$} & \multirow{2}{*}{$\begin{array}{c}\text { Number of } \\
\text { samples }\end{array}$} & \multicolumn{3}{|c|}{$\begin{array}{l}\text { Streamflow at time of } \\
\text { sampling }\left(\mathrm{ft}^{3} / \mathrm{s}\right)\end{array}$} & \multirow{2}{*}{$\begin{array}{c}\text { Drainage } \\
\text { area } \\
\left(\mathrm{mi}^{2}\right)\end{array}$} & \multirow{2}{*}{$\begin{array}{c}\text { Harvested } \\
\text { cropland } \\
\text { area } \\
\left(\mathrm{mi}^{2}\right)\end{array}$} & \multirow{2}{*}{$\begin{array}{l}\text { Percentage } \\
\text { of harvested } \\
\text { cropland }\end{array}$} & \multirow{2}{*}{$\begin{array}{c}\text { Percentage } \\
\text { of irrigated } \\
\text { cropland }\end{array}$} \\
\hline & \multicolumn{2}{|c|}{ USGS gaging station No. and name } & & & Median & Minimum & Maximum & & & & \\
\hline Crab Creek & 12472600 & Crab Creek near Beverly & Crab Creek & 12 & 214 & 129 & 331 & 1296 & 103 & 35 & $>95$ \\
\hline Lind Coulee & 12471400 & $\begin{array}{l}\text { Lind Coulee Wasteway at } \\
\text { SR } 17 \text {, near Warden }\end{array}$ & Lind Coulee & 12 & 255 & 58 & 355 & 710 & 533 & 75 & 30 \\
\hline \multirow[t]{2}{*}{ Sand Hollow } & 12464606 & $\begin{array}{l}\text { Sand Hollow at S Rd SW, } \\
\text { near Vantage }\end{array}$ & $\begin{array}{l}\text { Sand Hollow } \\
\text { at S Rd }\end{array}$ & 1 & 79 & 79 & 79 & 43 & 36 & 70 & $>95$ \\
\hline & 12464607 & $\begin{array}{l}\text { Sand Hollow at mouth, } \\
\text { near Vantage }\end{array}$ & Sand Hollow & 11 & 94 & 23 & 141 & 60 & 42 & 84 & $>95$ \\
\hline
\end{tabular}

${ }^{1}$ Drainage area is for Lower Crab Creek; the entire Crab Creek drainage area is $4,840 \mathrm{mi}^{2}$. 
Red Rock Coulee drains about $19 \mathrm{mi}^{2}$ of irrigated agricultural land, beginning near the eastern boundary of Grant County, just north of Royal Lake, and flowing west to Red Rock Lake (fig. 1). Red Rock Coulee flows out of Red Rock Lake, passes through a culvert beneath county road E SW, flows south about $2.5 \mathrm{mi}$ before crossing beneath county road E SW again, and continues another mile before emptying into Crab Creek. During this study, samples were collected from Red Rock Coulee downstream of the second culvert at gaging station 12472520, but during the NAWQA program, in 1994, one sample was collected about 1 mi upstream.

The headwaters of Lind Coulee combine with the flow of several smaller coulees south of Ritzville, and the main branch flows east through the town of Lind before joining with Weber Coulee and flowing another $5 \mathrm{mi}$ to empty into Potholes Reservoir. Weber Coulee combines the flow from Bauer Coulee and Farrier Coulee, and the entire Lind Coulee basin drains about $710 \mathrm{mi}^{2}$. Samples from Lind Coulee were collected at gaging station 12471400 , about 1 mi downstream of the State Highway 17 crossing.

Agriculture crop acreage in the four irrigation-return flow drainage basins varies from year to year. Orchards usually are a long-term crop, but many field crops are rotated frequently. One primary rotation in the CBP is between alfalfa, corn, and potatoes. Estimates of agricultural acreage for 2003 in the four irrigation-return flow basins were used to describe the agricultural land use during this study (table 2; Patricia Daly, Franklin County Conservation District, written commun., 2004). Percentage of agricultural harvested cropland varies from year to year, but ranged from 35 percent in Crab Creek basin to a maximum of 75 percent in Lind Coulee basin during this study. Harvested cropland was 47 percent in Red Rock Coulee basin and 70 percent in Sand Hollow basin during the current study. Most agricultural cropland in Red Rock Coulee, Sand Hollow, and Crab Creek drainage basins is irrigated, but only 30 percent of the crop acreage in Lind Coulee is irrigated (table 1). Alfalfa is the largest percentage of crop acreage in Crab Creek drainage basin, followed by orchards and irrigated wheat. Peas, corn, and potatoes are nearly 20 percent of crop acreage in the Crab Creek drainage basin (table 2). Nearly one-third of the crop acreage in Lind Coulee is in dryland wheat, and more than one-third of the acreage is fallow land. Minor percentages of the acreage in Lind Coulee drainage basin are in alfalfa, potatoes, and peas. The largest percentage of crop acreage in Red Rock Coulee drainage basin is alfalfa, followed by onions and orchards. Peas and irrigated wheat make up about 15 percent of the total agricultural acreage. The largest percentage of crop acreage in Sand Hollow also is alfalfa, followed by orchards. Peas and irrigated wheat make up about 30 percent of the total agricultural acreage, followed by minor percentages of grass, potatoes, and mint.
Table 2. Crop acreage estimates in the four irrigation return-flow drainage basins, Columbia Basin Project, Washington, 2003.

[Data for crop-acreage estimates provided by Franklin County Conservation District (Patricia Daly, written commun., 2004). Percentage of crop acreage: may not add to 100 percent due to rounding. <, less than]

\begin{tabular}{|c|c|c|}
\hline Crop & Acres & $\begin{array}{l}\text { Percentage of } \\
\text { crop acreage }\end{array}$ \\
\hline \multicolumn{3}{|c|}{ Crab Creek } \\
\hline Alfalfa & 24,292 & 37 \\
\hline Orchard & 13,999 & 21 \\
\hline Wheat (irrigated) & 6,662 & 10 \\
\hline Pea & 5,172 & 8 \\
\hline Corn & 3,666 & 6 \\
\hline Potato & 3,600 & 5 \\
\hline Unclassified & 2,598 & 4 \\
\hline Grass & 1,814 & 3 \\
\hline Onion & 1,603 & 2 \\
\hline Wheat (dryland) & 1,189 & 2 \\
\hline Mint & 983 & 1 \\
\hline Timothy & 162 & $<1$ \\
\hline Fallow & 98 & $<1$ \\
\hline \multicolumn{3}{|c|}{ Lind Coulee } \\
\hline Fallow & 119,929 & 35 \\
\hline Wheat (dryland) & 116,713 & 34 \\
\hline Wheat (irrigated) & 33,835 & 10 \\
\hline Alfalfa & 17,899 & 5 \\
\hline Potato & 15,238 & 4 \\
\hline Unclassified & 13,646 & 4 \\
\hline Corn & 9,667 & 3 \\
\hline Pea & 8,074 & 2 \\
\hline Orchard & 4,206 & 1 \\
\hline Onion & 1,183 & $<1$ \\
\hline Grass & 686 & $<1$ \\
\hline \multicolumn{3}{|c|}{ Red Rock Coulee } \\
\hline Alfalfa & 3,345 & 57 \\
\hline Onion & 682 & 12 \\
\hline Orchard & 536 & 9 \\
\hline Wheat (irrigated) & 449 & 8 \\
\hline Pea & 428 & 7 \\
\hline Potato & 129 & 2 \\
\hline Corn & 122 & 2 \\
\hline Unclassified & 116 & 2 \\
\hline Grass & 105 & 2 \\
\hline \multicolumn{3}{|c|}{ Sand Hollow } \\
\hline Alfalfa & 7,610 & 28 \\
\hline Orchard & 4,746 & 18 \\
\hline Pea & 4,091 & 15 \\
\hline Wheat (irrigated) & 4,001 & 15 \\
\hline Grass & 2,378 & 9 \\
\hline Potato & 1,216 & 5 \\
\hline Mint & 1,070 & 4 \\
\hline Corn & 602 & 2 \\
\hline Unclassified & 601 & 2 \\
\hline Fallow & 181 & 1 \\
\hline Wheat (dryland) & 164 & 1 \\
\hline Onion & 125 & $<1$ \\
\hline
\end{tabular}




\section{Acknowledgments}

The authors are grateful for the technical reviews by Frank Rinella (USGS, Portland, Oreg.), Angela Crain (USGS, Louisville, Ky.), and Bryan Horsburgh (Bureau of Reclamation, Boise, Idaho). We are grateful for the technical advice on aquatic toxicity from Patrick Moran (USGS, Tacoma, Wash.), Lisa Nowell (USGS, Sacramento, Calif.), and Mark Schneider (National Oceanographic and Atmospheric Administration Fisheries, Portland, Oreg.); for the agricultural crop acreages data provided by Patricia Daly (Franklin County Conservation District); and to Gina Hoff (Bureau of Reclamation, Ephrata, Wash.), Elizabeth Jordan (Quincy Basin Irrigation District, Quincy, Wash.), and Elaine Fuller (East Columbia Basin Irrigation District, Othello, Wash.), for non-agricultural aquatic herbicide application data. The contribution by Theresa Olsen (USGS, Tacoma, Wash.) to GIS illustrations and to analysis of crop pesticide-application data was invaluable. We are grateful to Dwight Copeland and Douglas Call (USGS, Pasco, Wash.), Brett Smith and Galen Schuster (USGS, Spokane, Wash.), and Richard Cornet (Bureau of Reclamation, Ephrata, Wash.) for their assistance in collecting samples for this study.

\section{Methods}

Surface-water samples were collected from four irrigation return-flow drainage basins and analyzed for pesticides and pesticide metabolites, major ions, trace elements, and nutrients (table 3). The pesticides were selected by the NAWQA program (Gilliom and others, 1995) from a list of about 400 pesticides most commonly used in the United States (Gianessi and Puffer, 1991, 1992a, 1992b). Each pesticide was selected on the basis of the following factors: a national use of more than 8,000 lb of active ingredient annually; inclusion in the analytical schedules of other Federal monitoring or survey programs; toxicity; leachability; and its ability to be trapped and extracted from the appropriate solid-phase-concentrating matrix. Samples for analysis of pesticides and major ions were collected and submitted to the USGS National Water Quality Laboratory (NWQL) in Lakewood, Colo., the samples for pesticides were analyzed using either gas-chromatography/ mass spectrometry (GC/MS) or high-performance liquid chromatography/mass spectrometry (HPLC/MS), depending on the physical characteristics of the target analytes. Samples for nutrient analysis were sent to the Bureau of Reclamation laboratory in Boise, Idaho.

\section{Field Methods}

The sampling site in each drainage basin was visited 10 times during the irritation season and 2 times during the non-irrigation season from July 2002 to October 2004. During each visit, water temperature, $\mathrm{pH}$, dissolved oxygen (DO) concentrations, and specific conductance were measured and water samples were collected for analysis of pesticides, major ions, trace elements, and nutrients. The first sample from Sand Hollow drainage basin was collected from the bridge at S Road SW and all subsequent samples were collected from the mouth of Sand Hollow before it empties into the Columbia River. One DO measurement was removed from the data set because of a faulty sensor. Samples representative of flow in the stream cross section were obtained by collecting depthintegrated subsamples at equally spaced verticals across the stream using a US DH-81 sampler as described by Edwards and Glysson (1999) and Wilde and others (1999a). The sampler holds a 1- or 3-L Teflon ${ }^{\circledR}$ bottle, and all parts of the sampler coming in contact with the water sample are made of Teflon®. Subsamples were composited and split using a Teflon ${ }^{\circledR}$ churn splitter (Wilde and others, 2004). From June through August 2002, the Teflon ${ }^{\circledR}$ churn was not available, so a polyethylene churn splitter was used. Subsamples for analysis of inorganic analytes were collected and split out using the churn. Samples for pesticides were collected directly into a 3-L Teflon $®$ bottle from each section of the stream and were not composited into the polyethylene churn. Water samples for pesticides were drawn from the Teflon $₫$ churn splitter (after August 2002) and filtered through a $0.7-\mu \mathrm{m}$ baked glass-fiber filter into 1-L baked glass bottles, stored at less than $4^{\circ} \mathrm{C}$, and shipped to the NWQL within 24 hours. Samples for major ions and nutrients were drawn from the churn splitter and filtered or preserved, if necessary. Subsamples for analysis of filtered nutrients were pumped through a disposable $0.45-\mu \mathrm{m}$ filter cartridge into opaque polyethylene bottles and chilled to less than $4^{\circ} \mathrm{C}$. Samples for analysis of unfiltered nutrients were collected in translucent polyethylene bottles and preserved with sulfuric acid to a $\mathrm{pH}$ less than 2. Samples for analysis of major ions also were filtered through a $0.45-\mu \mathrm{m}$ filter cartridge, and samples for analysis of cations, iron, and manganese were acidified with nitric acid to a $\mathrm{pH}$ less than 2. Samples were shipped on ice to the NWQL for pesticide and major ions analysis, and samples were shipped to the Bureau of Reclamation Boise laboratory for nutrients analysis. All equipment used to collect and process samples was cleaned with a 0.2-percent non-phosphate detergent, soaked in a 5-percent hydrochloric acid solution, and rinsed with deionized water, as described in Wilde (2004). Equipment used to filter the pesticide samples was additionally rinsed with pesticide-grade methanol and pesticide-free reagent water. All cleaned equipment was placed in doubled plastic bags and stored in a dust-free environment prior to sample collection. 
Table 3. Inorganic and organic analytes and schedules, analytical methods, and references.

[Abbreviations: ${ }^{\circ} \mathrm{C}$, degrees Celsius; CAS, Chemical Abstract Services; IC, ion-chromatography; ASF, automated-segment flow; ISE, ion-selective electrode; ICP, inductively coupled plasma; SPE, solid-phase extraction; GC/MS, gas-chromatography/mass spectrometry; HPLC/MS, high-performance liquid chromatography/mass spectrometry; USEPA, U.S. Environmental Protection Agency]

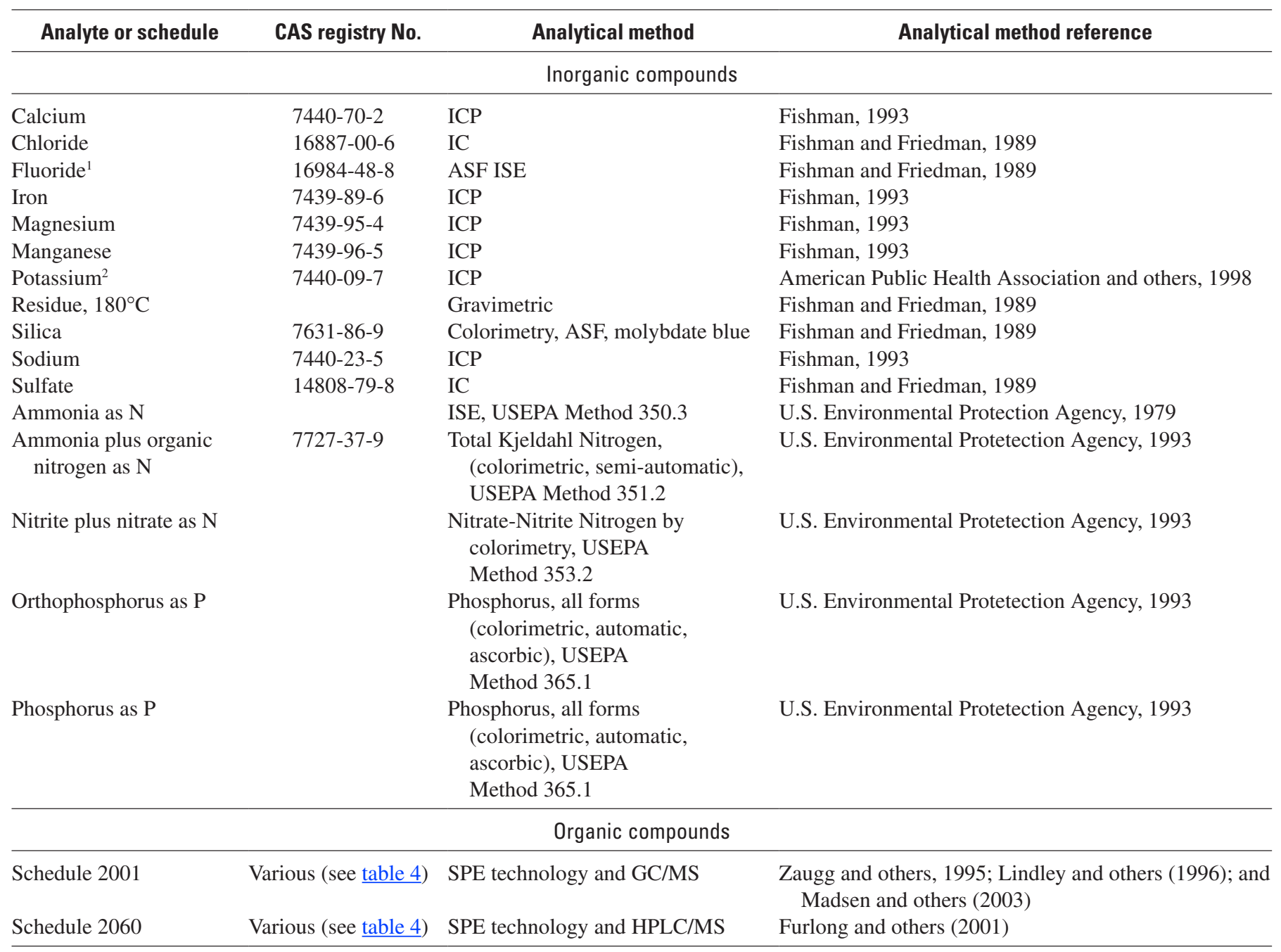

${ }^{1}$ Analyzed by manual ISE method (Fishman and Friedman, 1989) from July 2002 through April 2003.

${ }^{2}$ Analyzed by flame atomic absorption (Faires, 1993) prior to May 2003.

\section{Laboratory Methods}

Samples for a broad spectrum of pesticides were analyzed at the NWQL using either gas chromatography/ mass spectrometry (GC/MS) or high-performance liquid chromatography/mass spectrometry (HPLC/MS) techniques (table 4). Compounds that were sufficiently volatile and thermally stable for gas chromatography were analyzed by GC/MS, as described by Zaugg and others (1995), Lindley and others (1996), and Madsen and others (2003); the remaining pesticides were analyzed by HPLC/MS, as described by Furlong and others (2001).
The USGS NWQL collects water-quality control data on a continuing basis for method evaluation and to determine long-term method detection levels (LT-MDLs) and laboratory reporting levels (LRLs). Concentrations are reported as less than the LRL for samples in which the analyte was not detected or failed to meet necessary identification criteria. Analytes detected at concentrations lower than the lowest calibration standard or between the LT-MDL and the LRL and that pass identification criteria are reported with a remark code of "E". In addition, some analytes generally have low or variable recovery and routinely are reported with an "E" remark code. 
Table 4. Pesticide target analytes, laboratory reporting levels, drinking water standards or guidelines, and aquatic-life benchmarks.

[If laboratory reporting level changed during the study, the most frequently used level is indicated. Pesticide target analyte: CIAT, 2-chloro-4-isopropylamino6-amino-s-triazine; CAAT, chlorodiamino-s-triazine; OIET, 2-hydroxy-4-isopropylamino-6-ethylamino-s-triazine; CEAT, 2-chloro-6-ethylamino-4-amino$s$-triazine; GC/MS, gas chromatography/mass spectrometry; HPLC/MS, high-performance liquid chromatography/mass spectrometry. Type of pesticide: F, fungicide; H, herbicide; I, insecticide; S, stimulant; T, transformation product. Drinking-water standards and guidelines: Maximum contaminant levels for drinking water from U.S. Environmental Protection Agency (2004a). Freshwater aquatic-life benchmark: From U.S. Environmental Protection Agency (2004b), unless otherwise footnoted. Abbreviations: CAS, Chemical Abstracts Service; $\mu \mathrm{g} / \mathrm{L}$, microgram per liter; -, no data or not available; *, interim values (Canadian Council of Resource and Environment Ministers, 1997)]

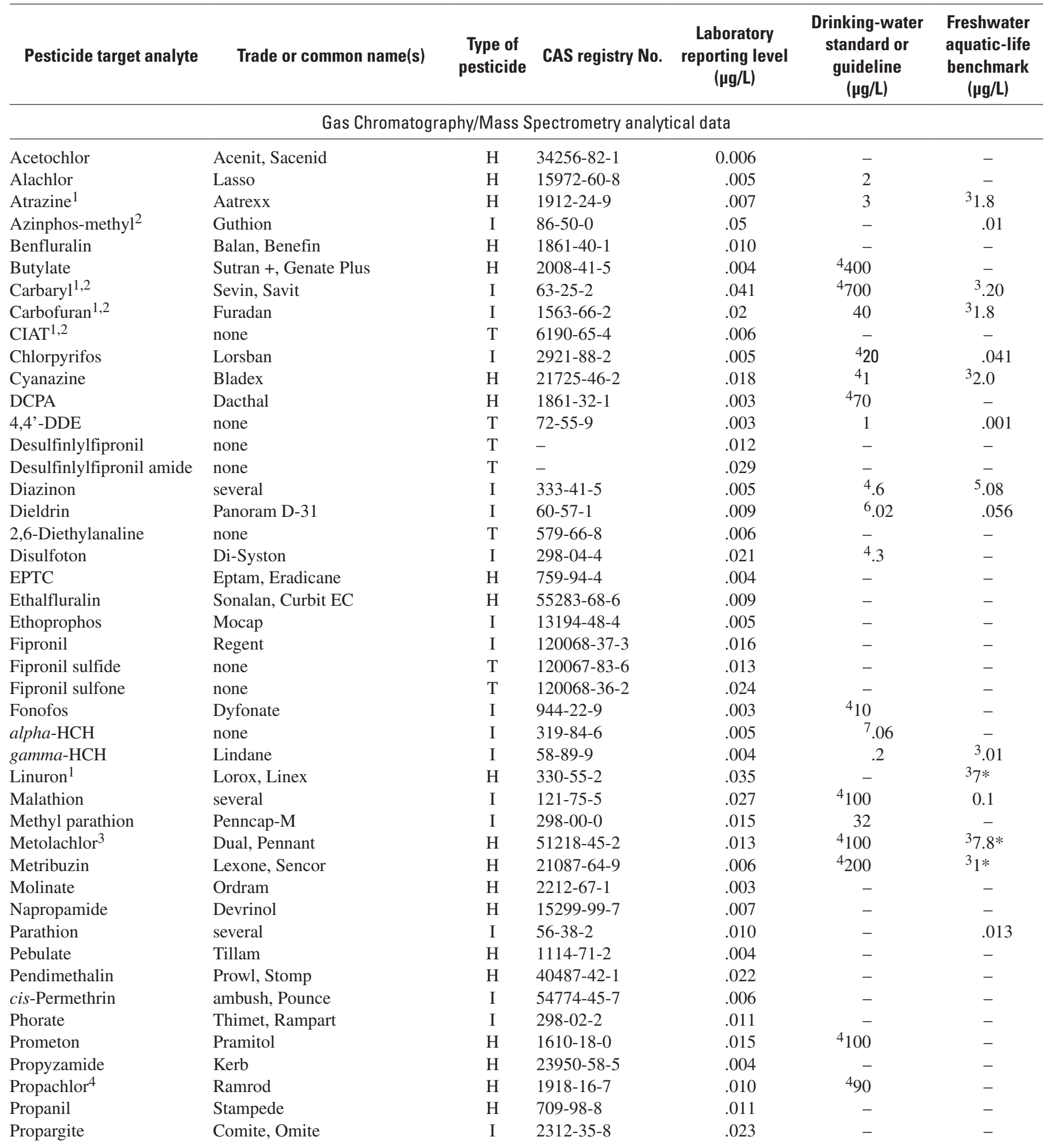


Table 4. Pesticide target analytes, laboratory reporting levels, drinking water standards or guidelines, and aquatic-life benchmarks—Continued

[If laboratory reporting level changed during the study, the most frequently used level is indicated. Pesticide target analyte: CIAT, 2-chloro-4-isopropylamino6-amino-s-triazine; CAAT, chlorodiamino-s-triazine; OIET, 2-hydroxy-4-isopropylamino-6-ethylamino-s-triazine; CEAT, 2-chloro-6-ethylamino-4-amino$s$-triazine; GC/MS, gas chromatography/mass spectrometry; HPLC/MS, high-performance liquid chromatography/mass spectrometry. Type of pesticide: F, fungicide; H, herbicide; I, insecticide; S, stimulant; T, transformation product. Drinking-water standards and guidelines: Maximum contaminant levels for drinking water from U.S. Environmental Protection Agency (2004a). Freshwater aquatic-life benchmark: From U.S. Environmental Protection Agency (2004b), unless otherwise footnoted. Abbreviations: CAS, Chemical Abstracts Service; $\mu \mathrm{g} / \mathrm{L}$, microgram per liter; - , no data or not available; *, interim values (Canadian Council of Resource and Environment Ministers, 1997)]

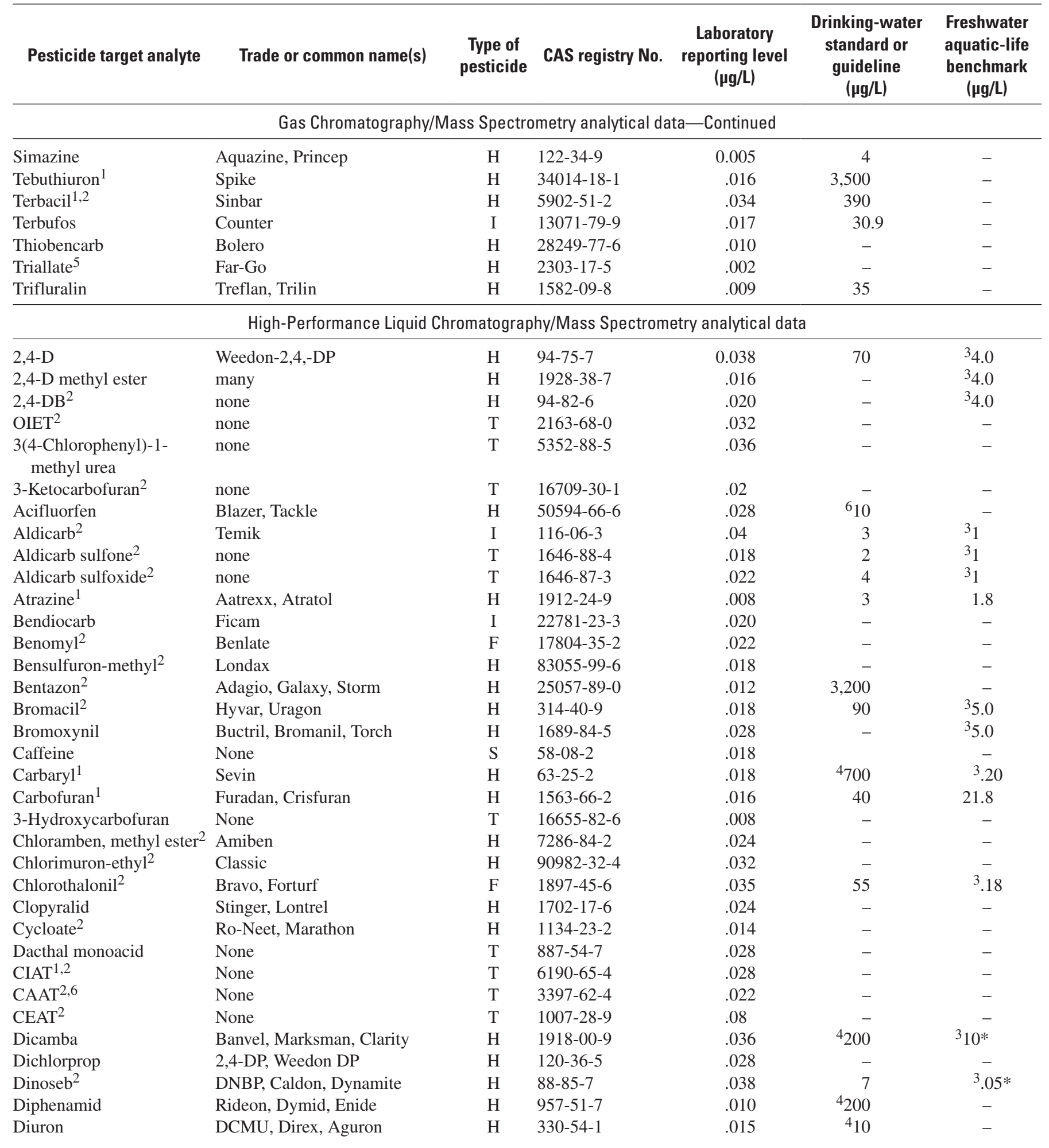


Table 4. Pesticide target analytes, laboratory reporting levels, drinking water standards or guidelines, and aquatic-life benchmarks—Continued

[If laboratory reporting level changed during the study, the most frequently used level is indicated. Pesticide target analyte: CIAT, 2-chloro-4-isopropylamino6-amino-s-triazine; CAAT, chlorodiamino-s-triazine; OIET, 2-hydroxy-4-isopropylamino-6-ethylamino-s-triazine; CEAT, 2-chloro-6-ethylamino-4-amino$s$-triazine; GC/MS, gas chromatography/mass spectrometry; HPLC/MS, high-performance liquid chromatography/mass spectrometry. Type of pesticide: F, fungicide; H, herbicide; I, insecticide; S, stimulant; T, transformation product. Drinking-water standards and guidelines: Maximum contaminant levels for drinking water from U.S. Environmental Protection Agency (2004a). Freshwater aquatic-life benchmark: From U.S. Environmental Protection Agency (2004b), unless otherwise footnoted. Abbreviations: CAS, Chemical Abstracts Service; $\mu \mathrm{g} / \mathrm{L}$, microgram per liter; - , no data or not available; *, interim values (Canadian Council of Resource and Environment Ministers, 1997)]

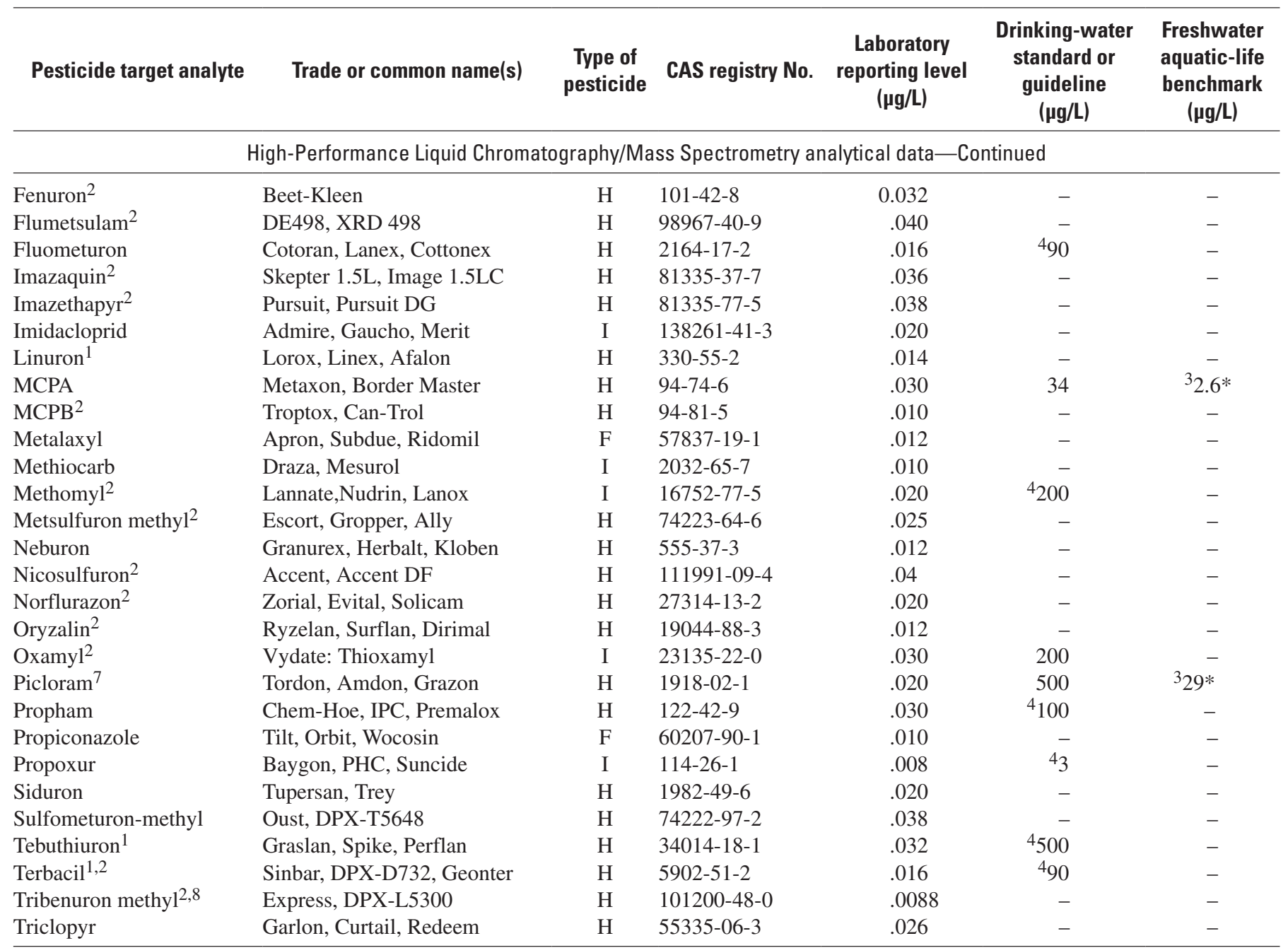

\footnotetext{
${ }^{1}$ Analyzed by GC/MS and HPLC/MS.

${ }^{2}$ Because recovery or variation in recovery was outside the acceptable range, compound is qualified with an E-code (estimated).

${ }^{3}$ Canadian water-quality guidelines for the protection of freshwater aquatic life (Canadian Council of Ministers of the Environment, 2003).

${ }^{4}$ U.S. Environmental Protection Agency lifetime-health advisory for a 70-kilogram adult (U.S. Environmental Protection Agency, 2004a).

${ }^{5}$ Great Lakes water-quality objective for protection of aquatic life, from the International Joint Commission (IJC) Canada and United States, 1978.

${ }^{6}$ U.S. Environmental Protection Agency risk-specific dose health advisory associated with a cancer risk of 10-5 (1 in 100,000) was calculated from riskspecific dose of 10-4 (RSD4) (U.S. Environmental Protection Agency, 2004a).

${ }^{7}$ U.S. Environmental Protection Agency risk-specific dose health advisory associated with a cancer risk of 10-5 (1 in 100,000), from USEPA Integrated Risk Information System (IRIS) data base (U.S. Environmental Protection Agency, 2005b).

${ }^{8}$ Tibenuron methyl was routinely reported by the laboratory as a null result because of problems with stability of calibration standards. The analyte was removed from the analytical method September 30, 2004.
} 


\section{Quality Assurance/Quality Control}

About 15 percent of all samples submitted to the laboratories were quality-control samples, which included field blanks and equipment blanks to measure possible contamination and bias; replicate samples to measure variability; and field-matrix spike samples to measure recovery of analytes. All samples for pesticide analysis were spiked with surrogate analytes prior to extraction, to monitor accuracy and precision of the analytical procedures. Wilde and others (1999b) define these quality-control samples. Additionally, laboratory quality-control samples were routinely analyzed as part of the laboratory quality-assurance plan described by Maloney (2005).

Field- and equipment-blank samples for pesticide analysis were free of contamination, except for detection of EPTC in one field blank at a concentration of $0.043 \mu \mathrm{g} / \mathrm{L}$ and detection of caffeine in one field blank at an estimated concentration of $0.00043 \mu \mathrm{g} / \mathrm{L}$. No adjustments were made in the data set or data analysis on the basis of these results.

Precision data were obtained for two sets of replicate pesticide samples (table 16, at back of report). Differences in concentration between replicates ranged from 0 to 71 percent, as measured by relative percentage of difference ( 94 percent of the differences were $\leq 5$ percent). Percentage of relative differences for atrazine ranged from 5.1 to 71 percent. The relative percentage of difference was 5.1 for one set of replicates using the GS/MS techniques; the relative percentage of difference was 62 and 71 for two other sets of replicates analyzed using the HPLC/MS method. The GC/MS technique is the preferred method of analysis and is the value used for all data analysis. No modifications were made to the data set based on these results. Mean recovery percentages of GC/MS target analytes in field-matrix spike samples ranged from 33 to 213 percent, with a median recovery of 97.5 percent (table 17, at back of report). Mean recovery percentages of HPLC/MS target analytes in field-matrix spike samples ranged from 34 to 150 percent (table 17), with a median recovery of 86.5 percent. Although recoveries of HPLC/MS target analytes generally were lower than recoveries of GC/MS target analytes, recoveries generally are large enough and consistent enough that the data are acceptable and useful for analysis. However, because of lower recoveries and greater variability, the probability of false negatives is greater for HPLC/MS target analytes than for GC/MS and the effective detection level generally is larger. No modifications were made to the environmental data set, but recovery percentages for these analytes need to be considered when interpreting the data.

Seven pesticides were analyzed by GC/MS and HPLC/MS methods. Three pesticides (atrazine, CIAT, and tebuthiuron) were reported only by the "preferred" method (GC/MS). The remaining four pesticides (carbaryl, carbofuran, linuron, and terbacil) were reported with both methods. The NWQL uses a hierarchical procedure in selecting the "preferred" method for these compounds (Mark Sandstrom, USGS National Water Quality Laboratory, written commun., 2004). For the current study, all pesticides were included in the analysis of quality-control samples to determine intralaboratory method precision and accuracy. Precision between analytical methods is summarized in table 18 (at back of report). Generally, precision between the two analytical methods is good. Comparison between the two methods can be summarized into four categories: (1) both methods reported no detections, (2) both methods reported a detection, (3) one method reported no detection and the other method reported a detection that was either near or less than the reporting level of the other method, and (4) one method reported no detection and the other method reported a detection that was larger than the reporting level of the other method. For example, case 3 is illustrated by a detection of CIAT ${ }^{\mathrm{E}} 0.008$ by GC/MS and the HPLC/MS method reporting of CIAT as less than 0.028 . Case 4 only occurred with analysis of terbacil, and an example is the detection by GC/MS of ${ }^{\mathrm{E}} 0.026$ and the HPLC/MS method reporting of less than 0.010. One method reported a detection and the other did not a total of 13 percent of the time, 11 percent of the time as a case 3 difference and 2 percent of the time as a case 4 difference. This likely indicates the preference for the GC/MS method for the analysis of terbacil. 


\section{Occurrence, Distribution, and Transport of Pesticides}

All samples were analyzed for concentrations of pesticides, major ions, iron, manganese, and nutrients. Summaries of results for inorganic constituents and pesticides are presented. Estimates of pesticide use are discussed and compared in relation to detected and non-detected pesticides, and a comparison is made between pesticides detected in this study and pesticides detected in earlier studies.

\section{Field Measurements and Inorganic Constituents}

Water temperature, $\mathrm{pH}, \mathrm{DO}$ concentrations, specific conductance and concentrations of major ions, trace elements, and nutrients data were measured at all sampling sites where pesticide data were collected (table 5). Water-temperature measurements are subject to the water-temperature criteria for core and non-core designated use by fish in the Washington 2003 water-quality standards (State of Washington, 2003). (The term "non-core" to refers to "salmon and trout spawning, non-core rearing, and migration" designated use and "core" refers to the "salmon and trout spawning, core rearing, and migration" designated use.) The criteria specify that water temperature be measured by the 7-day average of daily maximum temperatures (7DADMax; State of Washington, 2003), but extended deployment of temperature sensors and calculation of a 7-day average of maximum temperatures were beyond the scope of this study. Water temperatures measured during this study are only an indication of instantaneous temperatures at time of sampling and indicate that the temperature criterion may have been exceeded.

Measured water temperature was greater than the State of Washington criterion of $16^{\circ} \mathrm{C}$ for core rearing, salmon and trout spawning, and migration in 18 instances. These exceedances occurred 7 times at Red Rock Coulee, 5 times at Crab Creek, 4 times at Lind Coulee, and 2 times at Sand Hollow. In 11 of these 18 instances, measured temperature also was greater than the criterion of $17.5^{\circ} \mathrm{C}$ for non-core rearing, salmon and trout spawning, migration, and salmon and trout rearing and migration only.

The State of Washington aquatic-life criteria for DO are listed as 1-day minimum. The criterion of $9.5 \mathrm{mg} / \mathrm{L}$ for salmon and trout spawning, core rearing, and migration was exceeded eight times at three sites during this study from June to early October: two times at Sand Hollow, three times at Red Rock Coulee, and three times at Crab Creek. State of Washington aquatic-life criterion for $\mathrm{pH}$ of 8.5 for fresh water was exceeded 12 times: 6 times at Red Rock Coulee, 3 times at Sand Hollow, 2 times at Lind Coulee, and 1 time at Crab Creek.

Table 5. Summary of field measurements and concentrations of inorganic constituents in surface-water samples collected from the four irrigation return-flow drainage basins, Columbia Basin Project, July 2002 through October 2004.

[Dissolved solids, residue on evaporation, dried at 180 degrees Celsius. Abbreviations: $\mathrm{ft}^{3} / \mathrm{s}$, cubic foot per second; ${ }^{\circ} \mathrm{C}$; degrees Celsius; $\mu \mathrm{S} / \mathrm{cm}$, microsiemens per centimeter; $\mathrm{mg} / \mathrm{L}$, milligram per liter; $\mathrm{CaCO}_{3}$, calcium carbonate; $\mu \mathrm{g} / \mathrm{L}$, microgram per liter; $\mathrm{E}$, estimated (below laboratory reporting level); <, less than]

\begin{tabular}{|c|c|c|c|c|}
\hline \multirow{2}{*}{ Constituent or property } & \multirow{2}{*}{$\begin{array}{c}\text { Number of } \\
\text { samples }\end{array}$} & \multicolumn{3}{|c|}{ Value } \\
\hline & & Minimum & Maximum & Median \\
\hline \multicolumn{5}{|c|}{ Crab Creek } \\
\hline \multicolumn{5}{|l|}{ Field measurements } \\
\hline Streamflow $\left(\mathrm{ft}^{3} / \mathrm{s}\right)$ & 12 & 129 & 331 & 214.5 \\
\hline Temperature $\left({ }^{\circ} \mathrm{C}\right)$ & 12 & 4.9 & 22.4 & 15.05 \\
\hline $\mathrm{pH}$ (standard units) & 12 & 8.1 & 8.6 & 8.4 \\
\hline Specific conductance $(\mu \mathrm{S} / \mathrm{cm})$ & 12 & 492 & 885 & 540 \\
\hline Dissolved oxygen (mg/L) & 12 & 8.6 & 12.6 & 10.45 \\
\hline \multicolumn{5}{|l|}{ Major ions } \\
\hline Calcium (mg/L) & 12 & 33.1 & 52.6 & 37.95 \\
\hline Magnesium (mg/L) & 12 & 20.4 & 32.6 & 21.45 \\
\hline Sodium, (mg/L) & 12 & 38.2 & 84.9 & 46.4 \\
\hline Potassium, (mg/L) & 12 & 5.97 & 12.1 & 7.22 \\
\hline Chloride (mg/L) & 12 & 12.8 & 29.6 & 14.9 \\
\hline Sulfate $(\mathrm{mg} / \mathrm{L})$ & 12 & 46.8 & 100 & 51.95 \\
\hline Fluoride (mg/L) & 12 & .48 & .83 & .50 \\
\hline Silica $(\mathrm{mg} / \mathrm{L})$ & 12 & 15.6 & 35.0 & 22.55 \\
\hline Alkalinity $\left(\mathrm{mg} / \mathrm{L}\right.$ as $\left.\mathrm{CaCO}_{3}\right)$ & 8 & 182 & 307 & 209 \\
\hline Dissolved solids (mg/L) & 12 & 305 & 560 & 333.5 \\
\hline
\end{tabular}


Table 5. Summary of field measurements and concentrations of inorganic constituents in surface-water samples collected from the four irrigation return-flow drainage basins, Columbia Basin Project, July 2002 through October 2004. —Continued

[Dissolved solids, residue on evaporation, dried at 180 degrees Celsius. Abbreviations: $\mathrm{ft} / \mathrm{s}$, cubic foot per second; ${ }^{\circ} \mathrm{C}$; degrees Celsius; $\mu \mathrm{S} / \mathrm{cm}$, microsiemens per centimeter; $\mathrm{mg} / \mathrm{L}$, milligram per liter; $\mathrm{CaCO}_{3}$, calcium carbonate; $\mu \mathrm{g} / \mathrm{L}$, microgram per liter;

$\mathrm{E}$, estimated (below laboratory reporting level); <, less than]

\begin{tabular}{|c|c|c|c|c|}
\hline \multirow{2}{*}{ Constituent or property } & \multirow{2}{*}{$\begin{array}{c}\text { Number of } \\
\text { samples }\end{array}$} & \multicolumn{3}{|c|}{ Value } \\
\hline & & Minimum & Maximum & Median \\
\hline \multicolumn{5}{|c|}{ Crab Creek—Continued } \\
\hline \multicolumn{5}{|l|}{ Trace elements } \\
\hline Iron $(\mu \mathrm{g} / \mathrm{L})$ & 12 & 5.0 & 27 & 8.5 \\
\hline Manganese ( $\mu \mathrm{g} / \mathrm{L})$ & 12 & 2.3 & 8.3 & 3.6 \\
\hline \multicolumn{5}{|l|}{ Nutrients } \\
\hline Ammonia (mg/L as N) & 12 & $<.010$ & .03 & .010 \\
\hline $\begin{array}{l}\text { Ammonia plus organic nitrogen } \\
(\mathrm{mg} / \mathrm{L} \text { as } \mathrm{N})\end{array}$ & 12 & .04 & .88 & .355 \\
\hline Nitrite plus nitrate (mg/L as $\mathrm{N})$ & 12 & 1.05 & 2.5 & 1.56 \\
\hline Phosphorus (mg/L as $\mathrm{P})$ & 12 & .024 & .099 & .034 \\
\hline Orthophosphate (mg/L as P) & 12 & $<.003$ & .071 & .016 \\
\hline \multicolumn{5}{|c|}{ Lind Coulee } \\
\hline \multicolumn{5}{|l|}{ Field measurements } \\
\hline Streamflow $\left(\mathrm{ft}^{3} / \mathrm{s}\right)$ & 12 & 58 & 355 & 255 \\
\hline Temperature $\left({ }^{\circ} \mathrm{C}\right)$ & 12 & 8.1 & 19.8 & 14.85 \\
\hline $\mathrm{pH}$ (standard units) & 12 & 8.1 & 8.8 & 8.4 \\
\hline Specific conductance $(\mu \mathrm{S} / \mathrm{cm})$ & 12 & 203 & 573 & 292 \\
\hline Dissolved oxygen (mg/L) & 11 & 10.6 & 14.5 & 11.4 \\
\hline \multicolumn{5}{|l|}{ Major ions } \\
\hline Calcium (mg/L) & 12 & 22.5 & 46.9 & 28.45 \\
\hline Magnesium (mg/L) & 12 & 6.56 & 19.6 & 9.69 \\
\hline Sodium, $(\mathrm{mg} / \mathrm{L})$ & 12 & 9.36 & 51.8 & 16.4 \\
\hline Potassium, (mg/L) & 12 & 1.62 & 6.18 & 2.575 \\
\hline Chloride (mg/L) & 12 & 2.95 & 15.7 & 5.4 \\
\hline Sulfate $(\mathrm{mg} / \mathrm{L})$ & 12 & 15.0 & 65.9 & 22.25 \\
\hline Fluoride (mg/L) & 12 & $<.2$ & .7 & .29 \\
\hline Silica $(\mathrm{mg} / \mathrm{L})$ & 12 & 9.49 & 42.6 & 13.4 \\
\hline Alkalinity $\left(\mathrm{mg} / \mathrm{L}\right.$ as $\left.\mathrm{CaCO}_{3}\right)$ & 8 & 81 & 204 & 105.5 \\
\hline Dissolved solids (mg/L) & 12 & 124 & 391 & 186 \\
\hline \multicolumn{5}{|l|}{ Trace elements } \\
\hline Iron $(\mu \mathrm{g} / \mathrm{L})$ & 12 & $<10$ & 16 & 9.0 \\
\hline Manganese $(\mu \mathrm{g} / \mathrm{L})$ & 12 & 5.90 & 21.5 & 14.2 \\
\hline \multicolumn{5}{|l|}{ Nutrients } \\
\hline Ammonia (mg/L as $\mathrm{N})$ & 12 & $<.01$ & .02 & .02 \\
\hline Ammonia plus organic (mg/L as $\mathrm{N})$ & 12 & .15 & .28 & .205 \\
\hline Nitrite plus nitrate $(\mathrm{mg} / \mathrm{L}$ as $\mathrm{N})$ & 12 & .56 & 5.02 & 1.735 \\
\hline Phosphorus (mg/L as $\mathrm{P})$ & 12 & .027 & .079 & .050 \\
\hline Orthophosphate (mg/L as $\mathrm{P})$ & 12 & .017 & .057 & .030 \\
\hline \multicolumn{5}{|c|}{ Red Rock Coulee } \\
\hline \multicolumn{5}{|l|}{ Field measurements } \\
\hline Streamflow $\left(\mathrm{ft}^{3} / \mathrm{s}\right)$ & 12 & 43 & 114 & 71.5 \\
\hline Temperature $\left({ }^{\circ} \mathrm{C}\right)$ & 12 & 4.6 & 23.1 & 16.55 \\
\hline $\mathrm{pH}$ (standard units) & 12 & 8.2 & 8.9 & 8.55 \\
\hline Specific conductance $(\mu \mathrm{S} / \mathrm{cm})$ & 12 & 374 & 660 & 420 \\
\hline Dissolved oxygen (mg/L) & 12 & 8.3 & 12.7 & 9.85 \\
\hline
\end{tabular}


Table 5. Summary of field measurements and concentrations of inorganic constituents in surface-water samples collected from the four irrigation return-flow drainage basins, Columbia Basin Project, July 2002 through October 2004.-Continued

[Dissolved solids, residue on evaporation, dried at 180 degrees Celsius. Abbreviations: $\mathrm{ft}^{3} / \mathrm{s}$, cubic foot per second; ${ }^{\circ} \mathrm{C}$; degrees Celsius; $\mu \mathrm{S} / \mathrm{cm}$, microsiemens per centimeter; $\mathrm{mg} / \mathrm{L}$, milligram per liter; $\mathrm{CaCO}_{3}$, calcium carbonate; $\mu \mathrm{g} / \mathrm{L}$, microgram per liter;

$\mathrm{E}$, estimated (below laboratory reporting level); <, less than]

\begin{tabular}{|c|c|c|c|c|}
\hline \multirow{2}{*}{ Constituent or property } & \multirow{2}{*}{$\begin{array}{c}\text { Number of } \\
\text { samples }\end{array}$} & \multicolumn{3}{|c|}{ Value } \\
\hline & & Minimum & Maximum & Median \\
\hline \multicolumn{5}{|c|}{ Red Rock Coulee-Continued } \\
\hline \multicolumn{5}{|l|}{ Major ions } \\
\hline Calcium (mg/L) & 12 & 21.3 & 53.8 & 37.05 \\
\hline Magnesium (mg/L) & 12 & 16.6 & 29.8 & 18.45 \\
\hline Sodium, $(\mathrm{mg} / \mathrm{L})$ & 12 & 17.8 & 38.6 & 22.1 \\
\hline Potassium, (mg/L) & 12 & 2.02 & 3.55 & 2.705 \\
\hline Chloride $(\mathrm{mg} / \mathrm{L})$ & 12 & 9.03 & 19.3 & 11.0 \\
\hline Sulfate $(\mathrm{mg} / \mathrm{L})$ & 12 & 31.5 & 63.9 & 36.4 \\
\hline Fluoride $(\mathrm{mg} / \mathrm{L})$ & 12 & .3 & .6 & .4 \\
\hline Silica $(\mathrm{mg} / \mathrm{L})$ & 12 & 19.3 & 40.8 & 23.5 \\
\hline Alkalinity $\left(\mathrm{mg} / \mathrm{L}\right.$ as $\left.\mathrm{CaCO}_{3}\right)$ & 8 & 137 & 224 & 155.5 \\
\hline Dissolved solids (mg/L) & 12 & 230 & 411 & 266 \\
\hline \multicolumn{5}{|l|}{ Trace elements } \\
\hline Iron $(\mu \mathrm{g} / \mathrm{L})$ & 12 & $<6.0$ & 6.0 & 5.0 \\
\hline Manganese $(\mu \mathrm{g} / \mathrm{L})$ & 12 & $<2.0$ & 3.4 & 1.8 \\
\hline \multicolumn{5}{|l|}{ Nutrients } \\
\hline Ammonia $(\mathrm{mg} / \mathrm{L}$ as $\mathrm{N})$ & 12 & $<.01$ & .05 & .02 \\
\hline Ammonia plus organic ( $\mathrm{mg} / \mathrm{L}$ as $\mathrm{N})$ & 12 & .20 & .36 & .285 \\
\hline Nitrite plus nitrate (mg/L as $\mathrm{N})$ & 12 & 1.72 & 5.5 & 2.195 \\
\hline Phosphorus $(\mathrm{mg} / \mathrm{L}$ as $\mathrm{P})$ & 12 & .019 & .036 & .023 \\
\hline Orthophosphate (mg/L as $\mathrm{P})$ & 12 & $<.003$ & .016 & .006 \\
\hline \multicolumn{5}{|c|}{ Sand Hollow } \\
\hline \multicolumn{5}{|l|}{ Field measurements } \\
\hline Streamflow $\left(\mathrm{ft}^{3} / \mathrm{s}\right)$ & 12 & 23 & 141 & 92 \\
\hline Temperature $\left({ }^{\circ} \mathrm{C}\right)$ & 12 & 8.1 & 22.0 & 13.7 \\
\hline $\mathrm{pH}$ (standard units) & 12 & 8.1 & 8.6 & 8.45 \\
\hline Specific conductance $(\mu \mathrm{S} / \mathrm{cm})$ & 12 & 141 & 719 & 336.5 \\
\hline Dissolved oxygen (mg/L) & 12 & 8.4 & 12.0 & 10.55 \\
\hline \multicolumn{5}{|l|}{ Major ions } \\
\hline Calcium (mg/L) & 12 & 27.6 & 76.3 & 35.8 \\
\hline Magnesium (mg/L) & 12 & 9.79 & 36.1 & 14.1 \\
\hline Sodium, (mg/L) & 12 & 9.0 & 29.1 & 12.65 \\
\hline Potassium, (mg/L) & 12 & 1.18 & 2.51 & 1.57 \\
\hline Chloride $(\mathrm{mg} / \mathrm{L})$ & 12 & 5.04 & 27.9 & 9.32 \\
\hline Sulfate $(\mathrm{mg} / \mathrm{L})$ & 12 & 16.9 & 66.1 & 25.05 \\
\hline Fluoride $(\mathrm{mg} / \mathrm{L})$ & 12 & .17 & .50 & .23 \\
\hline Silica $(\mathrm{mg} / \mathrm{L})$ & 12 & 9.8 & 43.9 & 17.35 \\
\hline Alkalinity $\left(\mathrm{mg} / \mathrm{L}\right.$ as $\left.\mathrm{CaCO}_{3}\right)$ & 8 & 89 & 106 & 124.5 \\
\hline Dissolved solids (mg/L) & 12 & 167 & 491 & 213.5 \\
\hline \multicolumn{5}{|l|}{ Trace elements } \\
\hline Iron $(\mu \mathrm{g} / \mathrm{L})$ & 12 & $\mathrm{E}_{4}$ & $<10$ & $<6$ \\
\hline Manganese $(\mu \mathrm{g} / \mathrm{L})$ & 12 & E.70 & $\mathrm{E}_{2.5}$ & 1.15 \\
\hline \multicolumn{5}{|l|}{ Nutrients } \\
\hline Ammonia (mg/L as N) & 12 & $<.01$ & .07 & .02 \\
\hline Ammonia plus organic $(\mathrm{mg} / \mathrm{L}$ as $\mathrm{N})$ & 12 & .06 & .45 & .235 \\
\hline Nitrite plus nitrate (mg/L as N) & 12 & 2.46 & 17.9 & 4.515 \\
\hline Phosphorus $(\mathrm{mg} / \mathrm{L}$ as $\mathrm{P})$ & 12 & $<.010$ & .052 & .023 \\
\hline Orthophosphate (mg/L as $\mathrm{P})$ & 12 & $<.003$ & .027 & .006 \\
\hline
\end{tabular}


Dissolved-solids concentrations varied spatially and seasonally. Dissolved-solids concentrations increased during the non-irrigation season and concentrations between sites generally increased as water moved through the CBP, from Lind Coulee down to Crab Creek (fig. 2). Average concentration of dissolved solids at Lind Coulee during this study was $211 \mathrm{mg} / \mathrm{L}$, increasing to an average of $379 \mathrm{mg} / \mathrm{L}$ in samples from Crab Creek. Average concentrations from intermediate sites at Sand Hollow and Red Rock Coulee were 250 and $296 \mathrm{mg} / \mathrm{L}$, respectively. Dissolved-solids concentrations increased during the non-irrigation season, reflecting a larger ground-water contribution to base flow.
Average dissolved-solids concentration at all sites was $249 \mathrm{mg} / \mathrm{L}$ during irrigation season and $454 \mathrm{mg} / \mathrm{L}$ during non-irrigation season.

The predominant major ions from all sites generally were from calcium, magnesium, and bicarbonate (fig. 3). Although some overlap was present between the majorion characteristics of the four sites, each site generally was grouped differently on a major-ion diagram and all were uniquely different from the irrigation source water, represented by the Columbia River. Additionally, samples from Sand Hollow and Lind Coulee during the nonirrigation season were clearly differentiated from samples

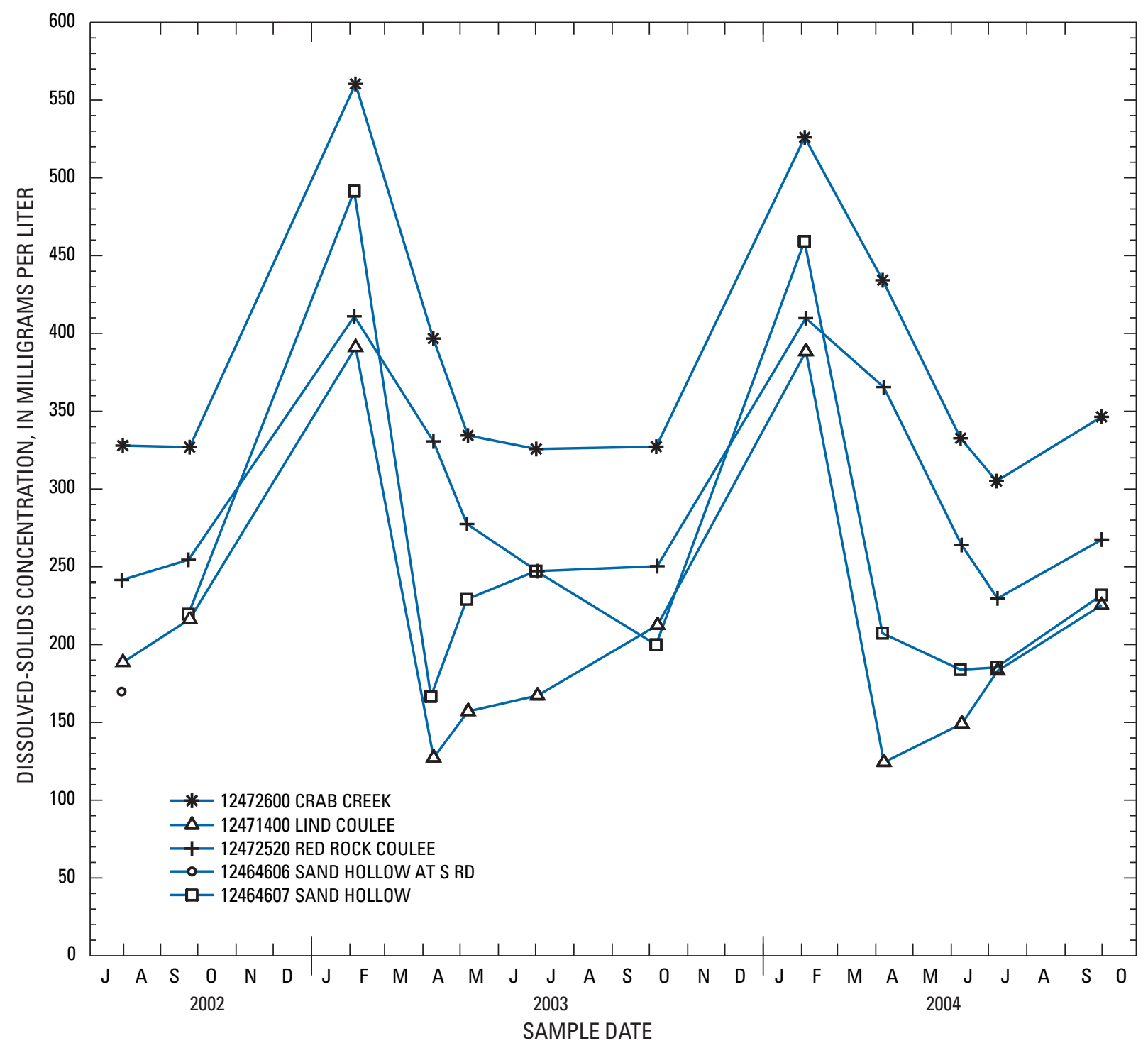

Figure 2. Concentrations of dissolved solids in the four irrigation return-flow drainage basins, Columbia Basin Project, Washington, July 2002 to October 2004.

Site 12464606 was sampled only once in July 2002, and all other samples for Sand Hollow drainage basin were from site 12464607. 


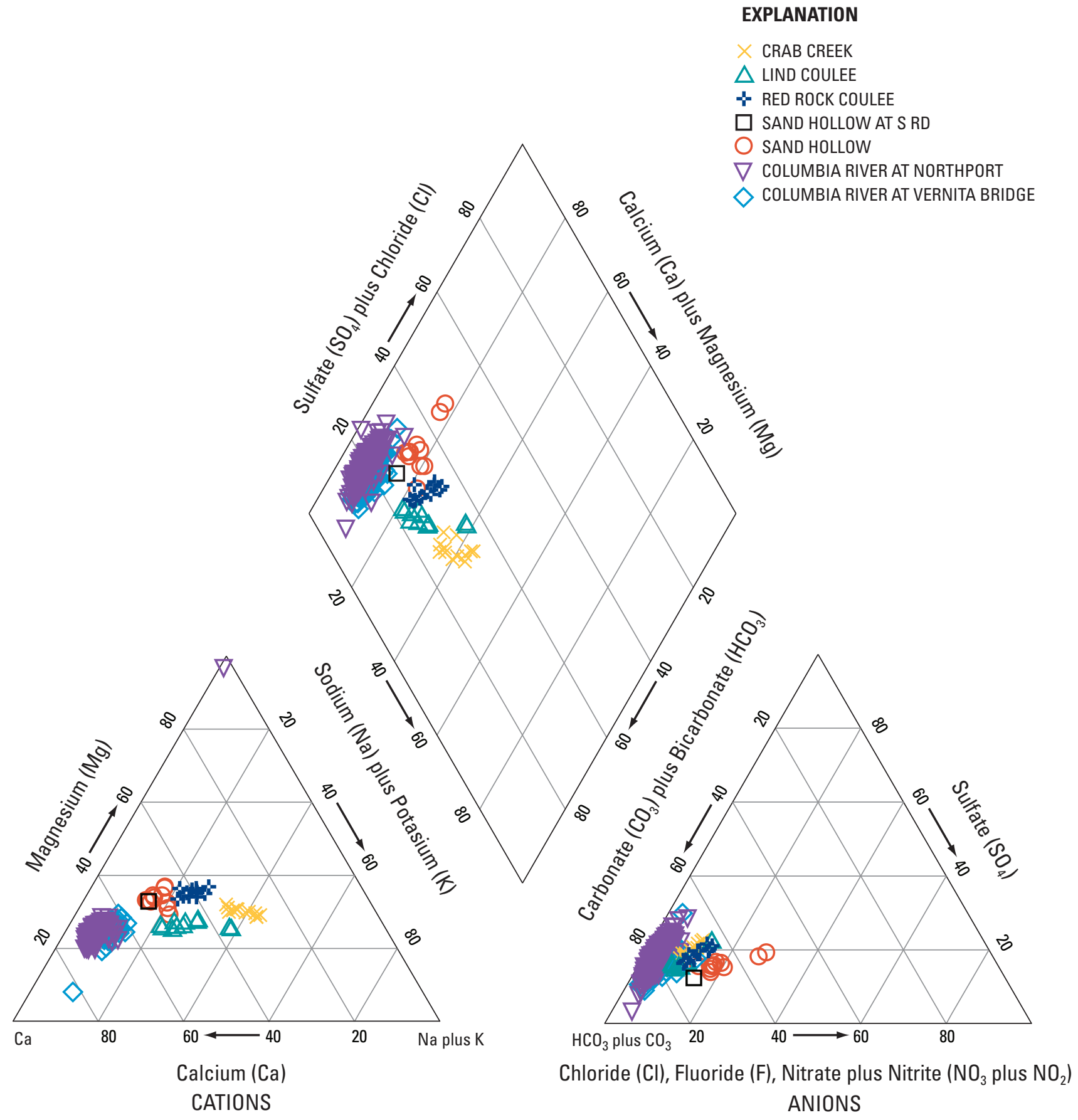

PERCENTAGE OF TOTAL MILLIEQUIVALENTS PER LITER

Figure 3. Percentage of major ions in surface water from the Columbia River and from the four irrigation return-flow drainage basins, Columbia Basin Project, Washington. 
collected during the irrigation season. Anions for all samples were predominantly from bicarbonate and cations were predominantly from calcium. During the irrigation season, calcium was the predominant cation for both sites. However, during the non-irrigation, concentrations of chloride and nitrate increased in samples from Sand Hollow and reflect a shift in the percentage of chloride, fluoride, and nitrite plus nitrate. Similarly, the percentage of sulfate plus chloride for Sand Hollow also increased during the non-irrigation season. Samples from Lind Coulee during the non-irrigation season also are readily differentiated from irrigation season samples because of an increase in sodium plus potassium during the non-irrigation season. However, the percentage of nitrite plus nitrate for samples from Sand Hollow nearly doubled during the non-irrigation season and the percentages of sulfate and chloride increased. Similarly, samples from Lind Coulee during the non-irrigation season were clearly differentiated from samples collected during the irrigation season because of a shift in the cation percentages, with less calcium and more sodium.

Generally, the ratio of dissolved solids divided by specific conductance is a well-defined relation (Hem, 1985) for many rivers and streams. Because no long-term data for irrigation source water (from Lake Roosevelt or Banks Lake) are publicly available, historical information for the Columbia River above Lake Roosevelt (at Northport, Wash.) and downstream of Lake Roosevelt (near Priest Rapids Dam) can be used to approximate the quality of irrigation source water. The median ratio of dissolved solids to specific conductance ranges from 0.58 to 0.64 for the sites in the four irrigation return-flow basins and the Columbia River sites (table 6). However, the relation between silica and calcium provides an even better "signature" of major ions in the irrigation return flow (table 17). The long-term median silica-calcium ratios for the sites at Columbia River at Northport and Priest Rapids Dam are 0.23 and 0.26 , respectively. As the irrigation water flows through the CBP, the ratio in samples increases, reflected by the higher ratios. Although ranges of the ratio overlap, each individual sample ratio was uniquely different from the others during that sampling period. Major-ion, trace-element, and nutrient concentrations generally were within State and Federal criteria. Concentrations of nitrite plus nitrate in two samples collected from Sand Hollow during the non-irrigation season exceeded the U.S. Environmental Protection Agency (USEPA) Maximum Contaminant Level (MCL) for drinking water of $10 \mathrm{mg} / \mathrm{L}$.

Table 6. Summary of calculated major ion ratios in surface-water samples collected from the four irrigation return-flow drainage basins, Columbia Basin Project, and the Columbia River, Washington, July 2002 to October 2004.

[Columbia River data are from 1960-2000. The Sand Hollow sites were combined for analysis. Abbreviations: $\mathrm{SiO}_{2} / \mathrm{Ca}$ : ratio of silica and calcium; Dissolved solids/SC, ratio of dissolved solids and specific conductance in microsiemens per centimeter at 25 degrees Celsius]

\begin{tabular}{|c|c|c|c|c|c|c|}
\hline Sampling site & \multicolumn{3}{|c|}{$\mathrm{SiO}_{2} / \mathrm{Ca}$} & \multicolumn{3}{|c|}{ Dissolved solids/SC } \\
\hline Crab Creek & 0.44 & 0.69 & 0.59 & 0.60 & 0.66 & 0.62 \\
\hline Red Rock Coulee & .53 & .76 & .64 & .57 & .68 & .62 \\
\hline Sand Hollow & .36 & .58 & .49 & .57 & .70 & .62 \\
\hline
\end{tabular}




\section{Occurrence and Distribution of Pesticides}

Forty-two pesticides and five metabolites were detected in samples from the four irrigation return-flow drainage basins in the CBP from July 2002 to October 2004 (table 7). The greatest number of compounds, 37, was detected at Sand Hollow, followed by 33 at Lind Coulee, 30 at Red Rock Coulee, and 28 at Crab Creek. Herbicides were the most frequently detected pesticides, followed by insecticides, metabolites, and fungicides. Atrazine, bentazon, diuron, and 2,4-D were the most frequently detected herbicides, and chlorpyrifos and azinphos-methyl were the most frequently detected insecticides. Of the five metabolites detected, four were degradation products of triazine herbicides and one was the degradation product of DCPA (dacthal monoacid). CIAT (commonly referred to as deethylatrazine), CEAT, CAAT, and OIET were the most frequently detected metabolites.

Pesticide concentrations in samples from the CBP did not exceed any drinking-water standards or guidelines, but concentrations of three insecticides and one herbicide did exceed USEPA or Canadian freshwater aquatic-life benchmarks (table 8). Concentrations of the insecticide azinphos-methyl exceeded USEPA recommended chronic water-quality criterion for the protection of freshwater aquatic life of $0.01 \mu \mathrm{g} / \mathrm{L}$ at least once at each of the four sites. Concentrations in samples from Sand Hollow also exceeded USEPA recommended freshwater chronic criterion for the protection of freshwater aquatic life for chlorpyrifos (0.041), and Canadian guidelines for the protection of freshwater aquatic life for lindane and dinoseb $(0.01$, and $0.05 \mu \mathrm{g} / \mathrm{L}$, respectively). Water-quality aquatic-life benchmarks generally were exceeded in June and July, during the middle of the irrigation season, except the criterion for dinoseb, which was exceeded in one sample during non-irrigation season in February 2003, at a concentration of $0.14 \mu \mathrm{g} / \mathrm{L}$.

Pesticides can be toxic to aquatic life in streams, and the ECOTOX (ECOTOXicology) database (U.S. Environmental Protection Agency, 2005a) provides single-chemical toxicity information for aquatic freshwater life (table 9). Data retrieved from ECOTOX contained a substantial number of apparent duplicate entries (Munn and Gilliom, 2001, and Patrick Moran, U.S. Geological Survey, oral commun., November 2005), and these were removed. Because of the complex mixtures and seasonal patterns of pesticides, it is difficult to link chemical conditions in streams to effects on aquatic biota (Munn and Gilliom, 2001). The endpoint concentration for comparison of aquatic toxicity to fish used in this study is median lethal concentrations $\left(\mathrm{LC}_{50}\right)$, which is a statistically estimated concentration that is expected to be lethal to 50 percent of a group of organisms tested. $\mathrm{LC}_{50}$ for all pesticides analyzed during this study are far greater than concentrations detected in samples collected from irrigation-return flows during this study. However, data are not available for all pesticides, and additive or possible synergistic effects of multiple chemicals are not accounted for by this measure of aquatic toxicity. The most toxic insecticides analyzed during this study are azinphos-methyl, chlorpyrifos, lindane, and malathion, with $\mathrm{LC}_{50}$ values that range from 1.3 to $2.4 \mu \mathrm{g} / \mathrm{L}$. Concentrations of pesticides analyzed during this study are far less than these $\mathrm{LC}_{50}$ concentrations. The most toxic herbicides were trifluralin, pendimethalin, ethalfluvalin, and diacamba, with $\mathrm{LC}_{50}$ values that range from 8.4 to $138 \mu \mathrm{g} / \mathrm{L}$. $\mathrm{LC}_{50}$ values for specific pesticides are a factor of 110 greater than maximum concentrations of pesticides detected in samples from the four drainage basins during this study. Munn and Gilliom (2001) suggest use of a pesticide toxicity index (PTI), which is the sum of toxicity quotients for each compound measured in a stream. This approach may be useful in relating pesticide toxicity between drainage basins and over time, but it is beyond the scope of this study.

Total number of pesticide detections and total concentrations of those detections show a distinct seasonal pattern at the four sites, with the highest number of detections and total concentrations during the middle of the irrigation season, April to October (fig. 4). Samples from Sand Hollow basin generally had the greatest number of pesticides per sample, ranging from about 8 pesticides detected in a sample during the end of irrigation season to more than 20 pesticides detected in samples collected during the middle of irrigation season. Samples from Lind Coulee basin had the fewest number of pesticides per sample, ranging from 4 to 18 pesticides with the highest number also occurring during the middle of irrigation season.

The pattern for total pesticides concentrations for Sand Hollow basin was slightly different than those for the other three basins, with a substantially higher total concentration in the sample collected during the 2003 non-irrigation season. This may be an aberration that occurred only in 2003, but it likely is due to the increase in concentrations of atrazine, CIAT, bentazon, and bromacil during base-flow conditions in the non-irrigation season. Total pesticide concentrations in the sample collected during the 2004 non-irrigation season were higher than those in late-irrigation season samples, but it is not clear why the 2003 non-irrigation sample was substantially higher. The increase in concentration of these compounds during base flow indicates that ground water contributes a substantial part of the pesticide load for these compounds. Further study of pesticides in the irrigation return-flow drainage basins during the non-irrigation season would be helpful. 
Table 7. Maximum concentrations and number of pesticide detections in the four irrigation return-flow drainage basins, Columbia Basin Project, Washington, July 2002 to October 2004.

[All concentrations are in micrograms per liter. Concentrations in bold represent values that exceed freshwater aquatic-life benchmarks (see table 4). Pesticide: CIAT, 2-chloro-4-isopropylamino-6-amino-s-triazine; CEAT, 2-chloro-6-ethylamino-4-amino-s-tirazine; CAAT, chlorodiamino-s-triazine; OIET, 2-hydroxy4-isopropylamino-t-ethylamino-s-triazine. Type of pesticide: $\mathrm{F}$, fungicide; $\mathrm{H}$, herbicide; I, insecticide; $\mathrm{S}$, stimulant; T, transformation product. Number of detections: All, sum of all detections at all surface-water sites. Abbreviations: LRL, laboratory reporting level; SH, Sand Hollow; LCWA, Lind Coulee; CRCR, Crab Creek; RRCU, Red Rock Coulee; M, presence of material verified but not quantified; ${ }^{\text {, }}$, because recovery or variation in recovery was outside the acceptable range, compound is qualified with an E-code (estimated) or concentration reported is less than laboratory reporting level and is qualified as estimated; ,- not detected]

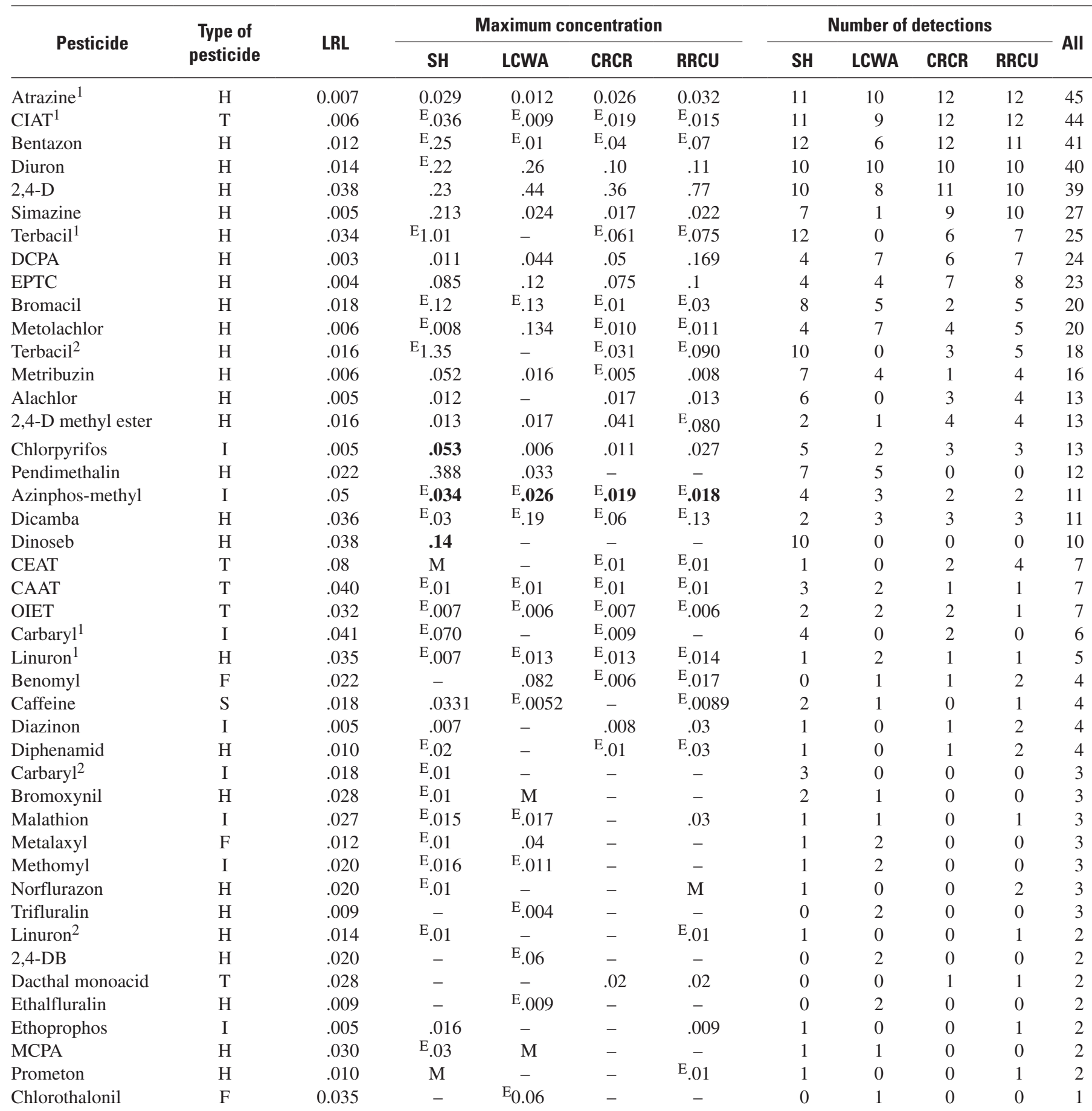


Table 7. Maximum concentrations and number of pesticide detections in the four irrigation return-flow drainage basins, Columbia Basin Project, Washington, July 2002 to October 2004.-Continued

[All concentrations are in micrograms per liter. Concentrations in bold represent values that exceed freshwater aquatic-life benchmarks (see table 4). Pesticide: CIAT, 2-chloro-4-isopropylamino-6-amino-s-triazine; CEAT, 2-chloro-6-ethylamino-4-amino-s-tirazine; CAAT, chlorodiamino-s-triazine; OIET, 2-hydroxy4-isopropylamino-t-ethylamino-s-triazine. Type of pesticide: $\mathrm{F}$, fungicide; $\mathrm{H}$, herbicide; I, insecticide; S, stimulant; T, transformation product. Number of detections: All, sum of all detections at all surface-water sites. Abbreviations: LRL, laboratory reporting level; SH, Sand Hollow; LCWA, Lind Coulee; CRCR, Crab Creek; RRCU, Red Rock Coulee; M, presence of material verified but not quantified; E , because recovery or variation in recovery was outside the acceptable range, compound is qualified with an E-code (estimated) or concentration reported is less than laboratory reporting level and is qualified as estimated; ,- not detected]

\begin{tabular}{|c|c|c|c|c|c|c|c|c|c|c|c|}
\hline Pesticide & $\begin{array}{c}\text { Type of } \\
\text { pesticide }\end{array}$ & LRL & \multicolumn{4}{|c|}{ Maximum concentration } & \multicolumn{4}{|c|}{ Number of detections } & All \\
\hline Clopyralid & $\mathrm{H}$ & .024 & - & - & $\mathrm{E}_{0.01}$ & - & 0 & 0 & 1 & 0 & 1 \\
\hline Nicosulfuron & $\mathrm{H}$ & .04 & - & - & E.01 & - & 0 & 0 & 1 & 0 & 1 \\
\hline Oxamyl & I & .030 & - & .03 & - & - & 0 & 1 & 0 & 0 & 1 \\
\hline Propiconazole & $\mathrm{F}$ & .010 & - & ${ }^{\mathrm{E}} .01$ & - & - & 0 & 1 & 0 & 0 & 1 \\
\hline Triclopyr & \multicolumn{6}{|c|}{ Number of samples analyzed } & 12 & 12 & 12 & 12 & 48 \\
\hline
\end{tabular}

${ }^{1}$ Analysis by gas chromatography/mass spectrometry (GC/MS).

${ }^{2}$ Analysis by high-performance liquid chromatography/mass spectrometry (HPLC/MS).

Table 8. Summary of pesticide concentrations in the four irrigation return-flow drainage basins, Columbia Basin Project, Washington, July 2002 to October 2004.

[All concentrations are in micrograms per liter. Concentrations of pesticides in bold represent values that exceed freshwater aquatic-life benchmarks (see table 4). Pesticide: CIAT, 2-chloro-4-isopropylamino-6-amino-s-triazine; CAAT, chlorodiamino-s-triazine; OIET, 2-hydroxy-4-isoprobylamino-6-ethylamino-striazine; CEAT, 2-chloro-6-ethylamino-4-amino-s-triazine. Type of pesticide: $\mathrm{F}$, fungicide; $\mathrm{H}$, herbicide; I, insecticide; S, stimulant; T, transformation product. Drinking-water standards: Maximum contaminant levels for drinking water from U.S. Environmental Protection Agency (2004a). Freshwater aquatic-life benchmarks: Standards from U.S. Environmental Protection Agency (2004b), unless otherwise footnoted. Abbreviations: LRL, laboratory reporting limit; M, presence of material verified, but not quantified; $n$, number of samples; ${ }^{\mathrm{E}}$, because recovery or variation in recovery was outside the acceptable range, compound is qualified with an E-code (estimated) or concentration reported is less than laboratory reporting level and is qualified as estimated; <, less than; -, no data or not available; *, interim values (Canadian Council of Resources and Environment Ministers, 1997)]

\begin{tabular}{|c|c|c|c|c|c|c|c|}
\hline Pesticide & $\begin{array}{c}\text { Type of } \\
\text { pesticide }\end{array}$ & LRL & Median & Maximum & $\begin{array}{c}\text { Percentage } \\
\text { of } \\
\text { detections } \\
(n=12)\end{array}$ & $\begin{array}{l}\text { Number of } \\
\text { detections } \\
\text { that exceed } \\
\text { aquatic-life } \\
\text { benchmarks }\end{array}$ & $\begin{array}{l}\text { Number of } \\
\text { detections } \\
\text { that exceed } \\
\text { drinking } \\
\text { water } \\
\text { standards }\end{array}$ \\
\hline \multicolumn{8}{|c|}{ Crab Creek } \\
\hline Atrazine & $\mathrm{H}$ & .007 & .018 & .026 & 100 & 0 & 0 \\
\hline Bentazon & $\mathrm{H}$ & .012 & ${ }^{\mathrm{E}} .02$ & ${ }^{\mathrm{E}} .04$ & 100 & - & - \\
\hline 2,4-D & $\mathrm{H}$ & .038 & .06 & .36 & 92 & 0 & - \\
\hline Diuron & $\mathrm{H}$ & .014 & .02 & .1 & 83 & - & - \\
\hline Simazine & $\mathrm{H}$ & .005 & .007 & .017 & 75 & - & 0 \\
\hline EPTC & $\mathrm{H}$ & .004 & ${ }^{\mathrm{E}} .002$ & .075 & 58 & - & - \\
\hline Alachlor & $\mathrm{H}$ & .006 & $<.004$ & .017 & 25 & - & 0 \\
\hline Chlorpyrifos & I & .005 & $<.005$ & .011 & 25 & 0 & 0 \\
\hline Dicamba & $\mathrm{H}$ & .036 & $<.01$ & ${ }^{\mathrm{E}} .06$ & 25 & 0 & 0 \\
\hline Terbacil $^{2}$ & $\mathrm{H}$ & .016 & $<.010$ & ${ }^{\mathrm{E}} .031$ & 25 & - & 0 \\
\hline
\end{tabular}


Table 8. Summary of pesticide concentrations in the four irrigation return-flow drainage basins, Columbia Basin Project, Washington, July 2002 to October 2004.-Continued

[All concentrations are in micrograms per liter. Concentrations of pesticides in bold represent values that exceed freshwater aquatic-life benchmarks (see table 4). Pesticide: CIAT, 2-chloro-4-isopropylamino-6-amino-s-triazine; CAAT, chlorodiamino-s-triazine; OIET, 2-hydroxy-4-isoprobylamino-6-ethylamino-striazine; CEAT, 2-chloro-6-ethylamino-4-amino-s-triazine. Type of pesticide: $\mathrm{F}$, fungicide; $\mathrm{H}$, herbicide; I, insecticide; S, stimulant; T, transformation product. Drinking-water standards: Maximum contaminant levels for drinking water from U.S. Environmental Protection Agency (2004a). Freshwater aquatic-life benchmarks: Standards from U.S. Environmental Protection Agency (2004b), unless otherwise footnoted. Abbreviations: LRL, laboratory reporting limit; M, presence of material verified, but not quantified; $n$, number of samples; ${ }^{\mathrm{E}}$, because recovery or variation in recovery was outside the acceptable range, compound is qualified with an E-code (estimated) or concentration reported is less than laboratory reporting level and is qualified as estimated; <, less than; -, no data or not available; *, interim values (Canadian Council of Resources and Environment Ministers, 1997)]

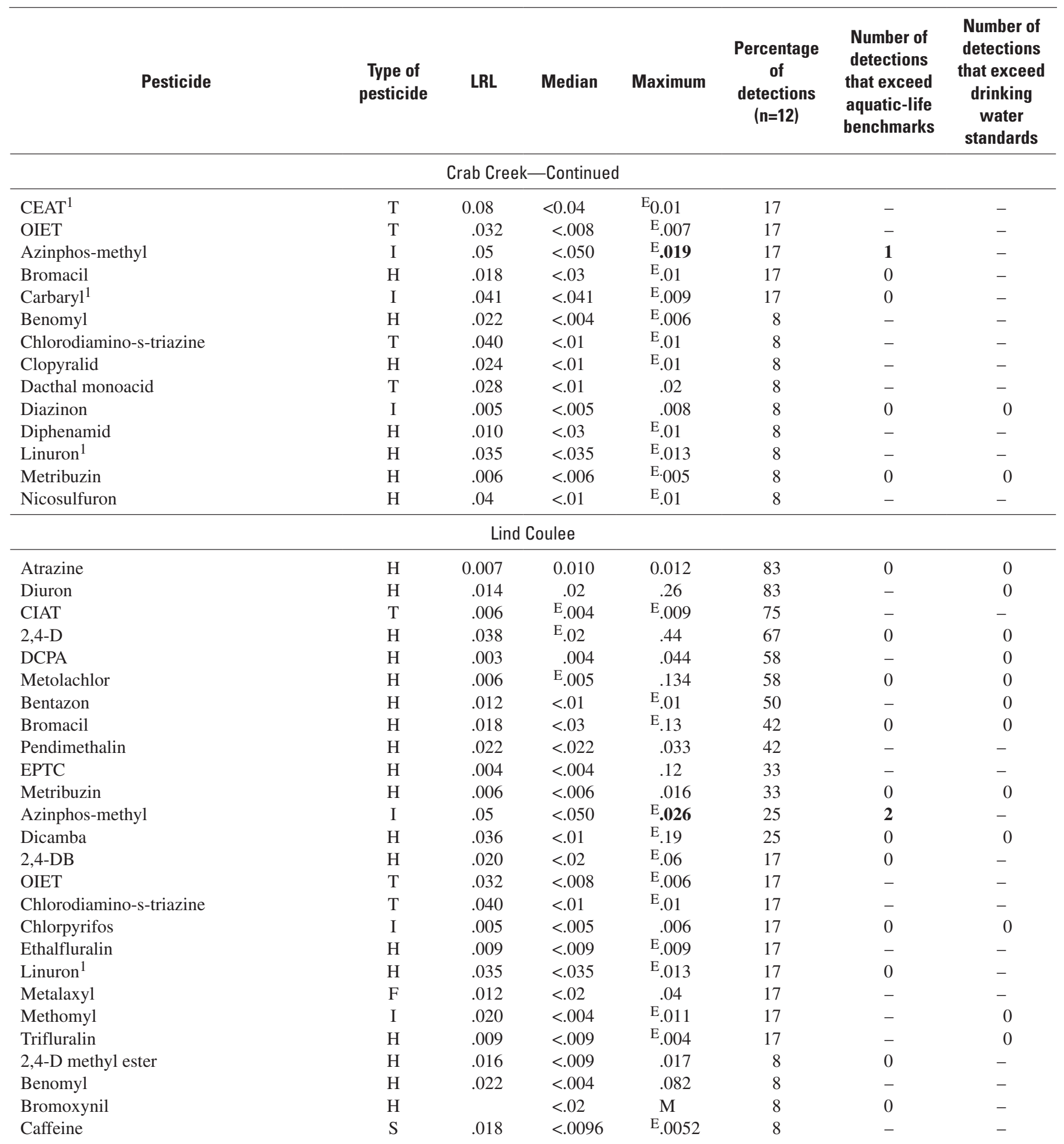


Table 8. Summary of pesticide concentrations in the four irrigation return-flow drainage basins, Columbia Basin Project, Washington, July 2002 to October 2004.-Continued

[All concentrations are in micrograms per liter. Concentrations of pesticides in bold represent values that exceed freshwater aquatic-life benchmarks (see table 4). Pesticide: CIAT, 2-chloro-4-isopropylamino-6-amino-s-triazine; CAAT, chlorodiamino-s-triazine; OIET, 2-hydroxy-4-isoprobylamino-6-ethylamino-striazine; CEAT, 2-chloro-6-ethylamino-4-amino-s-triazine. Type of pesticide: $\mathrm{F}$, fungicide; $\mathrm{H}$, herbicide; I, insecticide; S, stimulant; T, transformation product. Drinking-water standards: Maximum contaminant levels for drinking water from U.S. Environmental Protection Agency (2004a). Freshwater aquatic-life benchmarks: Standards from U.S. Environmental Protection Agency (2004b), unless otherwise footnoted. Abbreviations: LRL, laboratory reporting limit; M, presence of material verified, but not quantified; $n$, number of samples; ${ }^{\mathrm{E}}$, because recovery or variation in recovery was outside the acceptable range, compound is qualified with an E-code (estimated) or concentration reported is less than laboratory reporting level and is qualified as estimated; <, less than; -, no data or not available; *, interim values (Canadian Council of Resources and Environment Ministers, 1997)]

\begin{tabular}{|c|c|c|c|c|c|c|c|}
\hline Pesticide & $\begin{array}{c}\text { Type of } \\
\text { pesticide }\end{array}$ & LRL & Median & Maximum & $\begin{array}{c}\text { Percentage } \\
\text { of } \\
\text { detections } \\
\quad(n=12)\end{array}$ & $\begin{array}{l}\text { Number of } \\
\text { detections } \\
\text { that exceed } \\
\text { aquatic-life } \\
\text { benchmarks }\end{array}$ & $\begin{array}{c}\text { Number of } \\
\text { detections } \\
\text { that exceed } \\
\text { drinking } \\
\text { water } \\
\text { standards }\end{array}$ \\
\hline \multicolumn{8}{|c|}{ Lind Coulee-Continued } \\
\hline Malathion & I & .027 & $<.027$ & E.017 & 8 & 0 & 0 \\
\hline MCPA & $\mathrm{H}$ & .030 & $<.02$ & M & 8 & 0 & 0 \\
\hline Oxamyl & I & .030 & $<.01$ & .03 & 8 & - & - \\
\hline Propiconazole & $\mathrm{F}$ & .010 & $<.02$ & ${ }^{\mathrm{E}} .01$ & 8 & - & - \\
\hline Simazine & $\mathrm{H}$ & .005 & $<.005$ & .024 & 8 & - & 0 \\
\hline Triallate & $\mathrm{H}$ & .002 & $<.002$ & .004 & 8 & - & - \\
\hline Atrazine & $\mathrm{H}$ & .007 & .019 & .032 & 100 & 0 & 0 \\
\hline Bentazon & $\mathrm{H}$ & .012 & $\mathrm{E}_{.04}$ & E.07 & 92 & - & 0 \\
\hline $2,4-\mathrm{D}$ & $\mathrm{H}$ & .038 & .09 & .77 & 83 & 0 & 0 \\
\hline Diuron & $\mathrm{H}$ & .014 & .02 & .11 & 83 & - & 0 \\
\hline Simazine & $\mathrm{H}$ & .005 & .011 & .022 & 83 & - & 0 \\
\hline EPTC & $\mathrm{H}$ & .004 & ${ }^{\mathrm{E}} .003$ & .1 & 67 & - & - \\
\hline DCPA & $\mathrm{H}$ & .003 & ${ }^{\mathrm{E}} .003$ & .169 & 58 & - & - \\
\hline Terbacil1 & $\mathrm{H}$ & .034 & $\mathrm{E}_{.012}$ & ${ }^{\mathrm{E}} .075$ & 58 & - & 0 \\
\hline 2,4-D methyl ester & $\mathrm{H}$ & .016 & .014 & ${ }^{\mathrm{E}} .080$ & 50 & 0 & - \\
\hline Bromacil & $\mathrm{H}$ & .018 & $<.03$ & E.03 & 42 & 0 & - \\
\hline Metolachlor & $\mathrm{H}$ & .006 & $<.013$ & $\mathrm{E}_{.011}$ & 42 & 0 & 0 \\
\hline Terbacil $^{2}$ & $\mathrm{H}$ & .016 & $<.027$ & ${ }^{\mathrm{E}} .090$ & 42 & - & 0 \\
\hline Diazinon & I & .005 & $<.005$ & .03 & 17 & 0 & 0 \\
\hline Diphenamid & $\mathrm{H}$ & .010 & $<.03$ & E.03 & 17 & - & 0 \\
\hline Norflurazon & $\mathrm{H}$ & .020 & $<.02$ & M & 17 & - & - \\
\hline OIET & $\mathrm{T}$ & .032 & $<.008$ & E.006 & 8 & - & - \\
\hline Caffeine & $\mathrm{S}$ & .018 & $<.0096$ & E.0089 & 8 & - & - \\
\hline Chlorodiamino-s-triazine & $\mathrm{T}$ & .040 & $<.01$ & E .01 & 8 & - & - \\
\hline Dacthal monoacid & $\mathrm{T}$ & 0.028 & $<0.01$ & 0.02 & 8 & - & - \\
\hline Ethoprophos & I & .005 & $<.005$ & .009 & 8 & - & - \\
\hline Linuron $^{2}$ & $\mathrm{H}$ & .014 & $<.01$ & $\mathrm{E}_{.01}$ & 8 & 0 & - \\
\hline Linuron $^{1}$ & $\mathrm{H}$ & .035 & $<.035$ & ${ }^{\mathrm{E}} .014$ & 8 & 0 & - \\
\hline Malathion & I & .027 & $<.027$ & .03 & 8 & 0 & 0 \\
\hline Prometon & $\mathrm{H}$ & .010 & $<.01$ & E. 01 & 8 & - & 0 \\
\hline
\end{tabular}


Table 8. Summary of pesticide concentrations in the four irrigation return-flow drainage basins, Columbia Basin Project, Washington, July 2002 to October 2004.-Continued

[All concentrations are in micrograms per liter. Concentrations of pesticides in bold represent values that exceed freshwater aquatic-life benchmarks (see table 4). Pesticide: CIAT, 2-chloro-4-isopropylamino-6-amino-s-triazine; CAAT, chlorodiamino-s-triazine; OIET, 2-hydroxy-4-isoprobylamino-6-ethylamino-striazine; CEAT, 2-chloro-6-ethylamino-4-amino-s-triazine. Type of pesticide: $\mathrm{F}$, fungicide; $\mathrm{H}$, herbicide; I, insecticide; S, stimulant; T, transformation product. Drinking-water standards: Maximum contaminant levels for drinking water from U.S. Environmental Protection Agency (2004a). Freshwater aquatic-life benchmarks: Standards from U.S. Environmental Protection Agency (2004b), unless otherwise footnoted. Abbreviations: LRL, laboratory reporting limit; M, presence of material verified, but not quantified; $n$, number of samples; ${ }^{\mathrm{E}}$, because recovery or variation in recovery was outside the acceptable range, compound is qualified with an E-code (estimated) or concentration reported is less than laboratory reporting level and is qualified as estimated; <, less than; -, no data or not available; *, interim values (Canadian Council of Resources and Environment Ministers, 1997)]

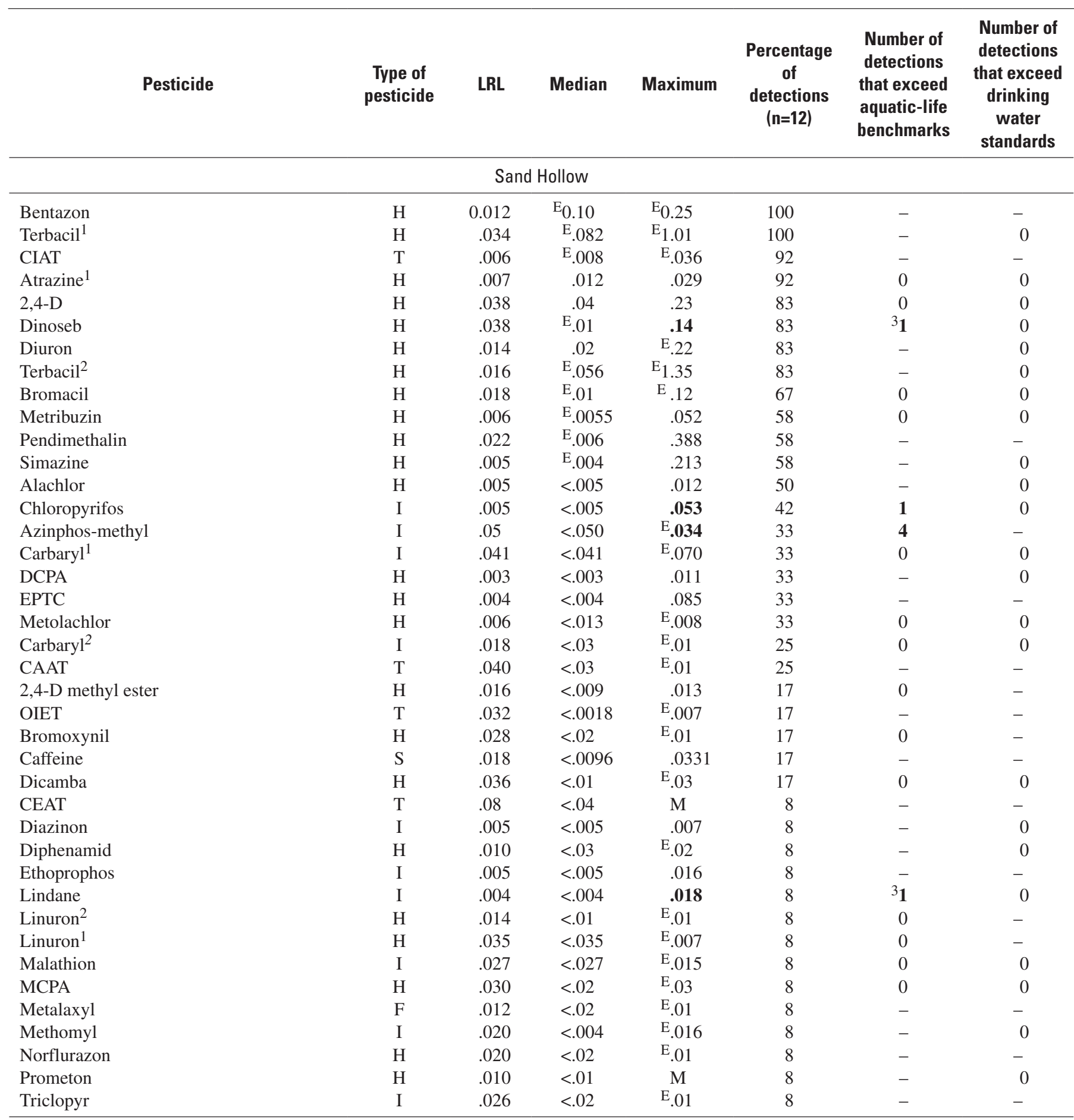

${ }^{1}$ Analysis by gas chromatography/mass spectrometry (GC/MS).

${ }^{2}$ Analysis by high-performance liquid chromatography/mass spectrometry (HPLC/MS).

${ }^{3}$ Canadian water-quality guidelines for the protection of freshwater aquatic life (Canadian Council of Ministers of the Environment, 2003). 
24 Pesticides in Agricultural Irrigation-Return Flow, Columbia Basin Project, Washington, 2002-04

Table 9. Summary of pesticide toxicity values for freshwater fish in the Columbia Basin Project, Washington.

[All concentrations are lethal concentrations for 50 percent of the target species $\left(\mathrm{LC}_{50}\right)$ at 96 hours, in micrograms per liter. All data are compiled from the U.S. Environmental Protection Agency ECOTOX database (U.S. Environmental Protection Agency, 2005a). Abbreviations: N, number of references for specific studies; CAS, Chemical Abstract Services; - . not available]

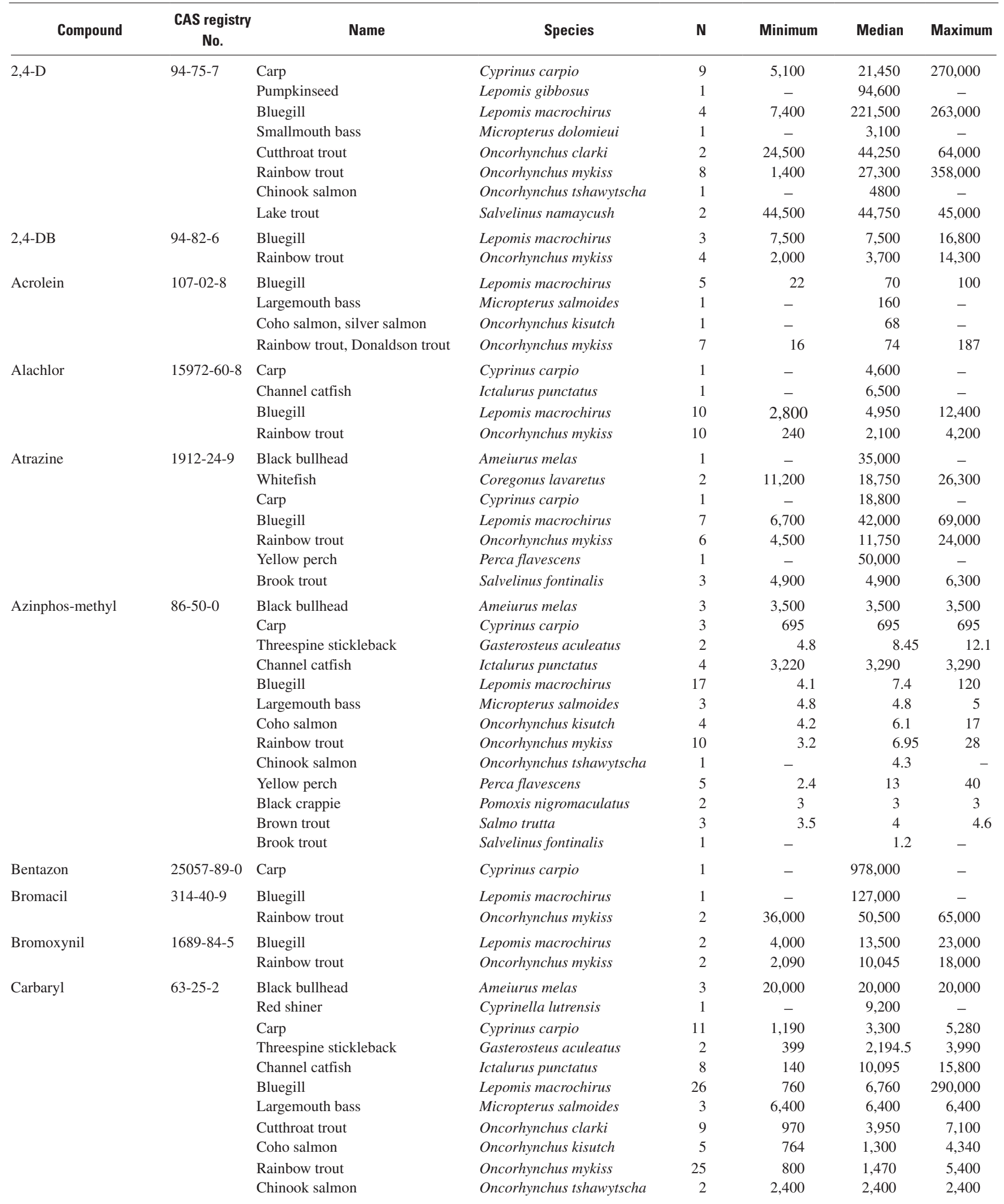


Table 9. Summary of pesticide toxicity values for freshwater fish in the Columbia Basin Project, Washington._-Continued

[All concentrations are lethal concentrations for 50 percent of the target species $\left(\mathrm{LC}_{50}\right)$ at 96 hours, in micrograms per liter. All data are compiled from the U.S. Environmental Protection Agency ECOTOX database (U.S. Environmental Protection Agency, 2005a). Abbreviations: N, number of references for specific studies; CAS, Chemical Abstract Services]

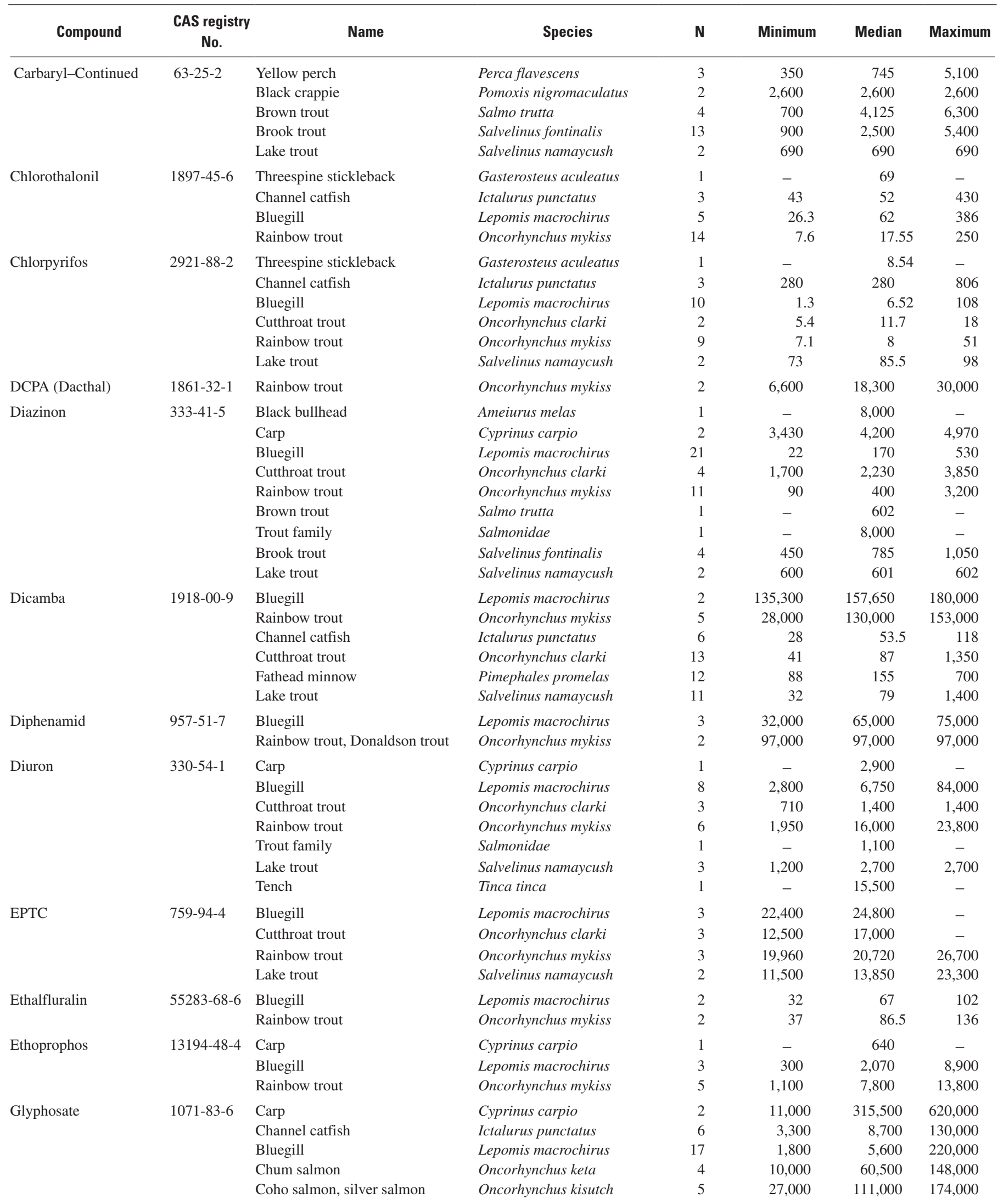


Table 9. Summary of pesticide toxicity values for freshwater fish in the Columbia Basin Project, Washington._Continued

[All concentrations are lethal concentrations for 50 percent of the target species $\left(\mathrm{LC}_{50}\right)$ at 96 hours, in micrograms per liter. All data are compiled from the U.S. Environmental Protection Agency ECOTOX database (U.S. Environmental Protection Agency, 2005a). Abbreviations: N, number of references for specific studies; CAS, Chemical Abstract Services]

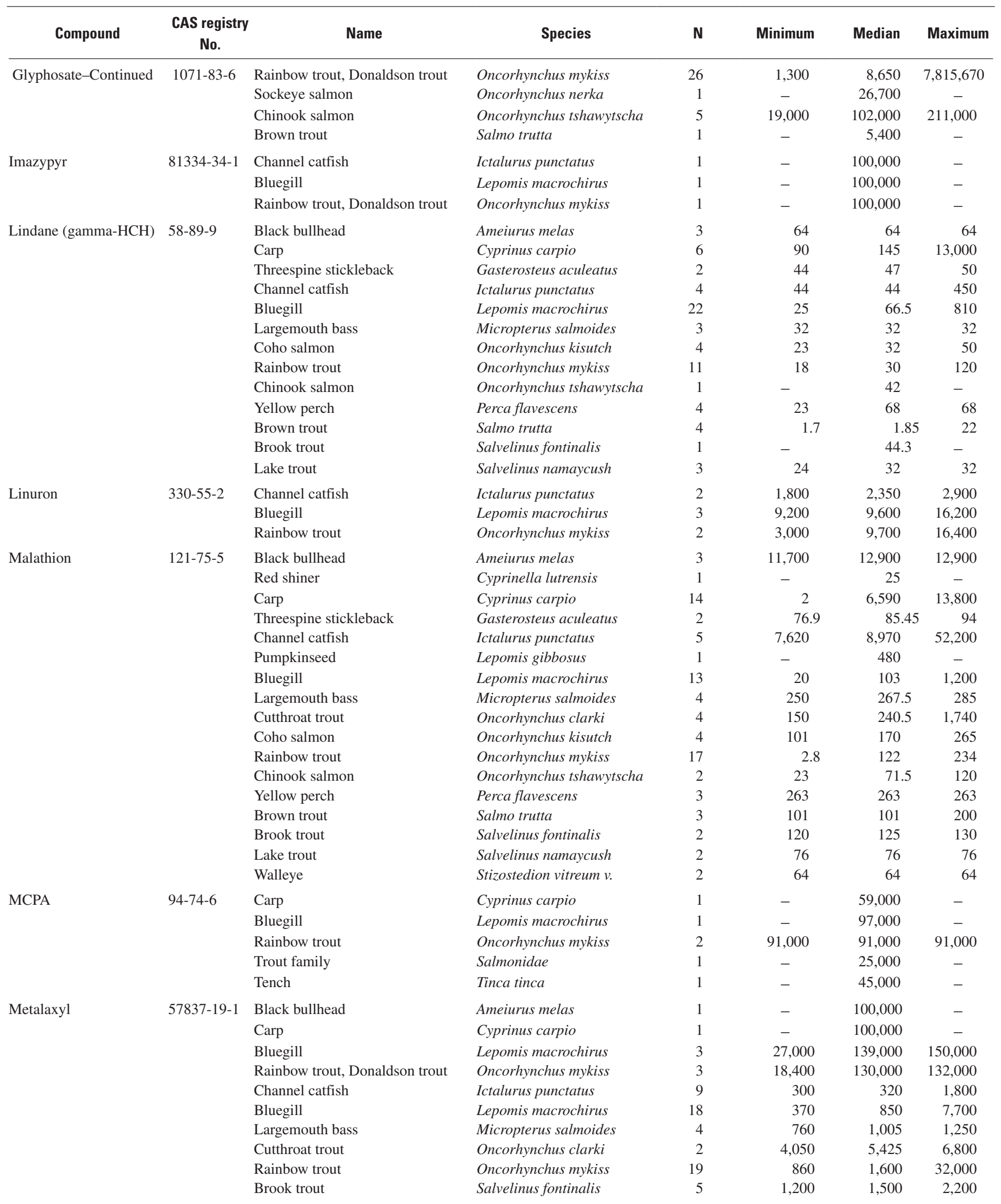


Table 9. Summary of pesticide toxicity values for freshwater fish in the Columbia Basin Project, Washington._Continued

[All concentrations are lethal concentrations for 50 percent of the target species $\left(\mathrm{LC}_{50}\right)$ at 96 hours, in micrograms per liter. All data are compiled from the U.S. Environmental Protection Agency ECOTOX database (U.S. Environmental Protection Agency, 2005a). Abbreviations: N, number of references for specific studies; CAS, Chemical Abstract Services]

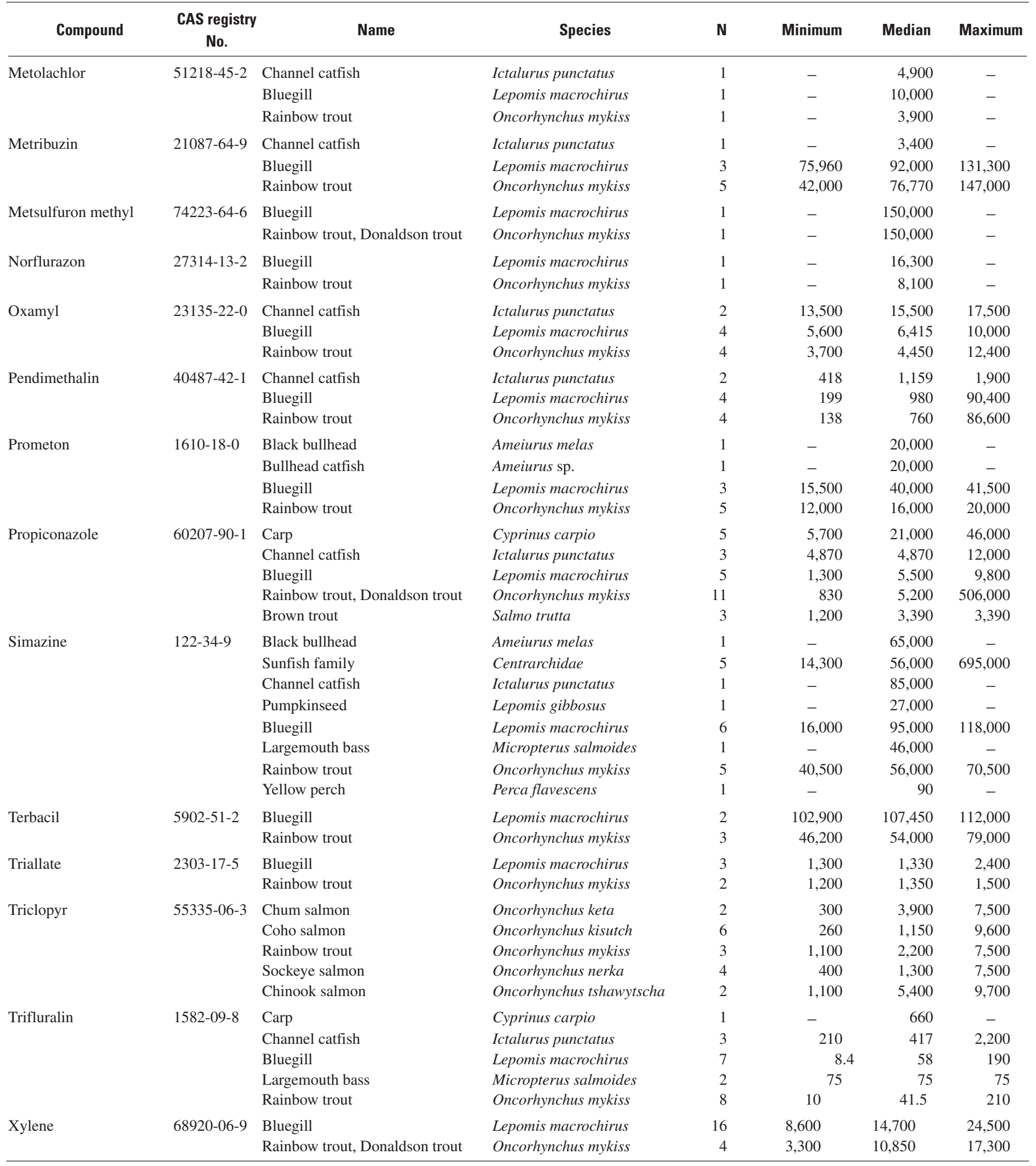



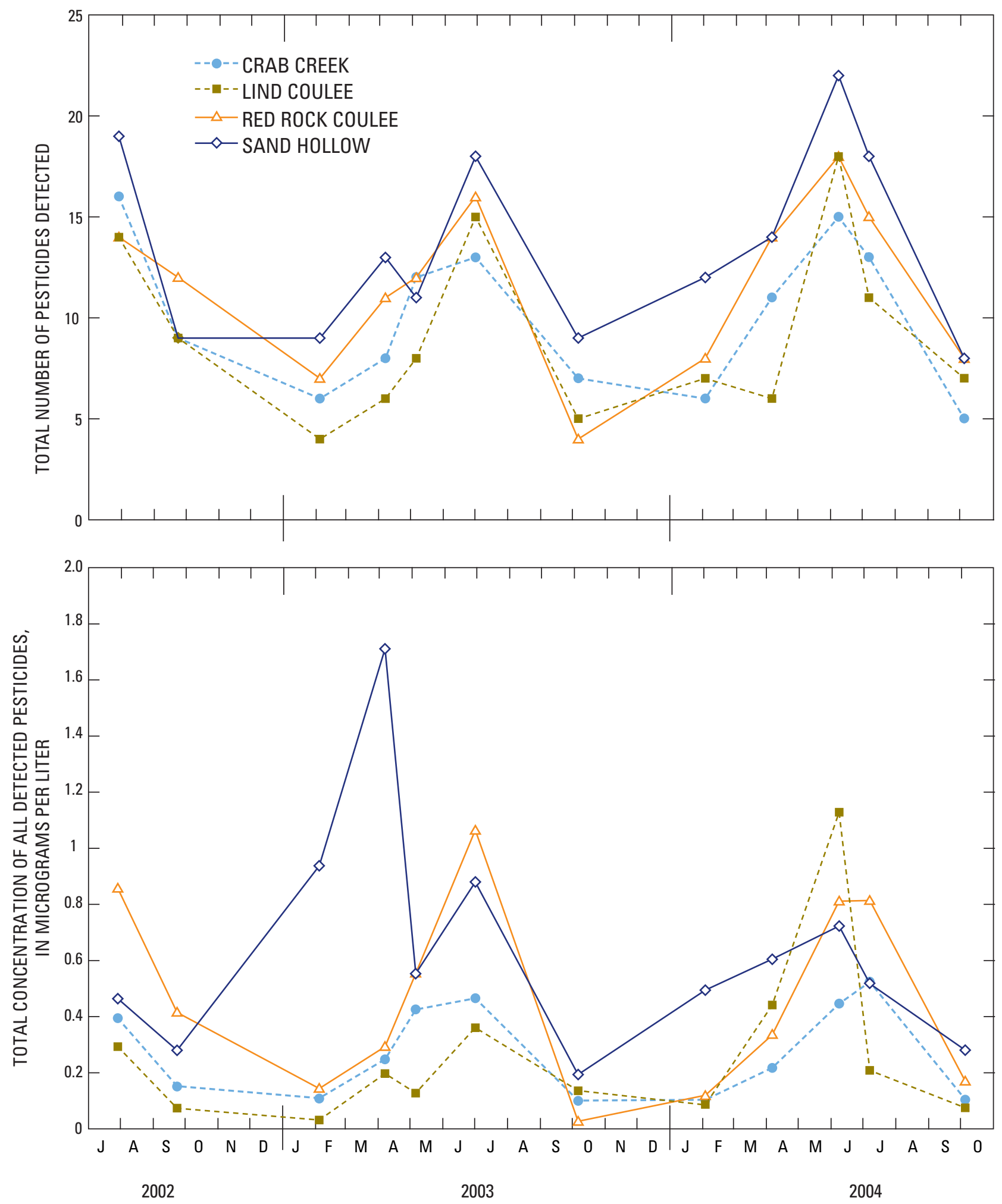

Figure 4. Pesticide concentrations in four irrigation return-flow drainage basins, Columbia Basin Project, Washington, July 2002 to October 2004. 


\section{Relation of Pesticide Use and Pesticides Detected}

The frequency of pesticide detections is related to chemical and physical properties of the specific pesticide, environmental conditions, and amount of pesticide used. Frequency of pesticide detection typically is low in areas of low use and high where pesticide use is high. Seventy to 80 percent of total annual pesticide use in the United States is in agriculture (Aspelin, 1997). Non-agricultural uses may be significant in some areas, however, and include residential pest control, aquatic pest control, rights-of-way applications for pest control, ornamental and turf pest control, and pest control in commercial, industrial, and institutional settings (Larson and others, 1997).

\section{Pesticide-Use Data}

For each pesticide detected in the drainage basins, the total quantity of each pesticide applied to agricultural fields in 2003 was estimated as the sum of annual pesticide applications to each crop type in the drainage basin. For each pesticide applied to a specific crop in a given drainage basin, the total quantity used annually was computed as the product of the rate of pesticide application to that crop in pounds of active ingredient per acre per year, the total acreage of the crop in the drainage basin, and the percentage of that total acreage estimated to be treated with the pesticide. Pesticide application rates and treatment percentages were obtained from the National Agriculture Statistics Service (NASS) where possible (U.S. Department of Agriculture, 2005) and from a 1995 survey conducted in the study area by the National Center for Food and Agricultural Policy (Anderson and Gianessi, 1995) for those crops that are not included in the NASS statistics. Data for total crop acreages were obtained from a geographic information system database of cultivated fields (Patricia Daly, Franklin County Conservation District, written commun., 2004). The crop-acreage database includes only acreages for alfalfa, corn, onions, potatoes, pasture, peas, mint, wheat, and orchards and does not include acreages for minor crops such as carrots; therefore, some pesticides that may be used in the basin were not included in the calculation if they are used specifically on only a few crops not in the database.

In addition to pesticides applied to agricultural lands for control of weeds and pests, herbicides are applied to roads and rights-of-way along irrigation canals, drains, and return flows by local irrigation districts to control terrestrial weed growth (table 10). Herbicide application for non-agricultural weed control ranged from 470 to 10,300 lb during 2003.
Concentrations of only three of the eight herbicides (2,4-D, dicamba, and diuron were analyzed in samples of irrigationreturn flow during this study. Diuron and 2,4-D were among the five most frequently detected pesticides and dicamba was detected in nearly 25 percent of samples collected during this study (table 7).

Pesticide-use data for residential and other nonagricultural uses are more limited than data for agricultural pesticide use (Barbash and Resek, 1996). No studies of non-agricultural pesticide use in the study area are known to exist. However, an estimate of residential use in the study area was computed on the basis of residential sales data collected in King County, Wash. (Phillip Dickey, Washington Toxics Coalition, written commun., 2004). A per-household sales rate was computed on the basis of total housing units in King County (U.S. Census Bureau, 2004), and this rate was multiplied by total housing units in each drainage basin. This method for computing the amount of residential pesticide use assumes that all pesticides purchased in a given year are used that year and that residential usage patterns in the study area are the same as those in King County. Pesticide registration data for the State of Washington are available from Washington State Pest Management (http://wsprs.wsu. edu/Pesticides.html), and the registration status of pesticides analyzed in this study is listed in table 19 (at back of report).

Table 10. Herbicides applied to irrigation canals, roads, and rights of way along irrigation canals, drains, and return flows in the four irrigation return-flow drainage basins, Columbia Basin Project, 2003.

[Abbreviations: CAS, Chemical Abstract Services; None, none applied in 2003; UH, used historically; -, not available]

\begin{tabular}{|c|c|c|}
\hline Herbicide & $\begin{array}{c}\text { Trade or } \\
\text { common name }\end{array}$ & $\begin{array}{l}\text { Amount applied } \\
\text { (pounds) }\end{array}$ \\
\hline $2,4-\mathrm{D}^{1}$ & Weedestroy AM-40 & 10,300 \\
\hline Acrolein & Magnacide $\mathrm{H}$ & UH \\
\hline Copper sulfate & - & $\mathrm{UH}$ \\
\hline Dicamba & Banvel, Vanquish & 510 \\
\hline Diuron & Diuron 4L1VM, Direx & 8,560 \\
\hline Glyphosate $^{2}$ & AquaNeat & 3,350 \\
\hline Imazypyr & Arsenal & UH \\
\hline Metsulfuron methyl & Escort x P & 470 \\
\hline Xylene & - & None \\
\hline
\end{tabular}




\section{Pesticides Applied and Detected in Surface- Water Samples}

Of the 107 pesticides analyzed for in surface-water samples from the four drainage basins, 42 herbicides, insecticides, and fungicides were detected, and 31 of those detected were reported as being applied to the major agricultural crops in the basins (fig. 5). Pesticides that were analyzed for but not detected are listed in table 20 (at back of report).

The general pesticide-usage pattern in each basin varies depending on the acreage of crops grown in that basin. In drainage basins where orchards predominate, the largest applications are insecticides, whereas in basins with larger percentages of field crops the largest application is herbicides. Usage patterns in Crab Creek and Sand Hollow basins are similar: the largest total amounts applied are the insecticides azinphos-methyl, carbaryl, and chlorpyrifos and the herbicide EPTC (fig. 5). In Red Rock Coulee basin, DCPA was the most heavily applied pesticide, followed by the fungicide chlorothalonil, the herbicide EPTC, and the insecticides chlorpyrifos and azinphos-methyl. In Lind Coulee basin, which has a large percentage of dryland agricultural area, the herbicides 2,4-D and EPTC were applied in the largest amount, followed by the fungicide chlorothalonil.

The total amount of pesticides applied in a basin does not correspond directly with the percentage of samples with detections. Some pesticides, such as atrazine, bentazon, and diuron, are applied in small amounts but were detected in a large percentage of samples; others, such as chlorothalonil, are applied in large amounts but were not frequently detected. Other pesticides, such as carbofuran, methyl parathion, and oryzalin, are known to be used on agricultural crops in the study area but were not detected in any of the surface-water samples.

Eleven pesticides that were detected in the drainage basins are available for purchase and use for residential applications (table 11). A nationwide study in the early 1990s showed that total amounts of pesticides sold for agricultural use exceeded those used for non-agricultural use by a factor of three (Aspelin and others, 1992). However, in this study area, the total amount of non-agricultural pesticides applied in these basins was significantly less than amounts applied to major agricultural crops. For example, the highest total non-cropland usage of 2,4-D was 35 pounds applied in Crab Creek and Lind Coulee, whereas agricultural use amounted to greater than 29,000 $\mathrm{lb}$ in that basin. Prometon and triclopyr were the only residential or commercially applied pesticides not used on major agricultural crops; however, they have many commercial uses, such as on landscaping, highway, or power line rights-ofway, so detections can not be linked directly to residential use.
Eight pesticides were detected in the drainage basins, but were not reported as having any major agricultural or residential use (table 12). Most of these were detected only once or twice, except for bromacil and dinoseb. Bromacil is an herbicide detected in samples from all drainage basins and is registered for use along highway right-of-ways, parking lots, and commercial landscaping. The USEPA banned dinoseb use in 1986. However, according to the Washington Agricultural Statistics Service (2005), dinoseb was reported as being used on apples as late as 2001. Possibly, the detection of dinoseb in the Sand Hollow basin indicates current use.

Table 11. Estimated application for residential use of non-agricultural pesticides detected in water samples from the four irrigation return-flow drainage basins, Columbia Basin Project, Washington, July 2002 to October 2004.

[All application values are in pounds per year. <, less than]

\begin{tabular}{lcccc}
\hline & \multicolumn{4}{c}{$\begin{array}{c}\text { Estimated application of non-agricultural pesticides } \\
\text { in irrigation-return flow drainages }\end{array}$} \\
\cline { 2 - 5 } \multicolumn{1}{c}{ Pesticide } & $\begin{array}{c}\text { Crab } \\
\text { Creek }\end{array}$ & $\begin{array}{c}\text { Lind } \\
\text { Coulee }\end{array}$ & $\begin{array}{c}\text { Red Rock } \\
\text { Coulee }\end{array}$ & $\begin{array}{c}\text { Sand } \\
\text { Hollow }\end{array}$ \\
\hline 2,4-D & 35 & 35 & 1.4 & 3.4 \\
Carbaryl & 14 & 14 & .5 & 1.3 \\
Chlorothalonil & 1 & 1.0 & .04 & .1 \\
Chlorpyrifos & .1 & .1 & $<.01$ & .01 \\
Diazinon & 7.8 & 7.9 & .3 & .8 \\
Dicamba & 2.4 & 2.5 & .1 & .2 \\
Malathion & 5.5 & 5.6 & .2 & .5 \\
Pendimethalin & 1.7 & 1.7 & .06 & .2 \\
Prometon & 3.0 & 3.0 & .1 & .3 \\
Triclopyr & 2.1 & 2.1 & .08 & .2 \\
Trifuluralin & 4.1 & 4.1 & .2 & .4 \\
\hline
\end{tabular}

Table 12. Pesticides with no reported residential or major agricultural use detected in water samples from the four irrigation return-flow drainage basins, Columbia Basin Project, Washington, July 2002 to October 2004.

\begin{tabular}{ll}
\hline \multicolumn{1}{c}{ Pesticide } & \multicolumn{1}{c}{ Possible sources } \\
\hline Benomyl & Minor agricultural use \\
Bromacil & Rights-of-way, parking lots, commercial landscaping \\
Clopyralid & Minor agricultural use \\
Dinoseb & Historical use, banned in 1986 \\
Diphenamid & Unknown, not registered for use in Washington \\
Ethalfluralin & Minor agricultural use \\
gamma-HCH & \\
\multicolumn{1}{c}{ (Lindane) } & Seed treatment, head-lice and animal shampoos \\
Linuron & Minor agricultural use \\
\hline
\end{tabular}



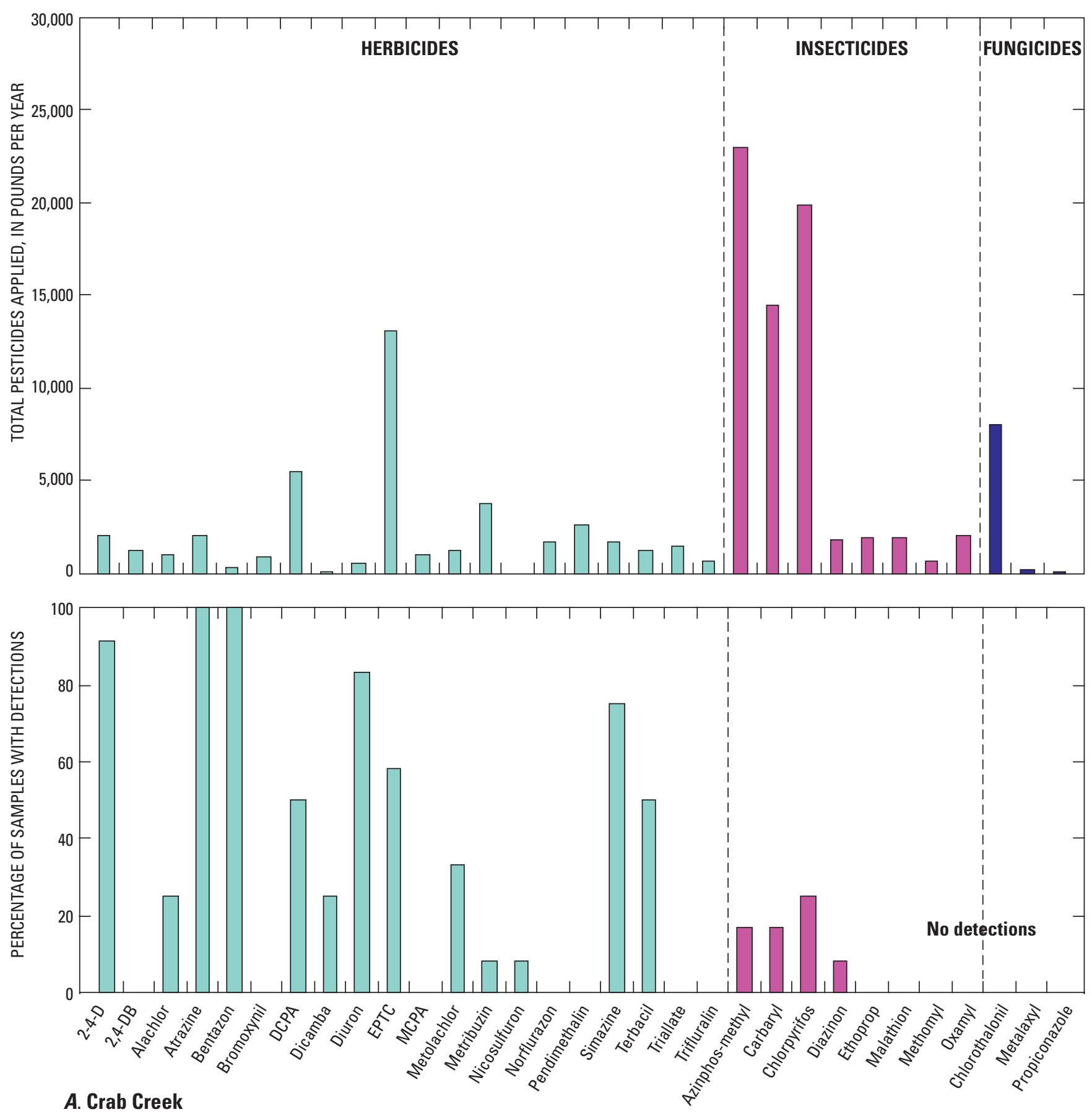

Figure 5. Pesticide-application rates and percentage of surface-water samples with pesticide detections in the four irrigation returnflow drainage basins, Columbia Basin Project, Washington, July 2002 to October 2004. 

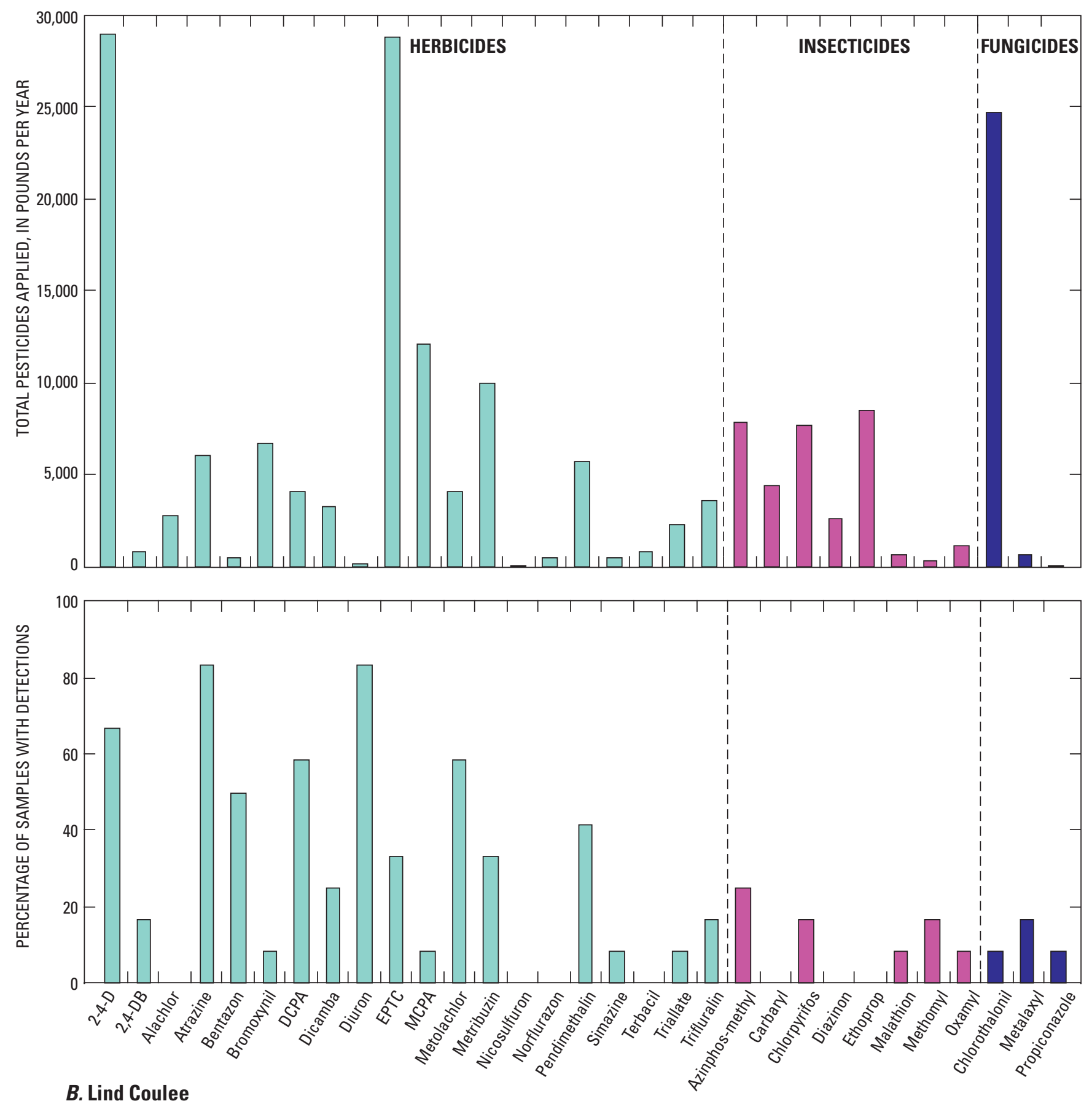

Figure 5. Continued. 

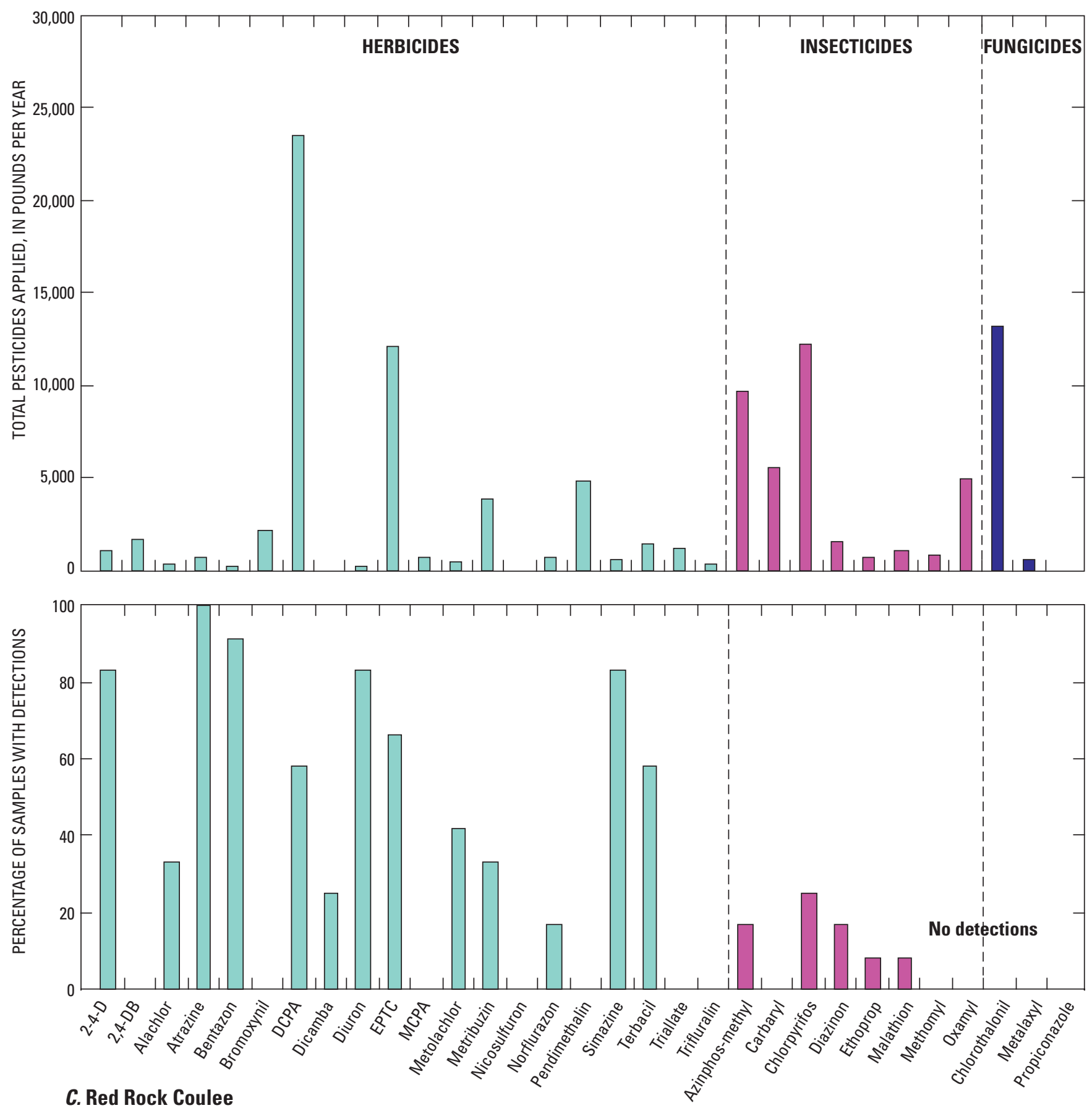

Figure 5. Continued. 

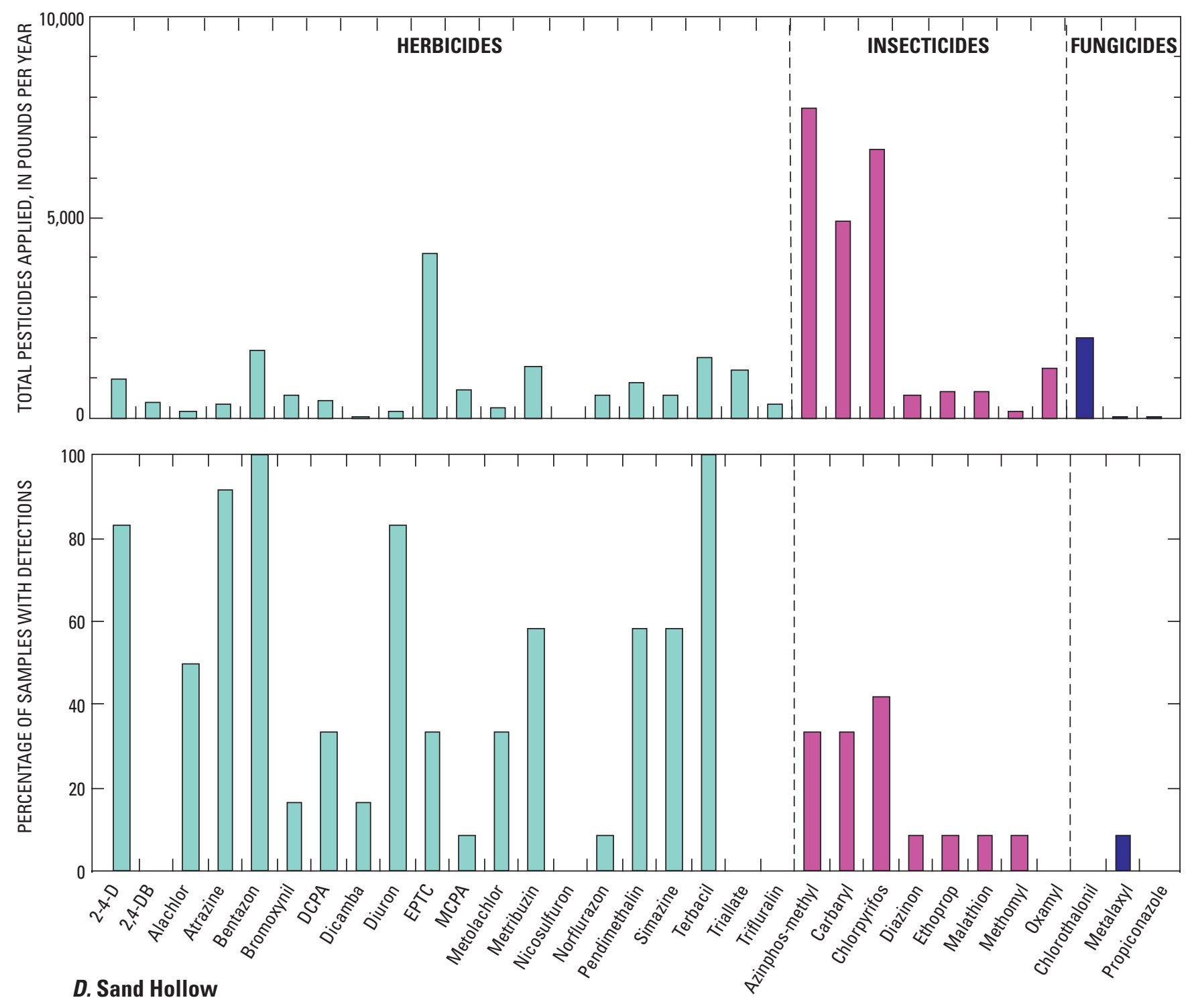

Figure 5. Continued. 


\section{Transport of Pesticides}

\section{Comparison of Pesticide Detections with Historical Data}

Most historical pesticide data for sites in this study were collected during the 1990s by the USGS NAWQA program. Samples also were collected in the mid-1970s in Crab Creek and Lind Coulee basins by the Bureau of Reclamation, and some samples were collected by the Washington State Department of Ecology. Only one previous sample exists for Red Rock Coulee basin, so no comparison was made for that basin.

\section{Comparison with 1970s Data}

Thirteen of the pesticides analyzed for in the 1970s in samples from Crab Creek and Lind Coulee basins also were analyzed for in this study (table 13). Of these pesticides,

Table 13. Detection rates of pesticides analyzed during the 1970 s and from July 2002 to October 2004 in Crab Creek and Lind Coulee irrigation return-flow drainage basins, Columbia Basin Project, Washington.

[Detection rates are number of detections/number of samples analyzed]

\begin{tabular}{|c|c|c|c|c|}
\hline \multirow{3}{*}{ Pesticide } & \multicolumn{4}{|c|}{ Detection rate } \\
\hline & \multicolumn{2}{|c|}{1970 s } & \multicolumn{2}{|c|}{$\begin{array}{c}\text { Current study (July } 2002 \text { to } \\
\text { October 2004) }\end{array}$} \\
\hline & $\begin{array}{l}\text { Crab } \\
\text { Creek }\end{array}$ & $\begin{array}{l}\text { Lind } \\
\text { Coulee }\end{array}$ & $\begin{array}{l}\text { Crab } \\
\text { Creek }\end{array}$ & $\begin{array}{l}\text { Lind } \\
\text { Coulee }\end{array}$ \\
\hline 4,4'-DDE & $2 / 37$ & $2 / 38$ & $0 / 12$ & $0 / 12$ \\
\hline Diazinon & $0 / 37$ & $0 / 38$ & $1 / 12$ & $0 / 12$ \\
\hline Dieldrin & $3 / 42$ & $13 / 38$ & $0 / 12$ & $0 / 12$ \\
\hline Disulfoton & $0 / 37$ & $0 / 38$ & $0 / 12$ & $0 / 12$ \\
\hline EPTC & $0 / 37$ & $0 / 38$ & $7 / 12$ & $4 / 12$ \\
\hline alpha-HCH & $0 / 5$ & $0 / 0$ & $0 / 12$ & $0 / 12$ \\
\hline $\begin{array}{l}\text { gamma-HCH } \\
\text { (Lindane) }\end{array}$ & $4 / 42$ & $0 / 38$ & $0 / 12$ & $0 / 12$ \\
\hline Malathion & $0 / 37$ & $0 / 38$ & $0 / 12$ & $1 / 12$ \\
\hline Methyl parathion & $0 / 37$ & $0 / 38$ & $0 / 12$ & $0 / 12$ \\
\hline Parathion & $0 / 37$ & $0 / 38$ & $0 / 12$ & $0 / 12$ \\
\hline Trifluralin & $0 / 37$ & $0 / 38$ & $0 / 12$ & $2 / 12$ \\
\hline Aldicarb & $0 / 37$ & $0 / 38$ & $0 / 12$ & $0 / 12$ \\
\hline Cycloate & $0 / 37$ & $0 / 38$ & $0 / 12$ & $0 / 12$ \\
\hline
\end{tabular}

4,4'-DDE, dieldrin, and lindane were detected in the 1970s (Greene and others, 1994) and diazinon, EPTC, malathion, and trifluralin were detected during this study. However, given the much lower reporting limits in the current study, the detections of diazinon, EPTC, malathion, and trifluralin do not necessarily represent an increase in detection rate for those compounds. If the detections in the current study were censored to the historical reporting limits, all of them would be reported as "less than" values. However, the lack of detections of 4,4'-DDE, dieldrin, and lindane in the current study represents a decrease in the detection rate of these compounds. Use of dieldrin and DDT (the parent compound of 4,4'-DDE) were banned in 1985 and 1972, respectively, which likely is a cause for the decrease in detection rates since the 1970s. Decreased detection rates can be a combination of a decrease in usage, the smaller number of samples collected during this study, and changes from furrow to sprinkler irrigation methods (Gruber and Munn, 1996; Ebbert and Kim, 1998). Crab Creek Lateral, a small drainage basin in the CBP north of Red Rock Coulee, was sampled 38 times from 1993 to 1997 during the NAWQA program; 8 of the 38 samples contained dieldrin and 5 of the 38 samples contained trace amounts of 4,4-DDE. Because dieldrin and DDT bind strongly to soil particles, the detection of these banned chemicals in water samples is attributed to erosion from agricultural fields (Gruber and Munn, 1996; Ebbert and Kim, 1998). Degradation of the original pesticides into metabolites that were not analyzed during the current study also may be a factor that makes comparison of older data difficult. Analysis of additional pesticide metabolites should be considered for future studies.

\section{Comparison with 1990s Data}

A better comparison than in the 1970 s can be made between data collected during this study and data collected previously by the NAWQA program at Crab Creek, Lind Coulee, and Sand Hollow during the 1990s, because similar methods were used in both studies. All pesticides detected in the 1990s also were analyzed for in this study; however, some pesticides detected in the current study were not analyzed for in the 1990s, so those were excluded from further analysis.

Thirty-six of the pesticide compounds analyzed for in both studies were detected during the 1990s, and 36 were detected during the current study (table 14). Most compounds detected frequently in one study were detected frequently in 
Table 14. Detection rates of pesticides analyzed for during the 1990s and from July 2002 to October 2004 in the Crab Creek, Lind Coulee, and Sand Hollow irrigation return-flow drainage basins, Columbia Basin Project, Washington.

[Period of record for historical samples: Crab Creek, 1994-95; Lind Coulee, 1994-2000; Sand Hollow, 1994-97. Pesticide: CIAT, 2-Chloro-4isopropylamino-6-amino-s-triazine]

\begin{tabular}{|c|c|c|c|c|c|c|}
\hline \multirow[t]{2}{*}{ Pesticide } & \multicolumn{3}{|c|}{$\begin{array}{l}\text { Percentage of samples with } \\
\text { detections during the } 1990 \text { s }\end{array}$} & \multicolumn{3}{|c|}{$\begin{array}{l}\text { Percentage of samples with } \\
\text { detections during the current study } \\
\text { (July } 2002 \text { to October 2004) }\end{array}$} \\
\hline & Crab Creek & Lind Coulee & Sand Hollow & Crab Creek & Lind Coulee & Sand Hollow \\
\hline 2,4-D & 17 & 29 & 40 & 92 & 67 & 83 \\
\hline 2,4-DB & 0 & 0 & 0 & 0 & 17 & 0 \\
\hline 2,6-Diethylaniline & 0 & 0 & 43 & 0 & 0 & 0 \\
\hline Acetochlor & 0 & 4 & 0 & 0 & 0 & 0 \\
\hline Alachlor & 17 & 40 & 100 & 25 & 0 & 50 \\
\hline Atrazine & 100 & 78 & 100 & 100 & 83 & 92 \\
\hline Azinphos-methyl & 0 & 5 & 0 & 17 & 25 & 33 \\
\hline Benfluralin & 0 & 2 & 0 & 0 & 0 & 0 \\
\hline Bentazon & 50 & 0 & 80 & 100 & 50 & 100 \\
\hline Bromacil & 0 & 0 & 0 & 17 & 42 & 67 \\
\hline Bromoxynil & 0 & 0 & 0 & 0 & 8 & 17 \\
\hline Butylate & 0 & 2 & 0 & 0 & 0 & 0 \\
\hline Carbaryl & 0 & 24 & 14 & 17 & 0 & 33 \\
\hline Carbofuran & 0 & 9 & 0 & 0 & 0 & 0 \\
\hline Chlorothalonil & 0 & 0 & 0 & 0 & 8 & 0 \\
\hline Chlorpyrifos & 17 & 29 & 29 & 25 & 17 & 42 \\
\hline CIAT & 67 & 67 & 86 & 100 & 75 & 92 \\
\hline Clopyralid & 0 & 0 & 0 & 8 & 0 & 0 \\
\hline Cyanazine & 17 & 42 & 0 & 0 & 0 & 0 \\
\hline DCPA & 67 & 65 & 86 & 50 & 58 & 33 \\
\hline Diazinon & 0 & 16 & 0 & 8 & 0 & 8 \\
\hline Dicamba & 0 & 0 & 0 & 25 & 25 & 17 \\
\hline Dieldrin & 0 & 4 & 0 & 0 & 0 & 0 \\
\hline Dinoseb & 0 & 0 & 20 & 0 & 0 & 83 \\
\hline Disulfoton & 0 & 2 & 0 & 0 & 0 & 0 \\
\hline Diuron & 17 & 43 & 0 & 83 & 83 & 83 \\
\hline EPTC & 83 & 55 & 86 & 58 & 33 & 33 \\
\hline Ethalfluralin & 0 & 16 & 0 & 0 & 17 & 0 \\
\hline Ethoprophos & 50 & 13 & 29 & 0 & 0 & 8 \\
\hline Fonofos & 0 & 2 & 0 & 0 & 0 & 0 \\
\hline Lindane & 0 & 0 & 0 & 0 & 0 & 8 \\
\hline Linuron & 0 & 5 & 0 & 8 & 17 & 8 \\
\hline Malathion & 0 & 2 & 14 & 0 & 8 & 8 \\
\hline МСРА & 0 & 0 & 0 & 0 & 8 & 8 \\
\hline Metolachlor & 50 & 56 & 71 & 33 & 58 & 33 \\
\hline Metribuzin & 17 & 22 & 71 & 8 & 33 & 58 \\
\hline Napropamide & 0 & 2 & 0 & 0 & 0 & 0 \\
\hline Norflurazon & 0 & 0 & 0 & 0 & 0 & 8 \\
\hline Oxamyl & 0 & 0 & 0 & 0 & 8 & 0 \\
\hline 4,4'-DDE & 0 & 2 & 0 & 0 & 0 & 0 \\
\hline Pendimethalin & 0 & 33 & 0 & 0 & 42 & 58 \\
\hline Prometon & 0 & 0 & 0 & 0 & 0 & 8 \\
\hline Propyzamide & 17 & 0 & 0 & 0 & 0 & 0 \\
\hline Simazine & 83 & 20 & 71 & 75 & 8 & 58 \\
\hline Terbacil & 83 & 22 & 86 & 50 & 0 & 100 \\
\hline Triallate & 0 & 9 & 0 & 0 & 8 & 0 \\
\hline Triclopyr & 0 & 0 & 0 & 0 & 0 & 8 \\
\hline Trifluralin & 0 & 35 & 0 & 0 & 17 & 0 \\
\hline $\begin{array}{l}\text { No. of samples } \\
\text { collected }\end{array}$ & 6 & 55 & 7 & 12 & 12 & 12 \\
\hline
\end{tabular}


the other, with a few exceptions. For example, cyanazine was detected in more than 40 percent of samples collected from Lind Coulee in the 1990s, but was not detected at all in the current study, and bromacil was not detected at any of the sites in the 1990s but was detected in samples from all three sites in the current study. These differences in detections may be due to changes in land use, changes in crop rotations, or just a strategic change of pesticide applications.

Two methods were used to compare historical data with data from the current study to determine if any change in concentrations occurred over time: (1) the Wilcoxon ranksum test for sites with a small number of samples and a large gap between sampling periods, and (2) the seasonal Kendall test for sites with a larger, more continuous sampling record (Helsel and Hirsch, 2002).

The Wilcoxon rank-sum test (Helsel and Hirsch, 2002) was used to compare historical and current pesticide concentrations at Crab Creek and Sand Hollow. A small number of samples (six to seven) were collected from Crab Creek and Sand Hollow during 1994-95 and 1994-97, respectively. One sample from Sand Hollow in 1992 was analyzed for a limited number of pesticides. This sample was not included in the historical comparison because it was unfiltered water rather than filtered water, as were the other samples.

The rank-sum test is a nonparametric test that uses relative ranks of data points to determine if one data set has higher values than another data set. For these tests, if the earlier data set included all lower ranks and the later data set included all higher ranks, the trend would be decreasing. If no trend was present, then the sums of the ranks would be about equal. A trend was considered to be statistically significant if the $p$-value from the rank-sum test was $\leq 0.05$. Figure 6 shows statistically significant differences in pesticide concentrations between the two study periods.

Statistically significant increases in diuron concentrations $(p$-value $=0.048)$ were observed in samples from Crab Creek. Statistically significant decreases were observed in ethoprophos and atrazine concentrations ( $p$-value $=0.012$ and
0.038, respectively), and all other pesticides detected at Crab Creek showed no statistically significant trend. Statistically significant increases in bromacil, diuron, and pendimethalin concentrations were observed in samples from Sand Hollow ( $p$-values of 0.026, 0.007, and 0.019, respectively) and statistically significant decreases in concentration of 2,6-diethylanaline, alachlor, atrazine, DCPA, and EPTC were observed ( $p$-values of $0.02,0.0005,0.001,0.023$, and 0.023 , respectively). Changes in concentration or detection frequency may be due to reductions in pesticide application, changes in agricultural land use, changes in pesticide use and application techniques, changes in managerial practices, environmental changes that may affect pesticide degradation, differences in times of sample collections, differences in sampling techniques, or any combination of these factors. Additional sampling would be needed to determine if these differences are an actual trend over time. Results from the mid-1990s focused mostly on the non-irrigation and early irrigation seasons, whereas the current study was weighted towards collecting samples throughout the irrigation season.

A larger data set exists for Lind Coulee, because samples were collected from 1994 to 2000 for the previous study and from 2002 to 2004 for the current study. Seasonal Kendall trend analysis was used to determine trends over time using the ESTREND program (Schertz and others, 1991). The seasonal Kendall test is a nonparametric test that compares relative ranks of data rather than actual concentration values. Because the data show changes depending on whether it is irrigation season or not, the seasons were defined to be November through March (non-irrigation season) and April through October (irrigation season) and irrigation season data are compared only with irrigation season data and similarly for non-irrigation season data.

No statistically significant trends were determined at Lind Coulee at $p=0.05$. However, simazine and terbacil showed marginally significant decreasing trends with $p$-values of 0.07 and 0.10 , respectively. Almost all detections occurred prior to 1999 (fig. 7). 


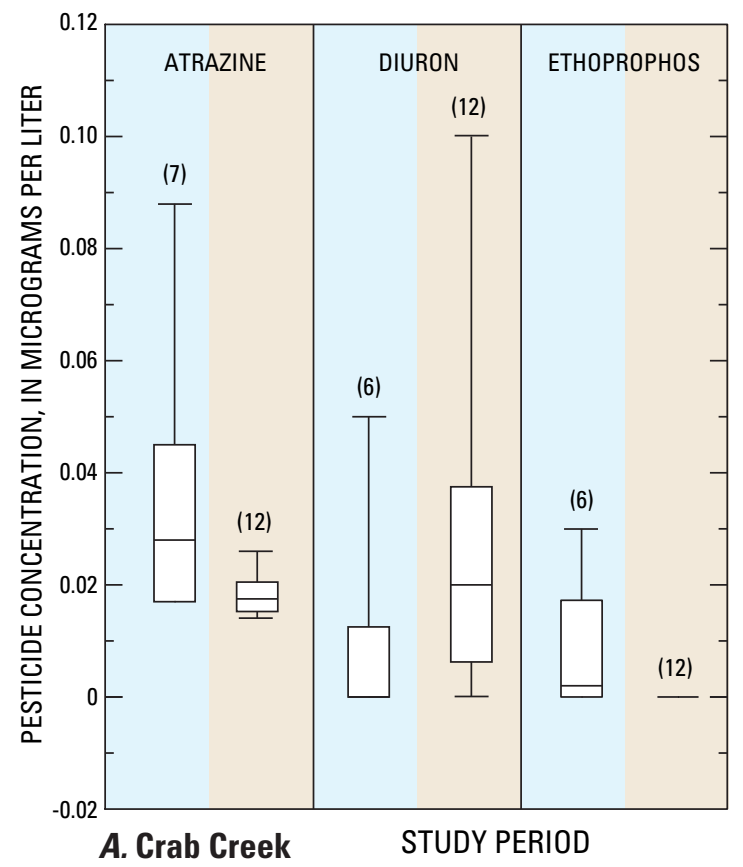

\section{EXPLANATION}

SCHEMATIC BOXPLOT

(12) NUMBER OF DATA POINTS

USED IN CONSTRUCTION OF

- SCHEMATIC PLOT
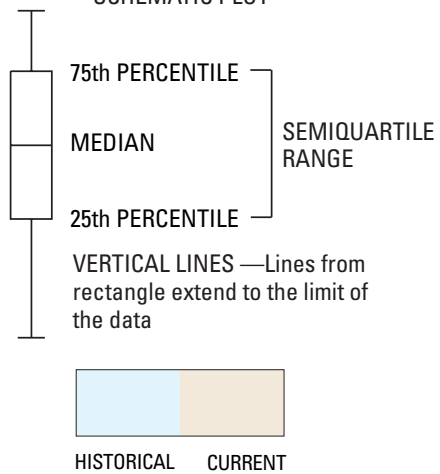

A. Crab Creek STUDY PERIOD

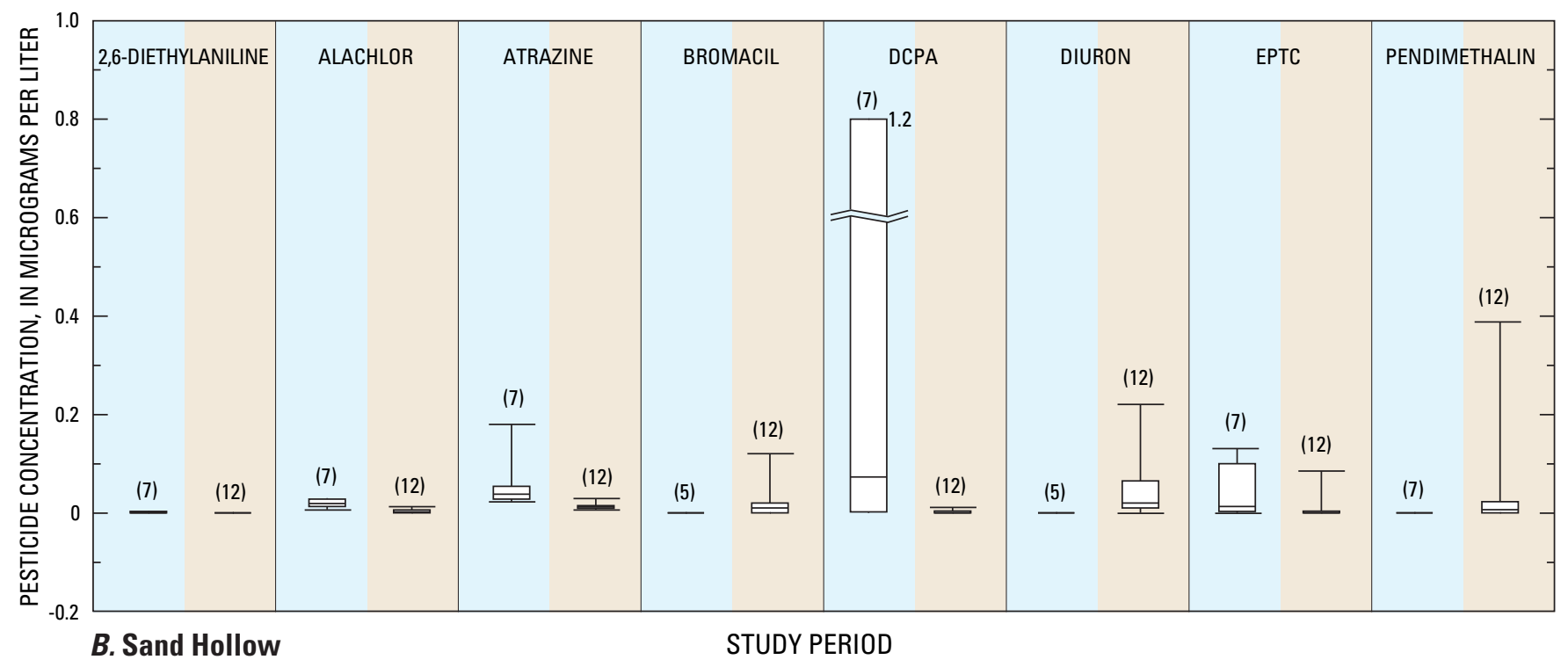

Figure 6 Comparison of historical and current pesticide concentrations in the Crab Creek and Sand Hollow irrigation return-flow drainage basins, Columbia Basin Project, Washington. 

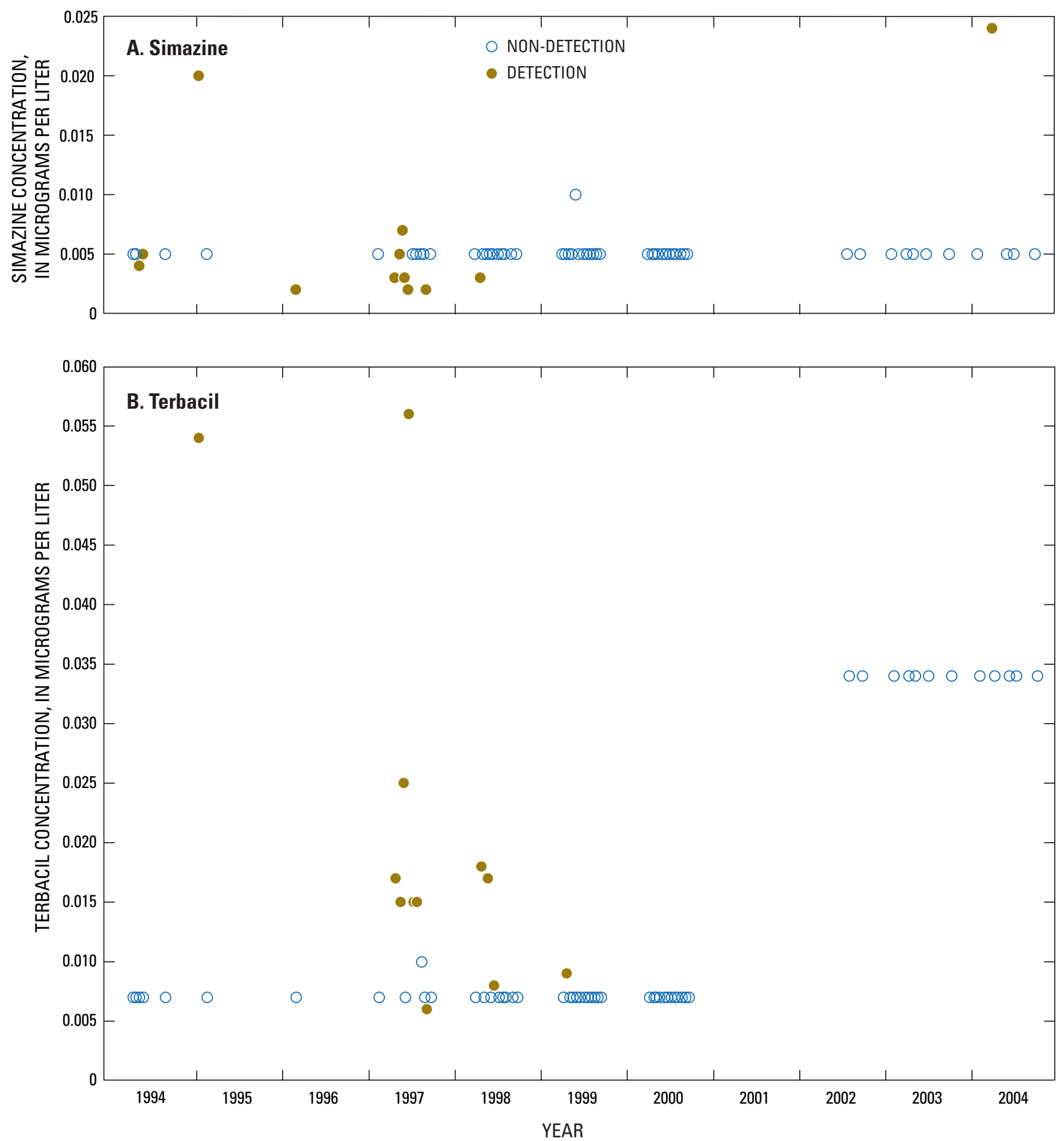

Figure 7. Concentrations of simazine and terbacil in the Lind Coulee irrigation return-flow drainage basin, Columbia Basin Project, Washington, 1994 to 2004. 


\section{Comparison of Pesticide Detections with National NAWQA Data}

Pesticide concentrations detected in this study for the seven most frequently detected herbicides (table 8), as well as dinoseb and the three most frequently detected insecticides, were compared with pesticide concentrations in previous surface-water samples collected throughout the Central Columbia Plateau (Williamson and others, 1998), Yakima River basin (Fuhrer and others, 2004), and national NAWQA study units (fig. 8).

Overall, pesticide data in this study generally agree with those of the Central Columbia Plateau NAWQA study, which included some of the same sites. Pesticides detected during this study tend to decrease on the middle to lower end of the concentration range compared to all streams of the Central Columbia Plateau study area. This difference is partially explained by the NAWQA program goal to sample during all flow stages, including storm samples that likely transport a greater load of pesticides. Maximum concentrations detected in the Central Columbia Plateau study all were higher than those in this study except for terbacil and dinoseb. Although concentrations in this study tended to be lower, the detection rates were higher for all pesticides except simazine. Dinoseb was detected only twice in Central Columbia Plateau streams, one of which was Sand Hollow, where all 10 detections of dinoseb occurred during this study.

In the Yakima River basin, pesticide concentrations in agricultural streams also were similar to those detected in this study (Fuhrer and others, 2004). Pesticide concentration ranges generally overlapped in the mid to lower range for atrazine, simazine, azinphos-methyl, and carbaryl; terbacil and chlorpyrifos concentrations generally were higher in samples collected during this study. Detection rates also were slightly lower in this study than from streams in the Yakima River basin for all pesticides except chloropyrifos. 2,4-D, diuron, dinoseb, and bentazon were not analyzed for in the Yakima River basin, so no comparison was made for those compounds.

In comparing pesticide concentrations from this study with NAWQA data collected nationally, pesticide concentrations in this study generally were in the mid to lower one-half of the range of concentrations, except for terbacil detections during this study, which are in the upper end of the national range (fig. 8). The detection rate was similar for atrazine, CIAT, simazine, carbaryl, and chlorpyrifos, but was substantially higher in this study for terbacil, 2,4-D, bentazon, diuron, azinphos-methyl, and dinoseb. Dinoseb, in particular, stands out, because it was detected in less than 1 percent of all samples nationally but in 15 percent of samples in this study and about 60 percent of samples in the Sand Hollow drainage basin.
Pesticides are applied to agricultural crops and residential lawns and gardens for control of weeds, insects, fungus, and other undesirable factors. Once applied, pesticides are subject to three types of processes, as described by Larsen and others (1997), that control the behavior and fate of pesticides in the environment: (1) transformation processes that change the chemical structure, (2) phase-transfer processes that control pesticide movement between water, biota, sediment, and the atmosphere; and (3) transport processes that move pesticides from the initial point of application to the environment. Major pathways of pesticide transport in this study were irrigationreturn flows, and major transport processes are by direct surface-water runoff from agricultural fields and by groundwater discharge that contains pesticides that have leached into ground water (Jones and Roberts, 1998). Pesticide runoff from right-of-way, commercial, and residential application also is a potential source of pesticide transport.

Streams interact with ground water in all landscapes (Winter and others, 1998). Streams lose water to ground water through the streambed and gain water from inflow of ground water through the streambed. Cessation of irrigation delivery water during non-irrigation seasons changes the relative difference between the altitude of the water table near the streams and the altitude of the surface-water surface, leading to ground-water flow to streams. Williamson and others (1998) showed that many irrigation wasteways and drains in the CBP receive large contributions of ground-water discharge. In the four drainage basins in this study, irrigation water is not delivered from November to March, and in the absence of natural runoff from rainfall, ground water is the predominant source of nitrate in surface-water irrigation-return flow (fig. 9). Fuhrer and others (2004) have shown that groundwater discharges are a major source of surface-water nitrate in irrigated areas of the western United States. Williamson and others (1998) note that, like nitrate, soluble pesticides such as atrazine can leach into ground water of the CBP and later be transported to agricultural irrigation-return flow drainages. Concentrations of atrazine in the study basins do not decrease during the non-irrigation season and actually increase in samples collected from Sand Hollow during the non-irrigation season (fig. 9).

Pesticides that are readily soluble in water, such as herbicides atrazine, bentazon, and diuron (table 15), also can be transported to irrigation-return flows by runoff from agricultural fields, highway or power line rights-of-way, and commercial or residential properties. Pesticide presence usually is related to the timing of pesticide application, pesticide properties, agricultural irrigation practices, and environmental conditions at the time of application (Wagner and others, 1996; Ebbert and Kim, 1998). Transport of pesticides also is dependent on the rate of application, the rate at which pesticides break down in soil and water, and the physical properties of the pesticide that allow it to dissolve and be transported by water (Williamson and others, 1998). 


\section{Herbicides-In Water}

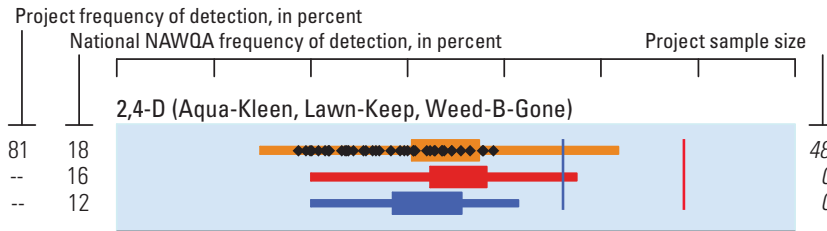

Atrazine (AAtrex, Atrex, Atred)

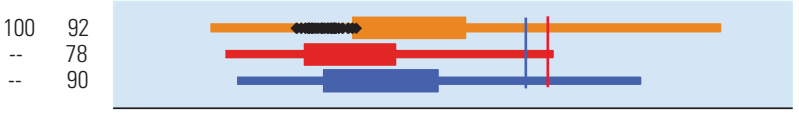

Bentazon (Basagran, Betazone, Bendioxide)

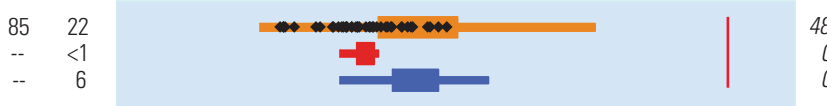

CIAT - Deethylatrazine (Atrazine metabolite, desethylatrazine) ***

$$
92
$$$$
--\quad 59
$$

82
59
78

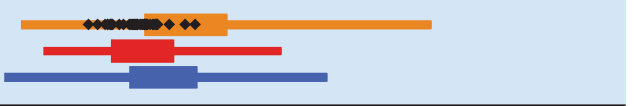

\section{Insecticides-In Water}

Azinphos-methyl (Guthion, Gusathion M) *

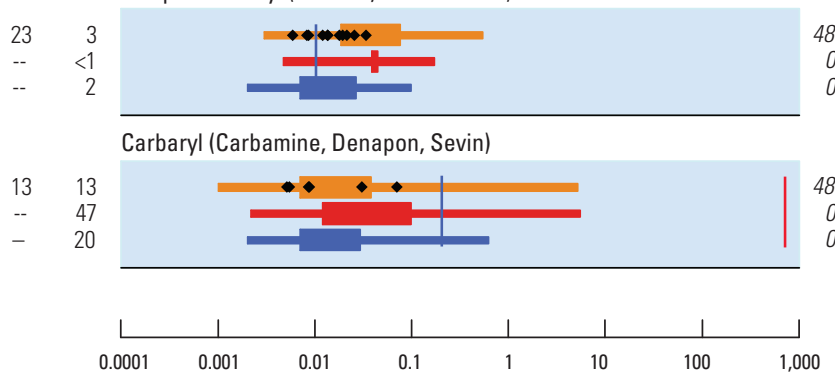

\section{EXPLANATION}

\section{CHEMICALS IN WATER}

Concentrations and detection frequencies, Columbia Basin Project 2002-04

- Detected concentrations in project

9282 Frequencies of detection, in percent. Detection frequencies were not censored at any common reporting limit. The left-hand column is the study-unit frequency and the right-hand column is the national frequency.

$<\quad$ Less than

-- $\quad$ Not measured or sample size less than two

48 Project sample size

National ranges of detected concentrations, by land use, in

51 NAWOA Study Units, 1991-2001—Ranges include only samples in which a chemical was detected

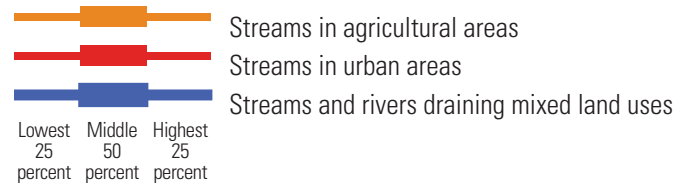

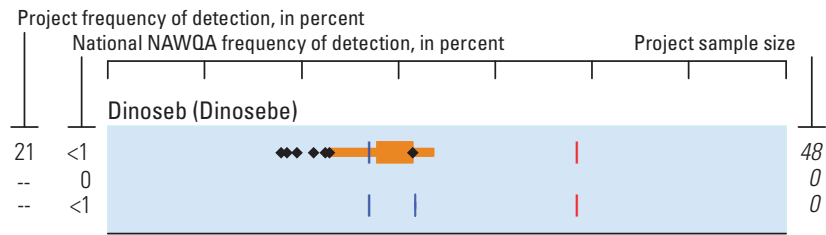

Diuron (Crisuron, Karmex, Direx, Diurex)

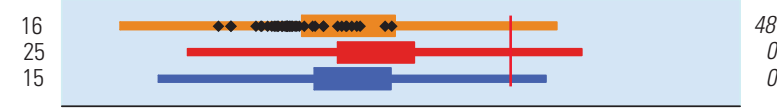

Simazine (Princep, Caliber 90, Gesatop, Simazat)

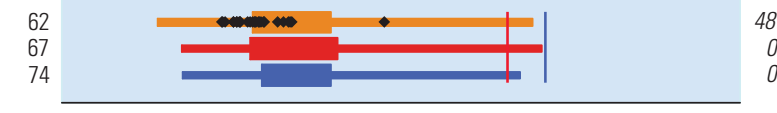

Terbacil (Sinbar)

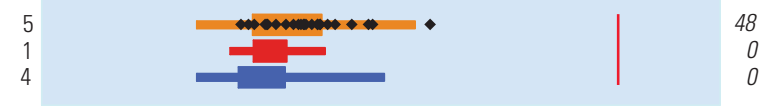

Chlorpyrifos (Brodan, Dursban, Lorsban)
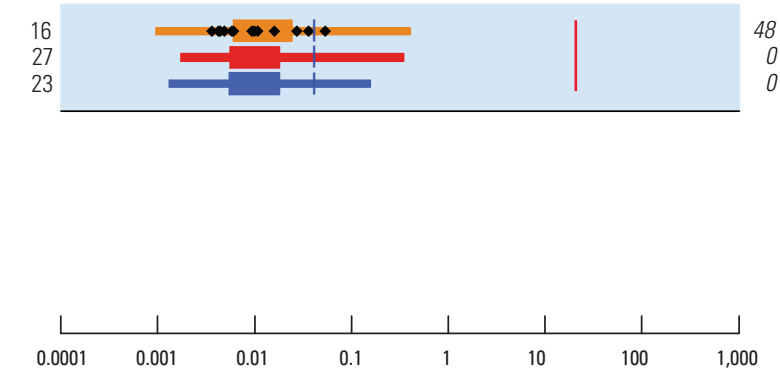

National water-quality benchmarks

National benchmarks include standards and guidelines related to drinking-water quality, criteria for protecting the health of aquatic life. Sources include the U.S. Environmental Protection Agency and the Canadian Council of Ministers of the Environment

I Drinking-water quality (applies to ground water and surface water

I Protection of aquatic life (applies to surface water only)

* No benchmark for drinking-water quality

** No benchmark for protection of aquatic life

Figure 8. Comparison of selected pesticide concentrations in the Columbia Basin Project, Washington, July 2002 to October 2004 with national NAWQA concentrations. 


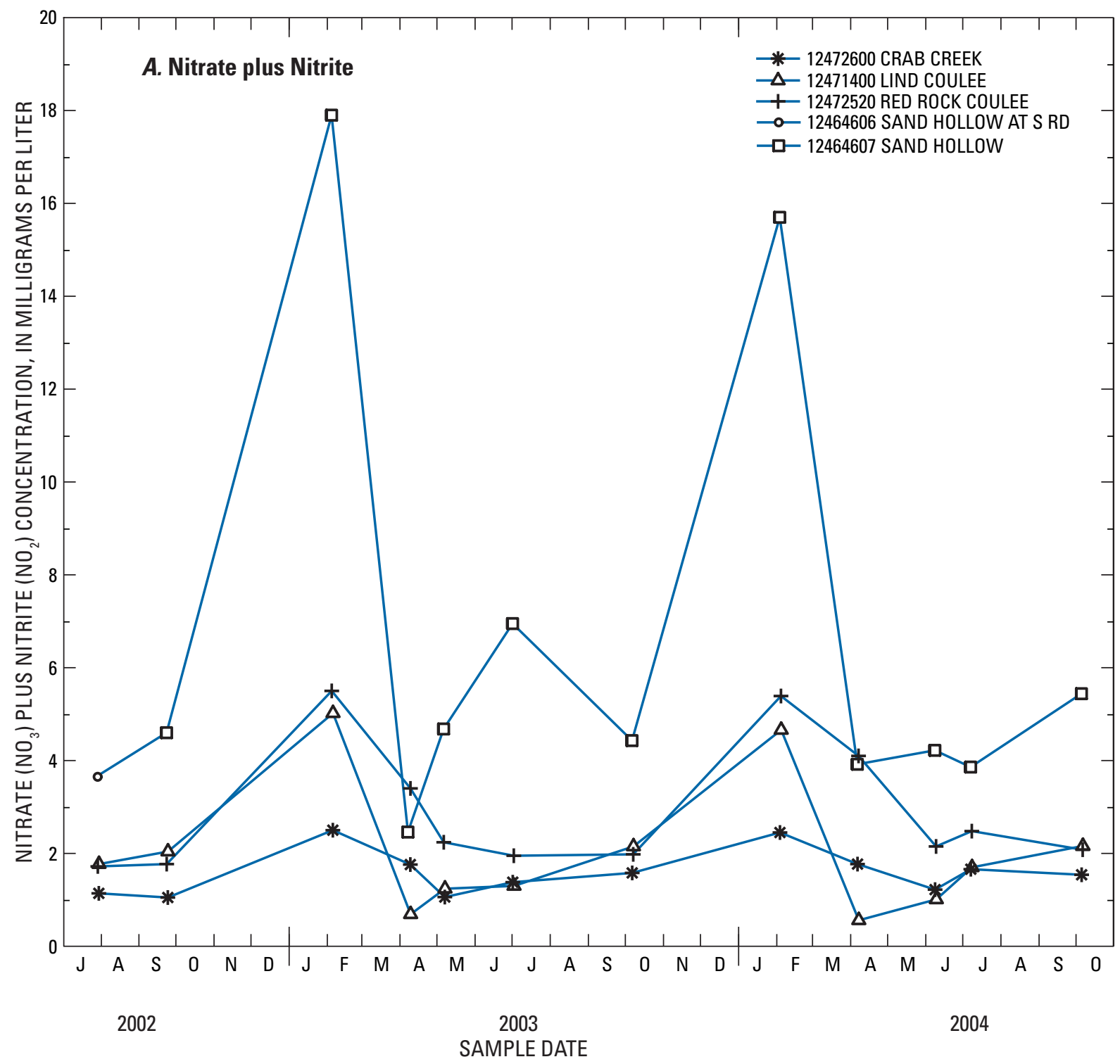

Figure 9. Concentrations of nitrate plus nitrite and atrazine in samples from streamflow-gaging stations in the four irrigation return-flow drainage basins, Columbia Basin Project, Washington, July 2002 to October 2004.

Site 12464606 was sampled only once, in July 2002, and all other samples for Sand Hollow basin were from site 12464607. 


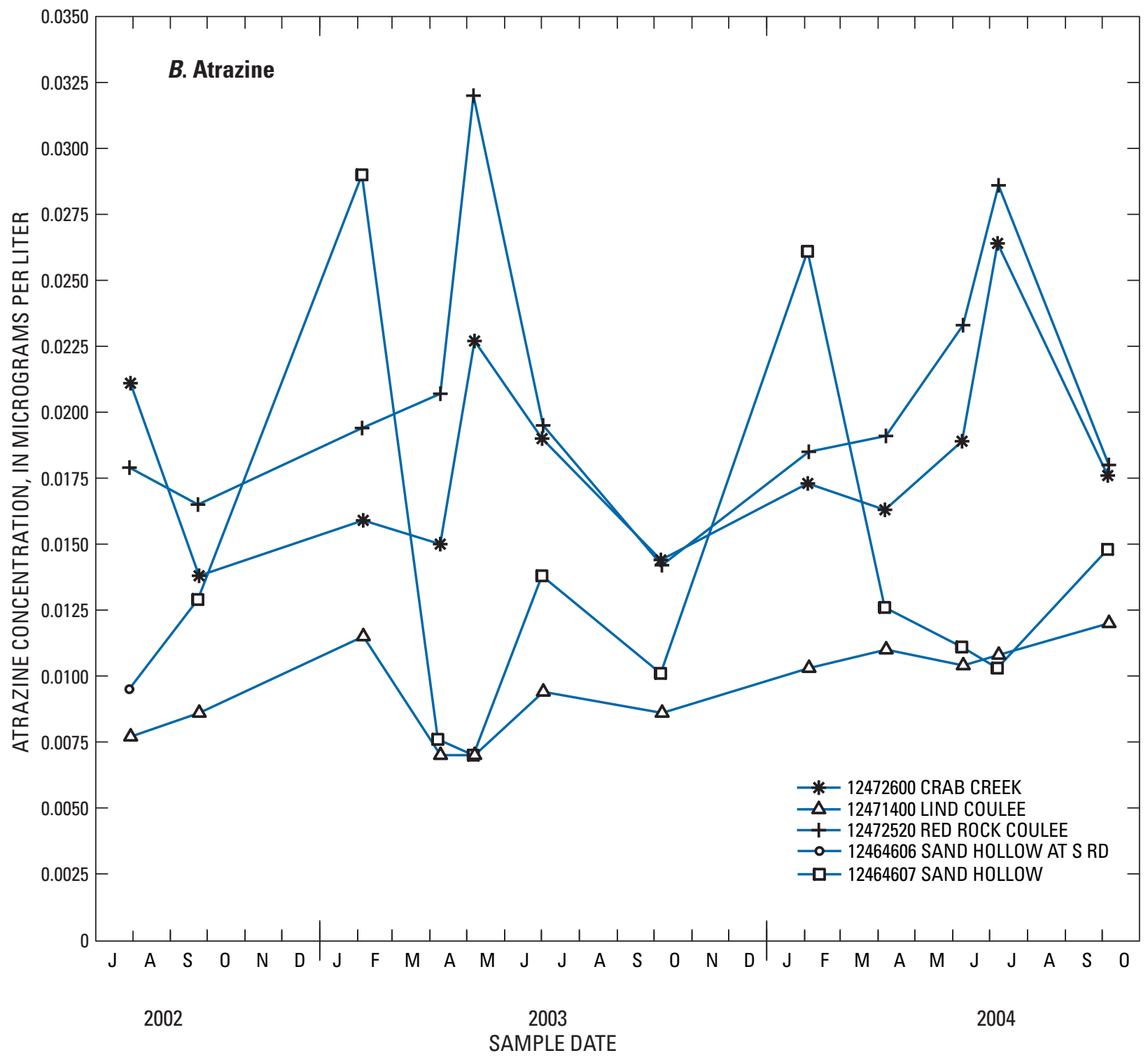

Figure 9. Continued. 
Table 15. Physical and chemical properties of pesticides frequently detected in four irrigation-return flow drainage basins in the Columbia Basin Project, Washington, July 2002 to October 2004.

[Solubility and partition coefficient values are from Mackay and others (1997) unless otherwise indicated. Solubility: is at 25 degrees Celsius. Partition coefficients: $K_{o w}$, octanol-water partition coefficient; $K_{o c}$, adsorption partition coefficient. Type of pesticide: F, fungicide; H, herbicide; I, insecticide. Abbreviations: $\mathrm{mg} / \mathrm{L}$, milligram per liter, $<$, less than;,- , no data]

\begin{tabular}{|c|c|c|c|c|c|c|c|c|c|}
\hline Pesticide & $\begin{array}{c}\text { Type of } \\
\text { pesticide }\end{array}$ & $\begin{array}{c}\text { Solubility } \\
\text { (mg/L) }\end{array}$ & \multicolumn{2}{|c|}{ Partition coefficient } & Pesticide & $\begin{array}{c}\text { Type of } \\
\text { pesticide }\end{array}$ & $\begin{array}{c}\text { Solubility } \\
\text { (mg/L) }\end{array}$ & \multicolumn{2}{|c|}{ Partition coefficient } \\
\hline Atrazine $^{1}$ & $\mathrm{H}$ & 30 & 2.75 & 2.00 & Diazinon & I & 60 & 3.3 & 2.76 \\
\hline Diuron & $\mathrm{H}$ & 40 & 2.78 & 2.6 & Bromoxynil & $\mathrm{H}$ & 130 & $<2.0$ & - \\
\hline $2,4-\mathrm{D}$ & $\mathrm{H}$ & 400 & 2.81 & $1.68-2.73$ & Malathion & I & 145 & 2.8 & 3.26 \\
\hline 2,4-D methyl ester & $\mathrm{H}$ & 100 & - & 2.0 & Metalaxyl & $\mathrm{F}$ & 8,400 & 1.75 & 1.7 \\
\hline Terbacil $^{1}$ & $\mathrm{H}$ & 710 & 1.89 & 1.74 & Norflurazon $^{3}$ & $\mathrm{H}$ & 34 & & 2.79 \\
\hline $\mathrm{DCPA}^{3}$ & $\mathrm{H}$ & .5 & - & - & Trifluralin & $\mathrm{H}$ & ${ }^{4} .5$ & 5.34 & 4.14 \\
\hline EPTC & $\mathrm{H}$ & 370 & 3.2 & 2.3 & $2,4-\mathrm{DB}$ & $\mathrm{H}$ & 46 & 3.53 & 2.64 \\
\hline Bromacil & $\mathrm{H}$ & 815 & 2.11 & 1.86 & Ethalfluralin & & - & - & ${ }^{3} 1.69$ \\
\hline Metolachlor & $\mathrm{H}$ & 430 & 3.13 & 2.26 & Ethoprophos & I & 750 & 3.59 & 1.85 \\
\hline Metribuzin $^{2}$ & $\mathrm{H}$ & 1,050 & 1.60 & 1.79 & MCPA & $\mathrm{H}$ & 1,605 & ${ }^{4} 2.69$ & $2.03-2.07$ \\
\hline Dicamba & $\mathrm{H}$ & 4,500 & 2.21 & $.34,-.4$ & Nicosulfuron $^{3}$ & $\mathrm{H}$ & 18,486 & 1.56 & - \\
\hline Dinoseb & $\mathrm{H}$ & 50 & 3.56 & 2.85 & Oxamyl & $\mathrm{H}$ & 282,000 & -.47 & 1.4 \\
\hline Carbaryl $^{1}$ & I & 120 & 2.36 & 2.36 & Propiconazole & $\mathrm{F}$ & 110 & 3.72 & 2.82 \\
\hline Linuron 1 & $\mathrm{H}$ & 75 & 3.0 & 2.91 & Triallate & $\mathrm{H}$ & 4 & 4.29 & 3.38 \\
\hline Benomyl & $\mathrm{F}$ & ${ }^{4} 2.0$ & 2.3 & 3.28 & Triclopyr & $\mathrm{H}$ & 440 & .42 & $1.30-2.89$ \\
\hline
\end{tabular}

\footnotetext{
${ }^{1}$ Analyzed by gas chromatography/mass spectrometry (GC/MS) and by high-performance liquid chromatography/mass spectrometry (HPLC/MS).

${ }^{2}$ Solubility and partition coefficients are from the Extension Toxicology Network (EXTOXNET), accessed August 22, 2005, at http://extoxnet.orst.edu/.

${ }^{3}$ Solubility and partition coefficients are from the Pesticides Action Network (PAN) pesticides database, accessed August 22, 2005, at http://www. pesticideinfo.org/Index.html.

${ }^{4}$ Reported values vary considerably. Selected value represents best judgment by Mackay and others (1997) and may be subject to a large error.
}

The herbicides atrazine, bentazon, diuron, and 2,4-D were detected in more than one-half of samples collected at all four sites. Water solubility of these herbicides ranges from 30 to $500 \mathrm{mg} / \mathrm{L}$, and the adsorption coefficients $\left(\log K_{o c}\right)$, which indicate a chemical's affinity to partition to soil particles, is relatively low. These physical and chemical characteristics lead to a low affinity for adhering to sediment and to a high potential for the compounds to dissolve and be transported in water.

The insecticides chlorpyrifos and azinphos-methyl each were detected in about one-fourth of samples collected during this study and were detected in all four irrigation returnflow basins, although most detections were in Sand Hollow drainage basin. The insecticide carbaryl was detected in 6 of
48 samples, primarily in samples from Sand Hollow drainage basin. Both azinphos-methyl and carbaryl are readily soluble in water, with 30 and $120 \mathrm{mg} / \mathrm{L}$ solubility, respectively. The relatively low adsorption coefficient means that these insecticides are likely to dissolve and be transported in water. Conversely, chlorpyrifos has a low solubility in water $(0.73 \mathrm{mg} / \mathrm{L})$ and a relatively large adsorption coefficient, so is more likely to bind to soil particles. Therefore, transport of chlorpyrifos is by means of soil erosion into the irrigationreturn flows. Because chlorpyrifos recently was listed by USEPA as a Restricted Use Product (U.S. Environmental Protection Agency, 2003), expectations are that detections of this pesticide should decrease over time. 


\section{Summary}

The U.S. Geological Survey, in cooperation with the Bureau of Reclamation, analyzed water-quality samples from sites in four irrigation-return flow drainage basins in the Columbia Basin Project (CBP) from July 2002 to October 2004 to determine the occurrence, distribution, and transport of pesticides, in response to a recommendation by the National Marine Fisheries Service to monitor water quality in surface-water return flows in the CBP. Ten samples were collected in the Crab Creek, Sand Hollow, Red Rock Coulee, and Lind Coulee drainage basins throughout the irrigation season (generally April through October) and two samples were collected during the non-irrigation season. Samples were analyzed for water temperature, $\mathrm{pH}$, specific conductance, dissolved oxygen, trace elements, major ions, and nutrients, and a suite of 107 pesticides and pesticide metabolites (pesticide transformation products). Measured pesticide concentrations were compared with drinking-water standards and aquatic-life benchmarks, and the presence of pesticides in samples from the irrigation-return flows was compared with historical data and related to current pesticide use, land use, and other environmental factors.

The four drainage basins vary in size from 19 to 710 square miles and the percentage of agricultural cropland ranges from about 35 percent in Crab Creek basin to 75 percent in Lind Coulee basin. More than 95 percent of the cropland in Red Rock Coulee, Crab Creek, and Sand Hollow basins is irrigated, whereas only 30 percent of the cropland in Lind Coulee is irrigated. Estimates of agricultural crop acreage from 2003 were used to describe agricultural land use during the current study. The largest percentage of agricultural crop acreage in Red Rock Coulee, Sand Hollow, and Crab Creek basins was alfalfa. The second largest percentage of cropland in Crab Creek and Sand Hollow basins and third largest in Red Rock Coulee basin was orchards. During 2003, onions were the second largest percentage of crop acreage in Red Rock Coulee basin. Lind Coulee basin has the smallest percentage of irrigated cropland, and about one-third of the crop acreage in dryland wheat and another one-third in fallow cropland. Nearly one-third of the remaining acreage was planted in irrigated wheat, alfalfa, potatoes, corn, and peas.

Although State of Washington water-temperature standards specify that water-temperature criteria be measured by the 7-day average of daily maximum temperatures, this was beyond the scope of this study, so temperatures measured during this study are only an indication of instantaneous temperatures at the time of sampling. Water temperature in 18 samples was greater than the State of Washington criterion of 16 degrees Celsius for salmon and trout spawning, core rearing, and migration: 7 from Red Rock Coulee, 5 from Crab Creek, 4 from Lind Coulee, and 2 from Sand Hollow. In 11 of these 18 instances, temperature also was greater than the criterion of 17.5 degrees Celsius for salmon and trout spawning, non-core rearing, and migration. State of
Washington aquatic-life dissolved-oxygen criteria are listed as 1-day minimum, and the criterion of 9.5 milligrams per liter for salmon and trout spawning, core rearing, and migration was exceeded eight times from June to early October during this study at three sites: two times at Sand Hollow, three times at Red Rock Coulee, and three times at Crab Creek. State of Washington aquatic-life criterion for $\mathrm{pH}$ of 8.5 for fresh water was exceeded 12 times: 6 at Red Rock Coulee, 3 at Sand Hollow, 2 at Lind Coulee and 1 at Crab Creek. Concentrations of nitrate plus nitrite in two samples collected from Sand Hollow during the non-irrigation season exceeded U.S. Environmental Protection Agency Maximum Contaminant Level for drinking water.

Forty-two pesticides and five metabolites were detected in samples from the four irrigation-return flow drainage basins: 37 in Sand Hollow, 33 in Lind Coulee, 30 in Red Rock Coulee, and 28 in Crab Creek. Herbicides were the most frequently detected pesticides, followed by insecticides, metabolites, and fungicides. Atrazine, bentazon, diuron, and 2,4-D were the most frequently detected herbicides and chlorpyrifos and azinphos-methyl were the most frequently detected insecticides.

Concentrations of three insecticides and one herbicide exceeded U.S. Environmental Protection Agency or Canadian freshwater aquatic-life benchmarks. Concentrations of the insecticide azinphos-methyl exceeded the aquaticlife benchmark at least once at each of the four sites. Concentrations in samples from Sand Hollow also exceeded the aquatic-life benchmark for chlorpyrifos, lindane, and dinoseb. Water-quality aquatic-life benchmarks generally were exceeded in June and July, during the middle of the irrigation season, except the criterion for dinoseb, which was exceeded in one sample during the non-irrigation season in February 2003.

Pesticide application rates and treatment percentages from the National Agriculture Statistics Service and from a 1995 survey conducted in the study unit by the National Center for Food and Agricultural Policy and total crop acreage in the drainage basins were used to estimate the total quantity of each pesticide applied to agricultural fields in 2003. Thirtyone of the 42 herbicides, insecticides, and fungicides detected in surface-water samples were applied to the major agricultural crops in the drainage basins, and 11 of the detected pesticides are sold for residential application. Eight pesticides that were not reported as used for agricultural or residential purposes were detected in the surface-water samples. The overall pattern of pesticide use depends on which crops are grown in each basin. In drainage basins with predominantly more orchards, greater amounts of insecticides are applied, whereas in basins with larger percentages of field crops, more herbicides are applied. Similar usage patterns were in Crab Creek and Sand Hollow basins: the most heavily applied insecticides were azinphos-methyl, carbaryl, and chlorpyrifos and the most heavily applied herbicide was EPTC. DCPA was the most heavily applied herbicide in Red Rock Coulee basin, 
followed by the fungicide chlorothalonil, the herbicide EPTC, and the insecticides chlorpyrifos and azinphos-methyl. In Lind Coulee, which has a large percentage of dryland agricultural area, the most heavily applied pesticides were the herbicides 2,4-D and EPTC, followed by the fungicide chlorothalonil. The total amount of non-agricultural pesticides applied by residential homeowners and irrigation districts was negligible compared to total amounts applied to agricultural crops.

A statistical comparison of pesticide concentrations from this study with those in surface-water samples collected in the mid-1990s at Crab Creek and Sand Hollow showed a statistically significant increase in concentrations of diuron and a statistically significant decrease in concentrations of ethoprophos and atrazine in Crab Creek. At Sand Hollow, there were statistically significant increases in concentrations of bromacil, diuron, and pendimethalin and statistically significant decreases in concentrations of 2,6-diethylanaline, alachlor, atrazine, DCPA, and EPTC. A seasonal Kendall trend test on data from Lind Coulee showed no statistically significant trends for any pesticide for 1994 through 2004.

A comparison of pesticide concentrations detected in this study with those detected in previous U.S. Geological Survey National Water-Quality Assessment studies of the Central Columbia Plateau, the Yakima River basin, and national agricultural studies indicated that concentrations in this study generally were in the middle to lower end of the concentration spectrum for the most frequently detected herbicides and insecticides, but that the overall detection rate was at the high end.

\section{References Cited}

American Public Health Association, American Water Works Association, and Water Environment Federation, 1998, Standard methods for the examination of water and wastewater (20 th ed.): Washington, D.C., American Public Health Association, variously paginated.

Anderson, J.E., and Gianessi, L.P., 1995, Pesticide use in the Central Columbia Plateau: Washington, D.C., National Center for Food and Agricultural Policy, variously paginated.

Aspelin, A.L., 1997, Pesticides industry sales and usage, 1994 and 1995 market estimates: U.S. Environmental Protection Agency, Office of Pesticide Programs, Biological and Economic Analysis Division, Economic Analysis Branch Report 733-R-97-002, 35 p.

Aspelin, A.L., Grube, A.H., and Torla, R., 1992, Pesticides industry sales and usage; 1990 and 1991 market estimates: U.S. Environmental Protection Agency, Office of Pesticide Programs, Biological and Economic Analysis Division, Economic Analysis Branch Report 733-K-92-001, 37 p.
Barbash, J.E., and Resek, E.A., 1996, Pesticides in ground water: Distribution, trends, and governing factors: Volume 2 of the series-Pesticides in the Hydrologic System: Chelsea, Michigan, Ann Arbor Press, 590 p.

Bureau of Reclamation, 1982, Columbia Basin Project water quality: Bureau of Reclamation, Pacific Northwest Region, Boise, Idaho, variously paginated.

Canadian Council of Ministers of the Environment, 2003, Summary of existing Canadian environmental quality guidelines, summary table, December 2003: Canadian Council of Ministers of the Environment, $12 \mathrm{p}$.

Canadian Council of Resource and Environment Ministers, 1997, Canadian water quality guidelines (rev. ed.): Ottawa, Ontario, Task Force on Water Quality Guidelines, Canadian Council of Resource and Environment Ministers, loose-leaf (originally published 1987), 23 appendixes.

Drost, B.W., Whiteman, K.J., and Gonthier, J.B., 1990, Geologic framework of the Columbia Plateau Aquifer System, Washington, Oregon, and Idaho: U.S. Geological Survey Water-Resources Investigations Report 87-4238, 10 p., 10 pls.

Ebbert, J.C., and Kim, M.H., 1998, Relation between irrigation method, sediment yields, and losses of pesticides and nitrogen: Journal of Environmental Quality, v. 27, no. 2, p. 372-380., abstract accessed August 22, 2005, at URL: http://wa.water.usgs.gov/pubs/ja/JEQ journal.htm. Edwards, T.K., and Glysson, G.D., 1999, Field methods for measurement of fluvial sediment: U.S. Geological Survey Techniques of Water-Resources Investigations, book 3, chap. C2, 89 p., accessed July 22, 2005, at URL: http:// pubs.water.usgs.gov/TWRI3C2/.

Faires, L.M., 1993, Methods of analysis by the U.S. Geological Survey National Water Quality LaboratoryDetermination of metals in water by inductively coupled plasma-mass spectrometry: U.S. Geological Survey Open-File Report 92-634, 28 p.

Fishman, M.J., 1993, Methods of analysis by the U.S. Geological Survey National Water Quality LaboratoryDetermination of inorganic and organic constituents in water and fluvial sediments: U.S. Geological Survey Open-File Report 93-125, 217 p.

Fishman, M.J., and Friedman, L.C., 1989, Methods for determination of inorganic substances in water and fluvial sediments: U.S. Geological Survey Techniques of Water-Resources Investigations, book 5, chap. A1, 545 p., accessed July 14, 2005, at URL: http://pubs.water.usgs. gov/TWRI5A1/.

Fuhrer, G.J., Morace, J.L., Johnson, H.M., Rinella, J.F., Ebbert, J.C., Embrey, S.S., Waite, I.R., Carpenter, K.D., Wise, D.R., and Hughes, C.A., 2004, Water quality in the Yakima River Basin, Washington, 1999-2000: U.S. Geological Survey Circular 1237, 34 p., accessed August 24, 2005, at URL: http://pubs.water.usgs.gov/circ1237. 
Furlong, E.T., Anderson, B.D., Werner, S.L., Soliven, P.P., Coffey, L.J., and Burkhardt, M.R., 2001, Methods of analysis by the U.S. Geological Survey National Water Quality Laboratory-Determination of pesticides in water by graphitized carbon-based solid-phase extraction and high-performance liquid chromatography/mass spectrometry: U.S. Geological Survey Water-Resources Investigations Report 01-4134, 73 p., accessed July 14, 2005, at URL: http://nwql.usgs.gov/Public/pubs/WRIR014134.html.

Gianessi, L.P., and Puffer, C.A., 1991, Herbicide use in the United States: Washington, D.C., Resources for the Future, Inc., Quality of the Environment Division, 128 p.

Gianessi, L.P., and Puffer, C.A., 1992a, Insecticide use in U.S. crop production: Washington, D.C., Resources for the Future, Inc., Quality of the Environment Division, variously paginated.

Gianessi, L.P., and Puffer, C.A., 1992b, Fungicide use in U.S. crop production: Washington, D.C., Resources for the Future, Inc., Quality of the Environment Division, variously paginated.

Gilliom, R.J., Alley, W.M., and Gurtz, M.E., 1995, Design of the National Water-Quality Assessment ProgramOccurrence and distribution of water-quality conditions: U.S. Geological Survey Circular 1112, 33 p.

Green, K.E., Ebbert, J.C., and Munn, M.D., 1994 [1996], Nutrients, suspended sediment, and pesticides in streams and irrigation systems in the Central Columbia Plateau in Washington and Idaho, 1959-1991: U.S. Geological Survey Water-Resources Investigations Report 94-4215, 125 p., accessed August 25, 2005, at URL: http://pubs.er.usgs. gov/pubs/wri/wri944215.

Gruber, S.J., and Munn, M.D., 1996, Organochlorine pesticides and PCBs in aquatic ecosystems of the central Columbia Plateau: U.S. Geological Survey Fact Sheet FS170-96, 4 p., accessed August 23, 2005, at URL: http:// wa.water.usgs.gov/pubs/fs/fs 170-96/.

Hansen, A.J., Jr., Vaccaro, J.J., and Bauer, H.H., 1994, Ground-water flow simulation of the Columbia Plateau regional aquifer system, Washington, Oregon, and Idaho: U.S. Geological Survey Water-Resources Investigations Report 91-4187, 81 p., accessed August 11, 2005, at URL: http://pubs.er.usgs.gov/pubs/wri/wri914187.

Helsel, D.R., and Hirsch, R.M., 2002, Statistical methods in water resources: U.S. Geological Survey Techniques of Water-Resources Investigations, book 4, chap. A3, Hydrologic Analysis and Interpretation, 510 p., accessed August 12, 2005, at URL: http://pubs.water.usgs.gov/ twri4a3/.

Hem, J.D., 1985, Study and interpretation of the chemical characteristics of natural water: U.S. Geological Survey Water-Supply Paper 2254, 263 p., 2 pls.
International Joint Commission United States and Canada, 1978, Great Lakes Water Quality Agreement of 1978, as amended by Protocol signed November 18, 1987, Annex I-Specific objectives: International Joint Commission United States and Canada. Accessed May 31, 2005, at URL: http://www.epa.gov/glnpo/glwqa/1978/annex.html.

Jones, J.L., and Roberts, L.M., 1998, Shallow ground-water quality beneath row crops and orchard in the Columbia Basin Irrigation Project area, Washington: U.S. Geological Survey Water-Resources Investigations Report 97-4238, 29 p., accessed August 15, 2005, at URL: http://pubs.er.usgs. gov/pubs/wri/wri974238.

Larson, S.J., Capel, P.D., and Majewski, M.S, 1997, Pesticides in surface waters: Distribution, trends, and governing factors: Volume 3 of the series-Pesticides in the Hydrologic System: Chelsea, Michigan, Ann Arbor Press, $390 \mathrm{p}$.

Lindley, C.E., Stewart, J.T., and Sandstrom, M.W., 1996, Determination of low concentrations of acetochlor in water by automated solid-phase extraction and gas chromatography with mass selective detection: Journal of AOAC International, v. 79, no. 4, p. 962-966.

Madsen, J.E., Sandstrom, M.W., and Zaugg, S.D., 2003, Methods of analysis by the U.S. Geological Survey National Water Quality Laboratory-A method supplement for the determination of fipronil and degradates in water by gas chromatography/mass spectrometry: U.S. Geological Survey Open-File Report 02-462, 11 p.

Mackay, D., Shiu, W., and Ma, K., 1997, Illustrated handbook of physical-chemical properties and environmental fate for organic chemicals: Boca Raton, Florida, Lewis Publishers, v. V, 812 p.

Maloney, T.J., ed., 2005, Quality management system, U.S. Geological Survey National Water Quality Laboratory: U.S. Geological Survey Open-File Report 2005-1263, ver. 1.3, 93 p., accessed November 28, 2005, at URL: http://pubs. water.usgs.gov/ofr20051263.

Munn, M.D., and Gilliom, R.J., 2001, Pesticide toxicity index for freshwater aquatic organisms: U.S. Geological Survey Water-Resources Investigations Report 01-4077, 55 p.

National Marine Fisheries Service (NMFS) 2000. Biological Opinion. Reinitiation of Consultation on Operation of the Federal Columbia River Power System, Including the Juvenile Fish Transportation System, and 19 Bureau of Reclamation Projects in the Columbia River. Northwest Region, December 21, 2000. http://seahorse.nmfs.noaa. gov/pls/pcts-pub/sxn7.pcts upload.summary list biop?p $\underline{\mathrm{id}=14099}$.

Schertz, T.L., Alexander, R. B., and Ohe, D.J., 1991, The computer program Estimate Trend (ESTREND), a system for the detection of trends in water-quality data: U.S. Geological Survey Water-Resources Investigations Report 91-4040, 63 p., accessed August 11, 2005, at URL: http:// pubs.water.usgs.gov/wri914040/. 
State of Washington, 2003, Water quality standards for surface waters of the State of Washington: Washington Administrative Code, Chapter 173-201A WAC, accessed August 22, 2005, at URL: http://www.leg.wa.gov/WAC/ index.cfm?section=173-201A-200\&fuseaction=section.

U.S. Census Bureau, 2000 [2004], United States Census 2000, accessed July 22, 2005, at URL: http://www.census.gov/.

U.S. Department of Agriculture, 2005, National Agriculture Statistics Service, accessed August 19, 2005, at URL: http:// www.nass.usda.gov.

U.S. Environmental Protection Agency, 1979, Methods for the chemical analysis of water and wastes (MCAWW): Cincinnati, Ohio, U.S. Environmental Monitoring Laboratory, Office of Research and Development EPA/600/4-79/020, variously paginated.

U.S. Environmental Protection Agency, 1993, Methods of determination of inorganic substances in environmental samples: Cincinnati, Ohio, U.S. Environmental Monitoring Laboratory, Office of Research and Development EPA/600/ R-93/100, variously paginated.

U.S. Environmental Protection Agency, 2003, Restricted use products (RUP) report, accessed August 23, 2005, at URL: http://www.epa.gov/opprd001/rup/.

U.S. Environmental Protection Agency, 2004a, 2004 Edition of the Drinking Water Standards and Health Advisories: U.S. Environmental Protection Agency, Office of Water, EPA-822-R-04-005, Winter 2004, accessed August 5, 2005, at URL: http://www.epa.gov/waterscience/criteria/drinking/.

U.S. Environmental Protection Agency, 2004b, National recommended water quality criteria: U.S. Environmental Protection Agency, Office of Water and Office of Science and Technology (430T), accessed August 12, 2005, at URL: http://www.epa.gov/waterscience/criteria/wqcriteria.html.

U.S. Environmental Protection Agency, 2005a, ECOTOX database: U.S. Environmental Protection Agency, Office of Research and Development, National Health and Environmental Effects Research Laboratory, Mid-Continent Ecology Division, accessed November 8, 2005 at URL: http://www.epa.gov/ecotox/.

U.S. Environmental Protection Agency, 2005b, Integrated Risk Information System (IRIS) database: U.S. Environmental Protection Agency, Office of Research and Development, National Center for Environmental Assessment, accessed August 19, 2005, at URL: http://www.epa.gov/iris.

Wagner, R.J., Ebbert, J.C., Roberts, L.M., and Ryker, S.J., 1996, Agricultural pesticide applications and observed concentrations in surface waters from four drainage basins in the Central Columbia Plateau, Washington and Idaho, 1993-94: U.S. Geological Survey Water-Resources Investigations Report 95-4285, 50 p., accessed August 22, 2005, at URL: http://pubs.er.usgs.gov/pubs/wri/wri954285.
Walters, K.L., and Grolier, M.J., 1960, Geology and groundwater resources of the Columbia Basin Project area, Washington: Olympia, Washington, Washington Division of Water Resources, Water Supply Bulletin 8, v. 1, 542 p.

Washington Agricultural Statistics Service, 2005, 2004 Washington Annual Bulletin: Olympia, Washington, 143 p.

Wilde, F.D., ed., 2004, Cleaning of equipment for water sampling (ver. 2.0): U.S. Geological Survey Techniques of Water-Resources Investigations, book 9, chap. A3, accessed July 19, 2005, at URL: http://pubs.water.usgs.gov/twri9A3/.

Wilde, F.D., Radtke, D.B., Gibs, Jacob, and Iwatsubo, R.T., eds., 1999a, Collection of water samples: U.S. Geological Survey Techniques of Water-Resources Investigations, book 9, chap. A4, accessed July 15, 2005, at URL: http://pubs. water.usgs.gov/twri9A4/.

Wilde, F.D., Schertz, T.L., and Radtke, D.B., 1999b, Quality control samples: U.S. Geological Survey Techniques of Water-Resources Investigations, book 9, chap. A4, section 4.3, accessed July 25, 2005, at URL: http://pubs.water.usgs. gov/twri9A4/.

Wilde, F.D., Radtke, D.B., Gibs, Jacob, and Iwatsubo, R.T., eds., 2004, Processing of water samples (ver. 2.1): U.S. Geological Survey Techniques of Water-Resources Investigations, book 9, chap. A5, accessed July 15, 2005, at URL: http://pubs.water.usgs.gov/twri9A5/.

Williamson, A.K., Munn, M.D., Ryker, S.J., Wagner, R.J., Ebbert, J.C., and Vanderpool, A.M., 1998, Water quality in the Central Columbia Plateau, Washington and Idaho, 1992-95: U.S. Geological Survey Circular 1144, 35 p., accessed August 15, 2005, at URL: http://pubs.water.usgs. gov/circ1144.

Winter, T.C., Harvey, J.W., Franke, O.L., and Alley, W.M., 1998, Ground water and surface water-A single resource: U.S. Geological Survey Circular 1139, 79 p., accessed October 13, 2005, at URL: http://pubs.water.usgs.gov/ circ1139.

Zaugg, S.D., Sandstrom, M.W., Smith, S.G., and Fehlberg, K.M., 1995, Methods of analysis by the U.S. Geological Survey National Water Quality Laboratory-Determination of pesticides in water by C-18 solid-phase extraction and capillary-column gas chromatography/mass spectrometry with selected-ion monitoring: U.S. Geological Survey Open-File Report 95-181, 60 p., accessed July 14, 2005, at URL: http://nwql.usgs.gov/Public/pubs/OFR95-181/ OFR95-181.html 
Table 16. Concentrations and precision data for pesticide replicate samples, Columbia Basin Project, Washington, July 2002 to October 2004.

[Pesticide target analyte: CIAT, 2-chloro-4-isopropylamino-6-amino-s-triazine; OIET, 2-hydroxy-4-isopropylamino-6-ethylamino-s-triazine.

Abbreviations: $\mu \mathrm{g} / \mathrm{L}$, microgram per liter; $\mathrm{M}$, presence of material verified, but not quantified; ${ }^{\mathrm{E}}$, because recovery or variation in recovery was outside the acceptable range, compound is qualified with an E-code (estimated) or concentration reported is less than laboratory reporting level and is qualified as estimated; $<$, less than; -, no data]

\begin{tabular}{|c|c|c|c|c|c|}
\hline Pesticide target analyte & $\begin{array}{l}\text { Concentration in } \\
\text { replicates } \\
\text { (mg/L) }\end{array}$ & $\begin{array}{l}\text { Percentage } \\
\text { of relative } \\
\text { difference }\end{array}$ & Pesticide target analyte & $\begin{array}{l}\text { Concentration in } \\
\text { replicates } \\
\text { (mg/L) }\end{array}$ & $\begin{array}{l}\text { Percentage } \\
\text { of relative } \\
\text { difference }\end{array}$ \\
\hline \multirow[t]{2}{*}{ 2,4-D methyl ester } & $\begin{array}{r}0.017 \\
.014\end{array}$ & 19 & Chlorpyrifos & $\begin{array}{r}\mathrm{E}_{0.004} \\
\mathrm{E}_{.004}\end{array}$ & 0.0 \\
\hline & $\begin{array}{l}.037 \\
.041\end{array}$ & 10 & DCPA & $\begin{array}{l}.008 \\
.008\end{array}$ & .0 \\
\hline \multirow[t]{2}{*}{$2,4-\mathrm{D}$} & $\begin{array}{l}.29 \\
.29\end{array}$ & .0 & Dicamba & $\begin{array}{l}\text { E.19 } \\
\text { E.13 }\end{array}$ & 38 \\
\hline & $\begin{array}{l}.3 \\
.29\end{array}$ & 3.4 & & $\begin{array}{l}.15 \\
.02 \\
.01\end{array}$ & 67 \\
\hline \multirow[t]{3}{*}{ CIAT } & $\begin{array}{l}<.03 \\
\mathrm{E} .011\end{array}$ & - & Diphenamid & $\begin{array}{l}\mathrm{M} \\
\mathrm{M}\end{array}$ & .0 \\
\hline & $\begin{array}{l}{ }^{\mathrm{E}} .01 \\
{ }^{\mathrm{E}} .01\end{array}$ & .0 & Diuron & $\begin{array}{l}.02 \\
.02\end{array}$ & .0 \\
\hline & $\begin{array}{l}\mathrm{E}_{.01} \\
\mathrm{E}_{.011}\end{array}$ & 9.5 & & $\begin{array}{l}\mathrm{E}_{.01} \\
\mathrm{E}_{.01}\end{array}$ & .0 \\
\hline OIET & $\begin{array}{l}\mathrm{E}_{.009} \\
\mathrm{E}_{.007}\end{array}$ & 25 & ЕРTC & $\begin{array}{l}.033 \\
.032\end{array}$ & 3.1 \\
\hline Alachlor & $\begin{array}{l}\mathrm{E} .004 \\
<.005\end{array}$ & - & Linuron & $\begin{array}{l}\mathrm{E} .014 \\
\mathrm{E} .013\end{array}$ & 7.4 \\
\hline \multirow[t]{3}{*}{ Atrazine } & $\begin{array}{l}.011 \\
.023\end{array}$ & 71 & Metolachlor & $\begin{array}{l}{ }^{\mathrm{E}_{.0}} \\
{ }^{\mathrm{E}} .01\end{array}$ & .0 \\
\hline & $\begin{array}{l}.02 \\
.019\end{array}$ & 5.1 & Metribuzin & $\begin{array}{l}\mathrm{E} .005 \\
\mathrm{E} .005\end{array}$ & .0 \\
\hline & $\begin{array}{l}.01 \\
.019\end{array}$ & 62 & Nicosulfuron & $\begin{array}{l}\mathrm{E}_{.01}^{.000} \\
\mathrm{E}_{.01}\end{array}$ & .0 \\
\hline Azinphos-methyl & $\begin{array}{l}\mathrm{E} .018 \\
\mathrm{E} .019\end{array}$ & 5.4 & Simazine & $\begin{array}{l}.01 \\
.01\end{array}$ & .0 \\
\hline Bentazon & $\begin{array}{l}{ }^{\mathrm{E}} .05 \\
\mathrm{E}_{.05} \\
\mathrm{E}_{.02} \\
{ }^{\mathrm{E}} .02\end{array}$ & $\begin{array}{l}.0 \\
.0\end{array}$ & Terbacil & $\begin{array}{l}\mathrm{E} .022 \\
\mathrm{E} .021\end{array}$ & 4.7 \\
\hline
\end{tabular}

Table 17. Percentage of mean recoveries from field-matrix-pesticide analyses, Columbia Basin Project, Washington, July 2002 to October 2004.

[Abbreviations: M, presence of material verified, but not quantified; -, no data]

\begin{tabular}{|c|c|c|c|c|c|}
\hline Pesticide target analyte & $\begin{array}{l}\text { Percentage of } \\
\text { mean recovery }\end{array}$ & $\begin{array}{l}\text { Number of } \\
\text { samples }\end{array}$ & Pesticide target analyte & $\begin{array}{l}\text { Percentage of } \\
\text { mean recovery }\end{array}$ & $\begin{array}{l}\text { Number of } \\
\text { samples }\end{array}$ \\
\hline \multicolumn{3}{|c|}{$\begin{array}{l}\text { Gas Chromatography/Mass Spectrometry } \\
\text { analytical data }\end{array}$} & \multicolumn{3}{|c|}{$\begin{array}{c}\text { Gas Chromatography/Mass Spectrometry } \\
\text { analytical data-Continued }\end{array}$} \\
\hline Acetochlor & 110 & 1 & CIAT & 33 & 1 \\
\hline Alachlor & 112 & 1 & DCPA & 101 & 1 \\
\hline Atrazine & 125 & 1 & $4,4^{\prime}-\mathrm{DDE}$ & 53 & 1 \\
\hline Benfluralin & 105 & 1 & Dieldrin & 86 & 1 \\
\hline Butylate & 98 & 1 & 2,6-Diethylanaline & 70 & 1 \\
\hline Carbyl & 36 & 1 & Disulfoton & 53 & 1 \\
\hline Carbofuran & 145 & 1 & EPTC & 92 & 1 \\
\hline Chlorpyrifos & 99 & 1 & Ethalfluralin & 121 & 1 \\
\hline Cyanazine & 133 & 1 & Ethoprop & 91 & 1 \\
\hline
\end{tabular}


Table 17. Percentage of mean recoveries from field-matrix-pesticide analyses, Columbia Basin Project, Washington, July 2002 to 0 ctober $2004-$ Continued.

[Abbreviations: M, presence of material verified, but not quantified; -, no data]

\begin{tabular}{|c|c|c|}
\hline Pesticide target analyte & $\begin{array}{l}\text { Percentage of } \\
\text { mean recovery }\end{array}$ & $\begin{array}{l}\text { Number of } \\
\text { samples }\end{array}$ \\
\hline \multicolumn{3}{|c|}{$\begin{array}{c}\text { Gas Chromatography/Mass Spectrometry } \\
\text { analytical data-Continued }\end{array}$} \\
\hline Fipronil & 166 & 1 \\
\hline Fipronil sulfide & 121 & 1 \\
\hline Fipronil sulfone & 108 & 1 \\
\hline Fonos & 94 & 1 \\
\hline alpha-HCH & 92 & 1 \\
\hline gamma-HCH & 92 & 1 \\
\hline Linuron & 97 & 1 \\
\hline Malathion & 113 & 1 \\
\hline Methyl parathion & 164 & 1 \\
\hline Metolachlor & 114 & 1 \\
\hline Metribuzin & 78 & 1 \\
\hline Molinate & 88 & 1 \\
\hline Napropamide & 90 & 1 \\
\hline Parathion & 171 & 1 \\
\hline Pebulate & 93 & 1 \\
\hline Pendimethalin & 116 & 1 \\
\hline cis-Permethrin & 55 & 1 \\
\hline Phorate & 77 & 1 \\
\hline Prometon & 116 & 1 \\
\hline Propyzamide & 95 & 1 \\
\hline Propachlor & 112 & 1 \\
\hline Propanil & 121 & 1 \\
\hline Propargite & 213 & 1 \\
\hline Simazine & 99 & 1 \\
\hline Tebuthiuron & 151 & 1 \\
\hline Terbacil & 79 & 1 \\
\hline Terbufos & 80 & 1 \\
\hline Thiobencarb & 93 & 1 \\
\hline Triallate & 92 & 1 \\
\hline Trifluralin & 108 & 1 \\
\hline
\end{tabular}

High-Performance Liquid Chromatography/Mass Spectrometry analytical data

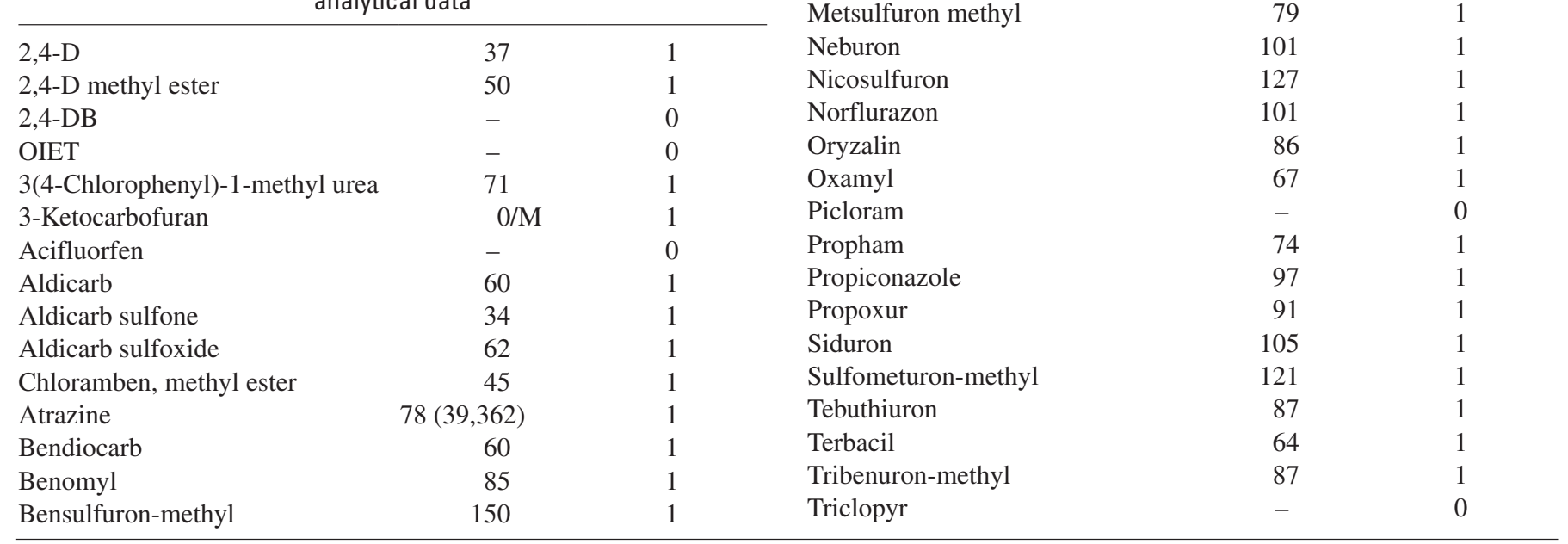


Table 18. Pesticide concentrations analyzed by gas chromatography/mass spectrometry and high-performance liquid chromatography/mass spectrometry, Columbia Basin Project, Washington, July 2002 to October 2004.

[GC/MS, analysis by gas chromatography/mass spectrometry; HPLC/MS, analysis by high-performance liquid chromatography/mass spectrometry. Abbreviations: ${ }^{\mathrm{E}}$, because recovery or variation in recovery was outside the acceptable range, compound is qualified with an E-code (estimated) or concentration reported is less than laboratory reporting level and is qualified as estimated; $<$, less than]

\begin{tabular}{|c|c|c|c|c|c|c|c|c|}
\hline \multirow{3}{*}{ Sampling site } & \multirow{3}{*}{ Date } & \multirow{3}{*}{ Time } & \multicolumn{2}{|c|}{ Atrazine } & \multicolumn{2}{|c|}{ CIAT } & \multicolumn{2}{|c|}{ Tebuthiuron } \\
\hline & & & GC/MS & HPLC/MS & GC/MS & HPLC/MS & GC/MS & HPLC/MS \\
\hline & & & 39632 & 39632 & 4040 & 4040 & 82670 & 82670 \\
\hline \multicolumn{9}{|c|}{ Crab Creek } \\
\hline 12472600 & $07-30-02$ & 1020 & 0.021 & $\mathrm{E}_{0.013}$ & $\mathrm{E}_{0.019}$ & $\mathrm{E}_{0.012}$ & $<0.02$ & $<0.032$ \\
\hline 12472600 & $09-24-02$ & 1100 & .014 & ${ }^{\mathrm{E}} .008$ & ${ }^{\mathrm{E}} .013$ & ${ }^{\mathrm{E}} .009$ & $<.02$ & $<.032$ \\
\hline 12472600 & $02-05-03$ & 1120 & .016 & .01 & $\mathrm{E}_{.014}$ & ${ }^{\mathrm{E}} .008$ & $<.02$ & $<.032$ \\
\hline 12472600 & $04-09-03$ & 0930 & .015 & E.006 & E.009 & E.007 & $<.02$ & $<.032$ \\
\hline 12472600 & $05-07-03$ & 0940 & .023 & .015 & ${ }^{\mathrm{E}} .007$ & ${ }^{\mathrm{E}} .007$ & $<.02$ & $<.032$ \\
\hline 12472600 & 07-01-03 & 1400 & .019 & ${ }^{\mathrm{E}} .009$ & ${ }^{\mathrm{E}} .011$ & ${ }^{\mathrm{E}} .006$ & $<.02$ & $<.032$ \\
\hline 12472600 & $10-06-03$ & 1350 & .014 & ${ }^{\mathrm{E}} .009$ & ${ }^{\mathrm{E}} .004$ & ${ }^{\mathrm{E}} .009$ & $<.02$ & $<.032$ \\
\hline 12472600 & $02-03-04$ & 1330 & .017 & ${ }^{\mathrm{E}} .005$ & ${ }^{\mathrm{E}} .014$ & $<.028$ & $<.02$ & $<.032$ \\
\hline 12472600 & 04-06-04 & 1310 & .016 & ${ }^{\mathrm{E}} .008$ & ${ }^{\mathrm{E}} .011$ & ${ }^{\mathrm{E}} .007$ & $<.02$ & $<.032$ \\
\hline 12472600 & $06-08-04$ & 1250 & .019 & .01 & ${ }^{\mathrm{E}} .010$ & $<.028$ & $<.02$ & $<.032$ \\
\hline 12472600 & $07-07-04$ & 1320 & .026 & .013 & ${ }^{\mathrm{E}} .012$ & ${ }^{\mathrm{E}} .008$ & $<.02$ & $<.032$ \\
\hline 12472600 & $10-05-04$ & 1310 & .018 & E.006 & $\mathrm{E}_{.010}$ & E.005 & $<.02$ & E.004 \\
\hline \multicolumn{9}{|c|}{ Lind Coulee } \\
\hline 12471400 & $07-30-02$ & 1345 & 0.008 & $\mathrm{E}_{0.004}$ & $\mathrm{E}_{0.005}$ & $<0.028$ & $<0.02$ & $<0.032$ \\
\hline 12471400 & $09-24-02$ & 1400 & .009 & ${ }^{\mathrm{E}} .004$ & ${ }^{\mathrm{E}} .006$ & ${ }^{\mathrm{E}} .004$ & $<.02$ & $<.032$ \\
\hline 12471400 & $02-05-03$ & 1440 & .011 & ${ }^{\mathrm{E}} .006$ & ${ }^{\mathrm{E}} .008$ & ${ }^{\mathrm{E}} .005$ & $<.02$ & $<.032$ \\
\hline 12471400 & 04-09-03 & 1520 & $<.007$ & $<.009$ & $<.006$ & $<.028$ & $<.02$ & $<.032$ \\
\hline 12471400 & 06-07-03 & 1320 & $<.007$ & $<.009$ & $<.006$ & $<.028$ & $<.02$ & $<.032$ \\
\hline 12471400 & $07-02-03$ & 1430 & .009 & ${ }^{\mathrm{E}} .005$ & ${ }^{\mathrm{E}} .004$ & $<.028$ & $<.02$ & $<.032$ \\
\hline 12471400 & $10-07-03$ & 1440 & .009 & ${ }^{\mathrm{E}} .004$ & ${ }^{\mathrm{E}} .003$ & ${ }^{\mathrm{E}} .003$ & $<.02$ & $<.032$ \\
\hline 12471400 & 02-04-04 & 1350 & .01 & $<.009$ & ${ }^{\mathrm{E}} .009$ & $<.028$ & $<.02$ & $<.032$ \\
\hline 12471400 & 04-07-04 & 1410 & .011 & ${ }^{\mathrm{E}} .004$ & $<.006$ & $<.028$ & $<.02$ & $<.032$ \\
\hline 12471400 & 06-09-04 & 1310 & .01 & ${ }^{\mathrm{E}} .003$ & ${ }^{\mathrm{E}} .005$ & $<.028$ & $<.02$ & $<.032$ \\
\hline 12471400 & $07-08-04$ & 1240 & .011 & ${ }^{\mathrm{E}} .004$ & ${ }^{\mathrm{E}} .005$ & $<.028$ & $<.02$ & $<.032$ \\
\hline 12471400 & 10-06-04 & 1410 & .012 & $<.008$ & ${ }^{\mathrm{E}} .004$ & $<.028$ & $<.02$ & $<.032$ \\
\hline \multicolumn{9}{|c|}{ Red Rock Coulee } \\
\hline 12472520 & $07-29-02$ & 1450 & 0.018 & $\mathrm{E}_{0.011}$ & $\mathrm{E}_{0.011}$ & $\mathrm{E}_{0.008}$ & $<0.02$ & $<0.032$ \\
\hline 12472520 & $09-23-02$ & 1310 & .017 & ${ }^{\mathrm{E}} .006$ & ${ }^{\mathrm{E}} .011$ & ${ }^{\mathrm{E}} .005$ & $<.02$ & $<.032$ \\
\hline 12472520 & $02-04-03$ & 1350 & .019 & .012 & ${ }^{\mathrm{E}} .015$ & ${ }^{\mathrm{E}} .009$ & $<.02$ & $<.032$ \\
\hline 12472520 & $04-09-03$ & 1150 & .021 & ${ }^{\mathrm{E}} .008$ & ${ }^{\mathrm{E}} .015$ & ${ }^{\mathrm{E}} .007$ & $<.02$ & $<.032$ \\
\hline 12472520 & $05-06-03$ & 1310 & .032 & ${ }^{\mathrm{E}} .030$ & ${ }^{\mathrm{E}} .008$ & ${ }^{\mathrm{E}} .012$ & $<.02$ & $<.032$ \\
\hline 12472520 & $07-02-03$ & 1020 & .019 & .012 & ${ }^{\mathrm{E}} .009$ & ${ }^{\mathrm{E}} .006$ & $<.02$ & $<.032$ \\
\hline 12472520 & $02-04-04$ & 0910 & .018 & E.006 & E.013 & $<.028$ & $<.02$ & $<.032$ \\
\hline 12472520 & 04-07-04 & 0910 & .019 & .011 & ${ }^{\mathrm{E}} .011$ & $<.028$ & $<.02$ & $<.032$ \\
\hline 12472520 & 06-09-04 & 0810 & .023 & .011 & ${ }^{\mathrm{E}} .011$ & $<.028$ & $<.02$ & $<.032$ \\
\hline 12472520 & 07-08-04 & 0830 & .029 & .017 & ${ }^{\mathrm{E}} .010$ & ${ }^{\mathrm{E}} .007$ & $<.02$ & $<.032$ \\
\hline 12472520 & $10-06-04$ & 0930 & .018 & ${ }^{\mathrm{E}} .006$ & ${ }^{\mathrm{E}} .009$ & ${ }^{\mathrm{E}} .004$ & $<.02$ & $<.032$ \\
\hline \multicolumn{9}{|c|}{ Sand Hollow } \\
\hline 12464606 & $07-29-02$ & 1150 & 0.009 & $\mathrm{E}_{0.005}$ & $\mathrm{E}_{0.008}$ & $<0.005$ & $<0.02$ & $<0.032$ \\
\hline 12464607 & $09-23-02$ & 1100 & .013 & E.004 & E.013 & E.005 & $<.02$ & $<.032$ \\
\hline 12464607 & $02-04-03$ & 1050 & .029 & .021 & $\mathrm{E}_{0} .036$ & ${ }^{\mathrm{E}} .021$ & $<.02$ & $<.032$ \\
\hline 12464607 & 04-07-03 & 1050 & .008 & $<.009$ & ${ }^{\mathrm{E}} .005$ & ${ }^{\mathrm{E}} .004$ & $<.02$ & $<.032$ \\
\hline 12464607 & $05-06-03$ & 1010 & $<.007$ & ${ }^{\mathrm{E}} .005$ & $<.006$ & ${ }^{\mathrm{E}} .006$ & $<.02$ & $<.032$ \\
\hline 12464607 & $07-01-03$ & 1020 & .014 & ${ }^{\mathrm{E}} .007$ & ${ }^{\mathrm{E}} .012$ & ${ }^{\mathrm{E}} .007$ & $<.02$ & $<.032$ \\
\hline 12464607 & $10-06-03$ & 1010 & .01 & ${ }^{\mathrm{E}} .005$ & ${ }^{\mathrm{E}} .005$ & ${ }^{\mathrm{E}} .006$ & $<.02$ & $<.032$ \\
\hline 12464607 & $02-03-04$ & 0920 & .026 & E.007 & ${ }^{\mathrm{E}} .029$ & ${ }^{\mathrm{E}} .005$ & $<.02$ & $<.032$ \\
\hline 12464607 & 04-06-04 & 0920 & .013 & ${ }^{\mathrm{E}} .004$ & ${ }^{\mathrm{E}} .009$ & ${ }^{\mathrm{E}} .005$ & $<.02$ & $<.032$ \\
\hline 12464607 & 06-08-04 & 0840 & .011 & ${ }^{\mathrm{E}} .005$ & ${ }^{\mathrm{E}} .008$ & $<.028$ & $<.02$ & $<.032$ \\
\hline 12464607 & 07-07-04 & 0930 & .01 & ${ }^{\mathrm{E}} .005$ & ${ }^{\mathrm{E}} .008$ & $<.028$ & $<.02$ & $<.032$ \\
\hline 12464607 & $10-05-04$ & 0930 & .015 & ${ }^{\mathrm{E}} .004$ & ${ }^{\mathrm{E}} .009$ & ${ }^{\mathrm{E}} .004$ & $<.02$ & $<.032$ \\
\hline Total sample & & & 47 & & 47 & & 47 & \\
\hline Total $<$ & & & 2 & & 3 & & 46 & \\
\hline Total hits & & & 41 & & 29 & & 0 & \\
\hline Negligent hit/n & & & 4 & & 15 & & 1 & \\
\hline Significant hits & & & 0 & & 0 & & 0 & \\
\hline Median percen & difference & & 79 & & 79 & & & \\
\hline
\end{tabular}


Table 18. Pesticide concentrations analyzed by gas chromatography/mass spectrometry and high-performance liquid chromatography/ mass spectrometry, Columbia Basin Project, Washington, July 2002 to October 2004.—Continued

[GC/MS, analysis by gas chromatography/mass spectrometry; HPLC/MS, analysis by high-performance liquid chromatography/mass spectrometry. Abbreviations: ${ }^{\mathrm{E}}$, because recovery or variation in recovery was outside the acceptable range, compound is qualified with an E-code (estimated) or concentration reported is less than laboratory reporting level and is qualified as estimated; <, less than]

\begin{tabular}{|c|c|c|c|c|c|c|c|c|c|c|}
\hline \multirow{3}{*}{ Sampling site } & \multirow{3}{*}{ Date } & \multirow{3}{*}{ Time } & \multicolumn{2}{|c|}{ Carbaryl } & \multicolumn{2}{|c|}{ Carbofuran } & \multicolumn{2}{|c|}{ Linuron } & \multicolumn{2}{|c|}{ Terbacil } \\
\hline & & & GC/MS & HPLC/MS & GC/MS & HPLC/MS & GC/MS & HPLC/MS & GC/MS & HPLC/MS \\
\hline & & & P82680 & P49310 & P82674 & P49309 & P82666 & P38478 & P82665 & P04032 \\
\hline \multicolumn{11}{|c|}{ Crab Creek } \\
\hline 12472600 & $07-30-02$ & 1020 & ${ }^{\mathrm{E}} .005$ & $<.03$ & $<.020$ & $<.006$ & $<.035$ & $<.01$ & $<.034$ & $<.010$ \\
\hline 12472600 & 09-24-02 & 1100 & $<.041$ & $<.03$ & $<.020$ & $<.006$ & $<.035$ & $<.01$ & $<.034$ & $<.010$ \\
\hline 12472600 & 02-05-03 & 1120 & $<.041$ & $<.03$ & $<.020$ & $<.006$ & $<.035$ & $<.01$ & $<.034$ & $<.010$ \\
\hline 12472600 & 04-09-03 & 0930 & $<.041$ & $<.03$ & $<.020$ & $<.006$ & $<.035$ & $<.01$ & ${ }^{\mathrm{E}} .061$ & ${ }^{\mathrm{E}} .031$ \\
\hline 12472600 & $05-07-03$ & 0940 & $<.041$ & $<.03$ & $<.020$ & $<.006$ & $<.035$ & $<.01$ & ${ }^{\mathrm{E}} .033$ & ${ }^{\mathrm{E}} .025$ \\
\hline 12472600 & 07-01-03 & 1400 & $<.041$ & $<.03$ & $<.020$ & $<.006$ & $<.035$ & $<.01$ & ${ }^{\mathrm{E}} .026$ & $<.010$ \\
\hline 12472600 & $10-06-03$ & 1350 & $<.041$ & $<.03$ & $<.020$ & $<.006$ & $<.035$ & $<.01$ & $<.034$ & ${ }^{\mathrm{E}} .006$ \\
\hline 12472600 & 02-03-04 & 1330 & $<.041$ & $<.03$ & $<.020$ & $<.006$ & $<.035$ & $<.01$ & $<.034$ & $<.010$ \\
\hline 12472600 & 04-06-04 & 1310 & $<.041$ & $<.03$ & $<.020$ & $<.006$ & $<.035$ & $<.01$ & ${ }^{\mathrm{E}} .016$ & $<.010$ \\
\hline 12472600 & $06-08-04$ & 1250 & $<.041$ & $<.03$ & $<.020$ & $<.006$ & ${ }^{\mathrm{E}} .013$ & $<.01$ & ${ }^{\mathrm{E}} .021$ & $<.010$ \\
\hline 12472600 & 07-07-04 & 1320 & ${ }^{\mathrm{E}} .009$ & $<.03$ & $<.020$ & $<.006$ & $<.035$ & $<.01$ & ${ }^{\mathrm{E}} .021$ & $<.010$ \\
\hline 12472600 & $10-05-04$ & 1310 & $<.041$ & $<.02$ & $<.020$ & $<.016$ & $<.035$ & $<.01$ & $<.034$ & $<.016$ \\
\hline \multicolumn{11}{|c|}{ Lind Coulee } \\
\hline 12471400 & $07-30-02$ & 1345 & $<.041$ & $<.03$ & $<.020$ & $<.006$ & $<.035$ & $<.01$ & $<.034$ & $<.010$ \\
\hline 12471400 & $09-24-02$ & 1400 & $<.041$ & $<.03$ & $<.020$ & $<.006$ & ${ }^{\mathrm{E}} .006$ & $<.01$ & $<.034$ & $<.010$ \\
\hline 12471400 & $02-05-03$ & 1440 & $<.041$ & $<.03$ & $<.020$ & $<.006$ & $<.035$ & $<.01$ & $<.034$ & $<.010$ \\
\hline 12471400 & 04-09-03 & 1520 & $<.041$ & $<.03$ & $<.020$ & $<.006$ & $<.035$ & $<.01$ & $<.034$ & $<.010$ \\
\hline 12471400 & $06-07-03$ & 1320 & $<.041$ & $<.03$ & $<.020$ & $<.006$ & $<.035$ & $<.01$ & $<.034$ & $<.010$ \\
\hline 12471400 & $07-02-03$ & 1430 & $<.041$ & $<.03$ & $<.020$ & $<.006$ & $<.035$ & $<.01$ & $<.034$ & $<.010$ \\
\hline 12471400 & $10-07-03$ & 1440 & $<.041$ & $<.03$ & $<.020$ & $<.006$ & $<.035$ & $<.01$ & $<.034$ & $<.010$ \\
\hline 12471400 & 02-04-04 & 1350 & $<.041$ & $<.03$ & $<.020$ & $<.006$ & $<.035$ & $<.01$ & $<.034$ & $<.010$ \\
\hline 12471400 & 04-07-04 & 1410 & $<.041$ & $<.03$ & $<.020$ & $<.006$ & $<.035$ & $<.01$ & $<.034$ & $<.010$ \\
\hline 12471400 & 06-09-04 & 1310 & $<.041$ & $<.03$ & $<.020$ & $<.006$ & ${ }^{\mathrm{E}} .013$ & $<.01$ & $<.034$ & $<.010$ \\
\hline 12471400 & 07-08-04 & 1240 & $<.041$ & $<.03$ & $<.020$ & $<.006$ & $<.035$ & $<.01$ & $<.034$ & $<.010$ \\
\hline 12471400 & $10-06-04$ & 1410 & $<.041$ & $<.02$ & $<.020$ & $<.016$ & $<.035$ & $<.01$ & $<.034$ & $<.016$ \\
\hline \multicolumn{11}{|c|}{ Red Rock Coulee } \\
\hline 12472520 & 07-29-02 & 1450 & $<.041$ & $<.03$ & $<.020$ & $<.006$ & $<.035$ & $<.01$ & $<.034$ & $<.010$ \\
\hline 12472520 & 09-23-02 & 1310 & $<.041$ & $<.03$ & $<.020$ & $<.006$ & $<.035$ & $<.01$ & ${ }^{\mathrm{E}} .014$ & $<.010$ \\
\hline 12472520 & $02-04-03$ & 1350 & $<.041$ & $<.03$ & $<.020$ & $<.006$ & $<.035$ & $\mathrm{E}_{.01}$ & $<.034$ & ${ }^{\mathrm{E}} .005$ \\
\hline 12472520 & 04-09-03 & 1150 & $<.041$ & $<.03$ & $<.020$ & $<.006$ & $<.035$ & $<.01$ & ${ }^{\mathrm{E}} .044$ & ${ }^{\mathrm{E}} .020$ \\
\hline 12472520 & $05-06-03$ & 1310 & $<.041$ & $<.03$ & $<.020$ & $<.006$ & $<.035$ & $<.01$ & ${ }^{\mathrm{E}} .075$ & ${ }^{\mathrm{E}} .090$ \\
\hline 12472520 & $07-02-03$ & 1020 & $<.041$ & $<.03$ & $<.020$ & $<.006$ & $<.035$ & $<.01$ & ${ }^{\mathrm{E}} .020$ & ${ }^{\mathrm{E}} .010$ \\
\hline 12472520 & 02-04-04 & 0910 & $<.041$ & $<.03$ & $<.020$ & $<.006$ & $<.035$ & $<.01$ & $<.034$ & ${ }^{\mathrm{E}} .006$ \\
\hline 12472520 & 04-07-04 & 0910 & $<.041$ & $<.03$ & $<.020$ & $<.006$ & $<.035$ & $<.01$ & ${ }^{\mathrm{E}} .040$ & $<.027$ \\
\hline 12472520 & 06-09-04 & 0810 & $<.041$ & $<.03$ & $<.020$ & $<.006$ & ${ }^{\mathrm{E}} .014$ & $<.01$ & ${ }^{\mathrm{E}} .050$ & $<.010$ \\
\hline 12472520 & 07-08-04 & 0830 & $<.041$ & $<.03$ & $<.020$ & $<.006$ & $<.035$ & $<.01$ & ${ }^{\mathrm{E}} .011$ & $<.010$ \\
\hline 12472520 & $10-06-04$ & 0930 & $<.041$ & $<.02$ & $<.020$ & $<.016$ & $<.035$ & $<.01$ & $<.034$ & $<.016$ \\
\hline \multicolumn{11}{|c|}{ Sand Hollow } \\
\hline 12464606 & 07-29-02 & 1150 & $\mathrm{E}_{0.005}$ & $<0.03$ & $<0.020$ & $<0.006$ & $<0.035$ & $<0.01$ & $\mathrm{E}_{0.071}$ & $\mathrm{E}_{0.042}$ \\
\hline 12464607 & 09-23-02 & 1100 & $<.041$ & $<.03$ & $<.020$ & $<.006$ & $<.035$ & $<.01$ & ${ }^{\mathrm{E}} .106$ & .051 \\
\hline 12464607 & $02-04-03$ & 1050 & $<.041$ & $<.03$ & $<.020$ & $<.006$ & $<.035$ & $<.01$ & ${ }^{\mathrm{E}} .157$ & E.085 \\
\hline 12464607 & 04-07-03 & 1050 & $<.041$ & $<.03$ & $<.020$ & $<.006$ & $<.035$ & $<.01$ & $\mathrm{E}_{1.01}$ & $\mathrm{E}_{1.35}$ \\
\hline 12464607 & $05-06-03$ & 1010 & ${ }^{\mathrm{E}} .009$ & E.01 & $<.020$ & $<.006$ & $<.035$ & $<.01$ & ${ }^{\mathrm{E}} .070$ & ${ }^{\mathrm{E}} .069$ \\
\hline 12464607 & $07-01-03$ & 1020 & $<.041$ & $<.03$ & $<.020$ & $<.006$ & $<.035$ & $<.01$ & E.237 & E.176 \\
\hline 12464607 & $10-06-03$ & 1010 & $<.041$ & $<.03$ & $<.020$ & $<.006$ & $<.035$ & ${ }^{\mathrm{E}} .01$ & ${ }^{\mathrm{E}} .047$ & ${ }^{\mathrm{E}} .044$ \\
\hline 12464607 & 02-03-04 & 0920 & $<.041$ & $<.03$ & $<.020$ & $<.006$ & $<.035$ & $<.01$ & ${ }^{\mathrm{E}} .259$ & $\mathrm{E}^{\mathrm{E}} 123$ \\
\hline 12464607 & 04-06-04 & 0920 & $<.041$ & $<.03$ & $<.020$ & $<.006$ & $<.035$ & $<.01$ & ${ }^{\mathrm{E}} .053$ & $<.019$ \\
\hline 12464607 & $06-08-04$ & 0840 & ${ }^{\mathrm{E}} .070$ & ${ }^{\mathrm{E}} .01$ & $<.020$ & $<.006$ & ${ }^{\mathrm{E}} .007$ & $<.01$ & ${ }^{\mathrm{E}} .088$ & ${ }^{\mathrm{E}} .030$ \\
\hline 12464607 & $07-07-04$ & 0930 & ${ }^{\mathrm{E}} .031$ & ${ }^{\mathrm{E}} .01$ & $<.020$ & $<.006$ & $<.035$ & $<.01$ & ${ }^{\mathrm{E}} .075$ & $<.032$ \\
\hline 12464607 & $10-05-04$ & 0930 & $<.041$ & $<.02$ & $<.020$ & $<.016$ & $<.035$ & $<.01$ & ${ }^{\mathrm{E}} .051$ & ${ }^{\mathrm{E}} .033$ \\
\hline Total sample & & & 47 & & 47 & & 47 & & 47 & \\
\hline Total $<$ & & & 41 & & 47 & & 40 & & 19 & \\
\hline Total hits & & & 3 & & 0 & & 0 & & 15 & \\
\hline Negligent hit & /miss & & 3 & & 0 & & 7 & & 5 & \\
\hline Significant $\mathrm{h}$ & its/miss & & 0 & & 0 & & 0 & & 8 & \\
\hline Median perc & entage differe & e of hits & 56 & & & & & & 39 & \\
\hline
\end{tabular}


Table 19. Registration status of pesticides analyzed, Columbia Basin Project, Washington, July 2002 to October 2004.

[Type of pesticide: F, fungicide; H, herbicide; I, insecticide; S, stimulant. Registered use: Home and (or) commercial]

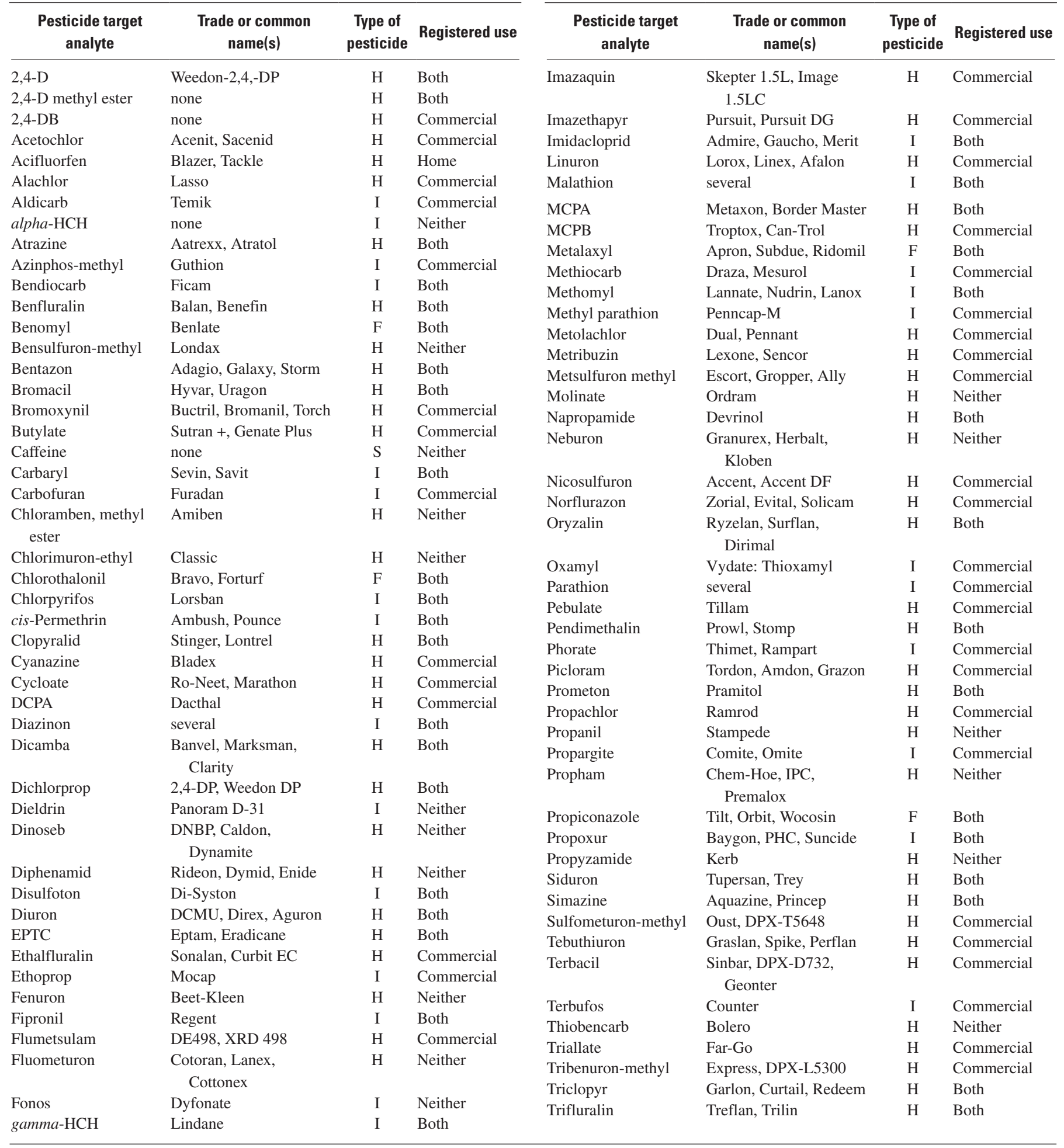


54 Pesticides in Agricultural Irrigation-Return Flow, Columbia Basin Project, Washington, 2002-04

Table 20. Summary of pesticides not detected, Columbia Basin Project, Washington, July 2002 to October 2004.

[Type of pesticide: $\mathrm{H}$, herbicide; I, insecticide; T, transformation product]

\begin{tabular}{|c|c|c|c|c|c|}
\hline Pesticide target analyte & Trade or common name(s) & $\begin{array}{c}\text { Type of } \\
\text { pesticide }\end{array}$ & Pesticide target analyte & Trade or common name(s) & $\begin{array}{c}\text { Type of } \\
\text { pesticide }\end{array}$ \\
\hline 2,6-Diethylanaline & none & $\mathrm{T}$ & Flumetsulam & DE498, XRD 498 & $\mathrm{H}$ \\
\hline urea & & & Fonos & Dyfonate & I \\
\hline 3-Hydroxycarbofuran & none & $\mathrm{T}$ & gamma-HCH & Lindane & I \\
\hline 3-Ketocarbofuran & none & $\mathrm{T}$ & Imazaquin & Skepter $1.5 \mathrm{~L}$, Image $1.5 \mathrm{LC}$ & $\mathrm{H}$ \\
\hline $4,4^{\prime}-\mathrm{DDE}$ & none & $\mathrm{T}$ & Imazethapyr & Pursuit, Pursuit DG & $\mathrm{H}$ \\
\hline Acifluorfen & Blazer, Tackle & $\mathrm{H}$ & МСРВ & Troptox, Can-Trol & $\mathrm{H}$ \\
\hline Aldicarb & Temik & I & Methiocarb & Draza, Mesurol & I \\
\hline Aldicarb sulfone & none & $\mathrm{T}$ & Methyl parathion & Penncap-M & I \\
\hline Aldicarb sulfoxide & none & $\mathrm{T}$ & Metsulfuron methyl & Escort, Gropper, Ally & $\mathrm{H}$ \\
\hline alpha- $\mathrm{HCH}$ & none & $\mathrm{I}$ & Molinate & Ordram & $\mathrm{H}$ \\
\hline Bendiocarb & Ficam & $\mathrm{I}$ & Napropamide & Devrinol & $\mathrm{H}$ \\
\hline Chloramben, methyl ester & Amiben & $\mathrm{H}$ & Phorate & Thimet, Rampart & I \\
\hline Chlorimuron-ethyl & Classic & $\mathrm{H}$ & Picloram & Tordon, Amdon, Grazon & $\mathrm{H}$ \\
\hline cis-Permethrin & Ambush, Pounce & I & Propachlor & Ramrod & $\mathrm{H}$ \\
\hline Cyanazine & Bladex & $\mathrm{H}$ & Propanil & Stampede & $\mathrm{H}$ \\
\hline Cycloate & Ro-Neet, Marathon & $\mathrm{H}$ & Propargite & Comite, Omite & I \\
\hline Desulfinylfipronil & none & $\mathrm{T}$ & Propham & Chem-Hoe, IPC, Premalox & $\mathrm{H}$ \\
\hline Desulfinylfipronil amide & none & $\mathrm{T}$ & Propoxur & Baygon, PHC, Suncide & I \\
\hline Dichlorprop & 2,4-DP, Weedon DP & $\mathrm{H}$ & Propyzamide & Kerb & $\mathrm{H}$ \\
\hline Dieldrin & Panoram D-31 & I & Siduron & Tupersan, Trey & $\mathrm{H}$ \\
\hline Disulfoton & Di-Syston & I & Sulfometuron-methyl & Oust, DPX-T5648 & $\mathrm{H}$ \\
\hline Fenuron & Beet-Kleen & $\mathrm{H}$ & Tebuthiuron & Spike & $\mathrm{H}$ \\
\hline Fipronil & Regent & I & Terbacil & Sinbar & $\mathrm{H}$ \\
\hline Fipronil sulfide & none & $\mathrm{T}$ & Terbufos & Counter & I \\
\hline
\end{tabular}


Manuscript approved for publication, January 6, 2006

Prepared by the U.S. Geological Survey Publishing staff, Tacoma Publishing Services Center,

Bill Gibbs

Debra Grillo

Judy Wayenberg

Bobbie Jo Richey

For more information concerning the research in this report, contact the Director, Washington Water Science Center

U.S. Geological Survey, 1201 Pacific Avenue - Suite 600

Tacoma, Washington, 98402

http://wa.water.usgs.gov 
